\title{
ipen
}

AUTARQUIA ASSOCIADA À UNIVERSIDADE

DE SÃO PAULO

DETERMINAÇÃO DE VOLÁTEIS PRODUZIDOS DURANTE O

PROCESSAMENTO POR RADIAÇÃO EM ERVAS ALIMENTÍCIAS E

MEDICINAIS

DÉBORA CHRISTINA SALUM

Dissertação apresentada como parte dos requisitos para obtenção do Grau de Mestre em Ciências na Área de Tecnologia Nuclear Aplicações

Orientadora:

Dra. Anna Lúcia C.H. Villavicencio

São Paulo

2008 
INSTITUTO DE PESQUISAS ENERGÉTICAS E NUCLEARES

Autarquia associada à Universidade de São Paulo

\section{DETERMINAÇÃO DE VOLÁTEIS PRODUZIDOS DURANTE O PROCESSAMENTO POR RADIAÇÃO EM ERVAS ALIMENTÍCIAS E MEDICINAIS}

DÉBORA CHRISTINA SALUM

Dissertação apresentada como parte dos requisitos para obtenção do Grau de Mestre em Ciências na Área de Tecnologia Nuclear Aplicações

Orientadora:

Dra. Anna Lúcia C.H. Villavicencio 
Ao meu saudoso pai

Renato (In memoriam)

A minha mãe Helena 


\section{AGRADECIMENTOS}

- Agradeço a Deus por ter tornado possível a realização de mais um sonho, pela saúde, força e maravilhosa graça.

- A minha orientadora Dra. Anna Lúcia Villavicencio, a quem ofereço a mais sincera e efusiva admiração.

- Ao Prof. Dr. Eduardo Purgatto, pelo apoio, confiança, dedicação e indispensáveis conhecimentos oferecidos.

- A Dra. Gaianê Sabundjian e a Msc. Margareth Damy pela amizade, incentivo e confiança.

- Ao Instituto de Pesquisas Energéticas e Nucleares e a Faculdade de Ciências Farmacêuticas da Universidade de São Paulo, por terem me proporcionado a oportunidade de me realizar profissionalmente.

- A Hikari Indústria e Comércio pela doação das amostras de especiarias para a realização das análises.

- A engenheira Elizabeth Somessari pela sua disponibilidade e atenção nas irradiações das amostras.

- Aos colegas, Elen, Reginaldo, Michel, Simone, Ingrid, Gustavo, Camilo, Priscila, Renato, Thaise, Fernanda e Vladmir.

- A minha família pelo carinho e apoio irrepreensível. 
"O temor do Senhor é o princípio

da sabedoria”

Pv 1.7 


\title{
DETERMINAÇÃO DE VOLÁTEIS PRODUZIDOS DURANTE O PROCESSAMENTO POR RADIAÇÃO EM ERVAS ALIMENTÍCIAS E MEDICINAIS
}

\author{
Débora Christina Salum
}

\section{RESUMO}

Com o intuito de proteger o alimento de microorganismos patogênicos, como também aumentar a vida de prateleira preservando propriedades sensoriais (ex. odor e paladar), uma vez que essas propriedades são as mais requisitadas pelo consumidor, é necessário analisar a formação dos voláteis de especiarias e ervas medicinais após a irradiação.

O objetivo do presente trabalho foi analisar a formação de voláteis após irradiação de Laurus Cinnamomum, Piper Nigrum, Origanum Vulgare e Myristica Fragans. Possíveis mudanças no odor dessas especiarias através de diferentes doses de radiação foram avaliadas com o intuito de melhorar a aplicação desta tecnologia.

As amostras foram irradiadas em embalagens plásticas em um irradiador de 60Co. Doses de radiação de 0, 5, 10, 15, 20 e 25 kGy foram testadas. Laurus Cinnamomum obteve perda de 56 a 89,5\% de voláteis, quando comparada à amostra não-irradiada. Diferentemente das demais especiarias, a irradiação de Myristica Fragans apresentou aumento de compostos voláteis, com exceção do 4-terpineol. A miristicina (substância tóxica em concentrações altas) apresentou aumento médio de $80 \%$. Origanum Vulgare e Piper Nigrum apresentaram perda de compostos, principalmente quando submetidas à dose de 25kGy. Em geral, os resultados indicaram perda na qualidade sensorial das especiarias. 


\title{
DETERMINATION OF VOLATILES PRODUCED DURING RADIATION PROCESSING IN FOOD AND MEDICINAL HERBS
}

\author{
Débora Christina Salum
}

\begin{abstract}
In order to protect food from pathogenic microorganisms as well as to increase its shelf life while keeping sensorial properties (e.g. odor and taste), once the latter are one of the main properties required by spice buyers, it is necessary to analyze volatile formation from irradiation of medicinal and food herbs.

The aim of the present study was to analyze volatile formation from ${ }^{60} \mathrm{Co}$ irradiation of Laurus Cinnamomum, Piper Nigrum, Origanum Vulgare and Myristica Fragans. Possible changes on the odor of these herbs are evaluated by characterizing different radiation doses and effects on sensorial properties in order to allow better application of irradiation technology.

The samples have been irradiated in plastic packages by making use of a ${ }^{60} \mathrm{Co}$ Gamma irradiator. Irradiation doses of 0, 5, 10, 15, 20 and 25kGy have been tested. For the analysis of the samples, SPME has been applied, while for the analysis of volatile compounds, CG/MS. Spice irradiation has promoted mostly decrease in volatile compounds when doses of 5, 10, 15, 20 and 25kGy were used. For Laurus cinnamomum, the irradiation decreased volatile by nearly $56 \%$ and $89.5 \%$ respectively, comparing to volatile from a sample which has not been previously irradiated.

Differently from other spices analyzed, irradiation on Myristica Fragans has increased volatile compounds except for 4-terpineol. The miristicine (toxic substance when in large quantities, commonly mentioned as narcotic) has increased by nearly $80 \%$. For Origanum Vulgare and Piper Nigrum, significant decrease in volatile compounds have been found, mainly when it comes to 25 kGy irradiation. In general, results indicate loss of sensorial quality of spices.
\end{abstract}




\section{SUMÁRIO}

Página

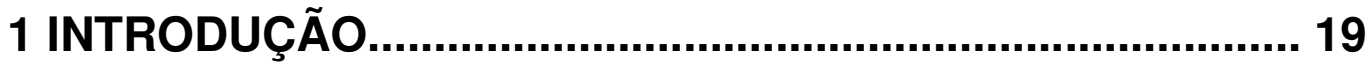

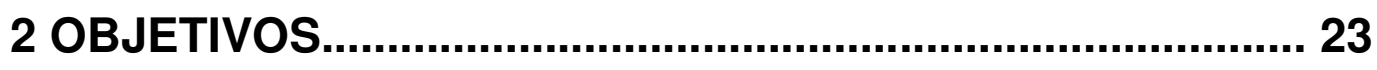

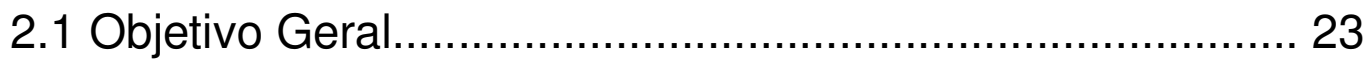

2.2 Objetivos Específicos.................................................. 23

3 REVISÃO DA LITERATURA............................................ 24

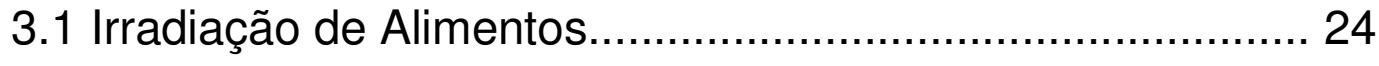

3.1.1 Fontes de Irradiação de Alimentos................................. 29

3.2 Histórico da Irradiação de Alimentos................................. 32

3.3 Irradiação de Alimentos no Mundo.................................... 35

3.4 Legislação.................................................................... 43

3.5 Aceitação do Público .................................................... 45

3.6 Especiarias e Ervas Medicinais...................................... 47

3.7 História das Especiarias.................................................... 56

3.8 Mercado das Especiarias................................................. 59

3.9 Irradiação de Especiarias................................................. 62

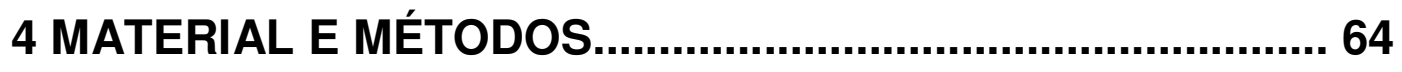

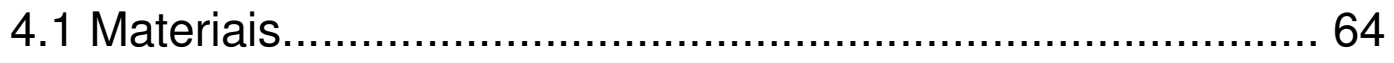




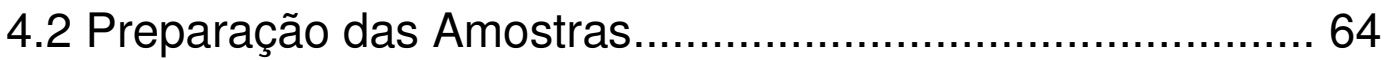

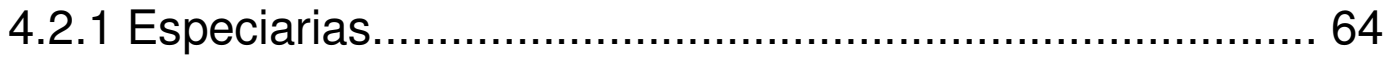

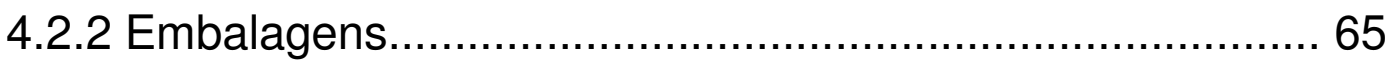

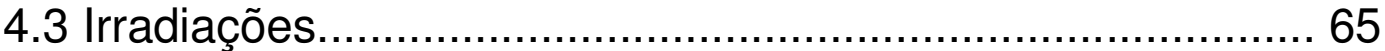

4.4 Técnica de Microextração em Fase Sólida (SPME -

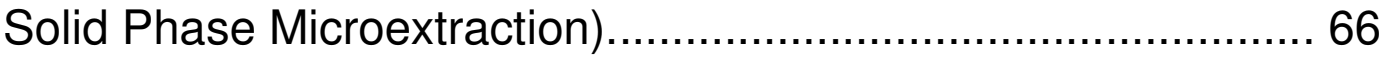

4.5 Determinação de Voláteis por Cromatografia Gasosa

acoplada a um Espectrômetro de Massa (CG/MS).................... 69

4.6 Análise Estatística - Análise de Componentes

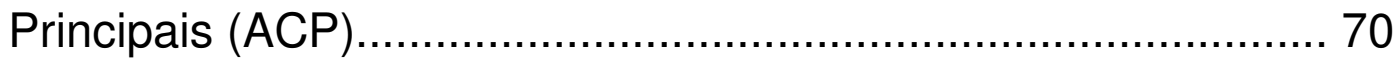

5 RESULTADOS E DISCUSSÃO........................................... 72

5.1 Cinnamomum Zeylanicum BLUME - (Canela)..................... 72

5.2 Myristica Fragans - (Noz-moscada).................................. 82

5.3 Origanum Vulgare - (Orégano)..........................................92

5.4 Piper Nigrum - (Pimenta-do-reino) ..................................... 99

5.5 Amostras estocadas por 2 meses ....................................106

5.6 Amostras controle e irradiadas das embalagens.................109

6. CONCLUSÕES.....................................................................111

7. REFERÊNCIAS BIBLIOGRÁFICAS.....................................113 


\section{LISTA DE TABELAS}

\section{Página}

TABELA 1 - Diretrizes de doses para várias aplicações da irradiação de alimentos. 26

TABELA 2 - Principais características das fontes emissoras de ${ }^{60} \mathrm{Co}$ $\mathrm{e}^{137} \mathrm{Cs}$ 31

TABELA 3 - Cronologia da irradiação de alimentos. 34

TABELA 4 - Exportações brasileiras de algumas especiarias de 1997 a 2007 61

TABELA 5 - Organização das amostras. 64

TABELA 6 - Taxas de dose da irradiação nos períodos utilizados. 66

TABELA / - Compostos majoritários presentes nas amostras controle (OkGy) de canela.

TABELA 8 - Quantificação dos compostos voláteis das amostras controle (0kGy), das amostras de dose intermediária de 10kGy e das amostras de dose final de $25 \mathrm{kGy}$

TABELA 9 - Compostos presentes nas amostras controle de noz-moscada (não-irradiada)

TABELA 10 - Quantificação dos compostos voláteis das amostras controle (0kGy), das amostras de dose intermediária de 10kGy e das amostras de dose final de 25kGy. 90

TABELA 11 - Compostos presentes na amostra controle de orégano (não-irradiada) 
TABELA 12. Quantificação dos compostos voláteis das amostras controle (0kGy), das amostras de dose intermediária de 10kGy e das amostras de dose final de 25kGy 98 TABELA 13. Compostos presentes nas amostras controle de pimenta-do-reino (não-irradiada). 99 TABELA 14. . Quantificação dos compostos voláteis das amostras controle (0kGy), das amostras de dose intermediária de 10kGy e das amostras de dose final de 25kGy 105 


\section{LISTA DE FIGURAS}

Página

FIGURA 1 - Radura: símbolo utilizado em produtos irradiados 45

FIGURA 2 - Atitude do consumidor frente à informação sobre produtos irradiados. 46

FIGURA 3 - Caneleira e canela. 49

FIGURA 4 - Noz-moscada. 51

FIGURA 5 - Orégano. 52

FIGURA 6 - Pimenta-do-reino 55

FIGURA 7 - Quilos de canela prontos para exportação. 58

FIGURA 8 - Embalagens plásticas das especiarias. 65

FIGURA 9 - Amostras prontas para serem irradiadas .67

FIGURA 10 - Aquecimento da amostras utilizando o forno do CG/MS. .68

FIGURA 11 - Exposição da fibra aos voláteis emitidos após aquecimento da amostras. 68

FIGURA 12 - Perfuração das vedação de borracha na análise das embalagens 69

FIGURA 13 - Perfis cromatográficos totais da análise das amostras de canela irradiada com a dose de 5 kGy sobreposta à uma amostra controle (0kGy) de canela.....

FIGURA 14 - Perfis cromatográficos parciais da análise das amostras de canela irradiada com a dose de 5 kGy sobreposta à uma amostra controle (0kGy) de canela. 
Página

FIGURA 15 - Perfis cromatográficos totais da análise das amostras de canela irradiada com a dose de $10 \mathrm{kGy}$ sobreposta à uma amostra controle (0kGy) de canela. .76

FIGURA 16 - Perfis cromatográficos parciais da análise das amostras de canela irradiada com a dose de $10 \mathrm{kGy}$ sobreposta à uma amostra controle (0kGy) de canela. 76

FIGURA 17 - Perfis cromatográficos totais da análise das amostras de canela irradiada com a dose de $15 \mathrm{kGy}$ sobreposta à uma amostra controle (0kGy) de canela. .77 FIGURA 18 - Perfis cromatográficos parciais da análise das amostras de canela irradiada com a dose de $15 \mathrm{kGy}$ sobreposta à uma amostra controle (0kGy) de canela. 78 FIGURA 19 - Perfis cromatográficos totais da análise das amostras de canela irradiada com a dose de $20 \mathrm{kGy}$ sobreposta à uma amostra controle (0kGy) de canela. 79 FIGURA 20 - Perfis cromatográficos parciais da análise das amostras de canela irradiada com a dose de $20 \mathrm{kGy}$ sobreposta à uma amostra controle (0kGy) de canela. 79

FIGURA 21 - Perfis cromatográficos totais da análise das amostras de canela irradiada com a dose de 25 kGy sobreposta à uma amostra controle (0kGy) de canela 80 FIGURA 22 - Perfis cromatográficos parciais da análise das amostras de canela irradiada com a dose de 25 kGy sobreposta à uma amostra controle (0kGy) de canela. 
Página

FIGURA 23 - Análise de Variáveis Canônicas da canela.

FIGURA 24 - Perfis cromatográficos totais da análise das amostras de noz-moscada irradiada com a dose de 5kGy sobreposta à uma amostra controle (0kGy) de noz-moscada. 84

FIGURA 25 - Perfis cromatográficos parciais da análise das amostras de noz-moscada irradiada com a dose de 5kGy sobreposta à uma amostra controle (0kGy) de noz-moscada. .85

FIGURA 26 - Perfis cromatográficos totais da análise das amostras de noz-moscada irradiada com a dose de 10kGy sobreposta à uma amostra controle (0kGy) de noz-moscada. .86

FIGURA 27 - Perfis cromatográficos parciais da análise das amostras de noz-moscada irradiada com a dose de 10kGy sobreposta à uma amostra controle (0kGy) de noz-moscada. .86

FIGURA 28 - Perfis cromatográficos totais da análise das amostras de noz-moscada irradiada com a dose de 15kGy sobreposta à uma amostra controle (0kGy) de noz-moscada.

FIGURA 29 - Perfis cromatográficos parciais da análise das amostras de noz-moscada irradiada com a dose de 15kGy sobreposta à uma amostra controle (0kGy) de noz-moscada.

FIGURA 30 - Perfis cromatográficos totais da análise das amostras de noz-moscada irradiada com a dose de 20kGy sobreposta à uma amostra controle (0kGy) de noz-moscada. .88

FIGURA 31 - Perfis cromatográficos parciais da análise das amostras de noz-moscada irradiada com a dose de 20kGy sobreposta à uma amostra controle (0kGy) de noz-moscada. 
Página

FIGURA 32 - Perfis cromatográficos totais da análise das amostras de noz-moscada irradiada com a dose de 25kGy sobreposta à uma amostra controle (0kGy) de noz-moscada. .89

FIGURA 33 - Perfis cromatográficos parciais da análise das amostras de noz-moscada irradiada com a dose de 25kGy sobreposta à uma amostra controle (0kGy) de noz-moscada. .89

FIGURA 34 - Análise de Variáveis Canônicas de Noz-moscada.

FIGURA 35 - Perfis cromatográficos totais da análise das amostras de orégano irradiada com a dose de 5kGy sobreposta à uma amostra controle (0kGy) de orégano. .93

FIGURA 36 - Perfis cromatográficos parciais da análise das amostras de orégano irradiada com a dose de 5kGy sobreposta à uma amostra controle (0kGy) de orégano. .93

FIGURA 37 - Perfis cromatográficos totais da análise das amostras de orégano irradiada com a dose de 10kGy sobreposta à uma amostra controle (0kGy) de orégano. .94

FIGURA 38 - Perfis cromatográficos parciais da análise das amostras de orégano irradiada com a dose de 10kGy sobreposta à uma amostra controle (0kGy) de orégano. .94

FIGURA 39 - Perfis cromatográficos totais da análise das amostras de orégano irradiada com a dose de 15kGy sobreposta à uma amostra controle (0kGy) de orégano. 
Página

FIGURA 40 - Perfis cromatográficos parciais da análise das amostras de orégano irradiada com a dose de 15kGy sobreposta à uma amostra controle (0kGy) de orégano. 95

FIGURA 41 - Perfis cromatográficos totais da análise das amostras de orégano irradiada com a dose de 20kGy sobreposta à uma amostra controle (0kGy) de orégano. .96

FIGURA 42 - Perfis cromatográficos parciais da análise das amostras de orégano irradiada com a dose de 20kGy sobreposta à uma amostra controle (0kGy) de orégano. .96 FIGURA 43 - Perfis cromatográficos totais da análise das amostras de orégano irradiada com a dose de 25kGy sobreposta à uma amostra controle (0kGy) de orégano. .97

FIGURA 44 - Perfis cromatográficos parciais da análise das amostras de orégano irradiada com a dose de $25 \mathrm{kGy}$ sobreposta à uma amostra controle (0kGy) de orégano. .97

FIGURA 45 - Análise de Variáveis Canônicas do Orégano. .98

FIGURA 46 - Perfis cromatográficos totais da análise da amostra de pimenta-do-reino irradiada com 5 kGy sobreposta à amostra controle (0kGy) de pimenta-do-reino. 100 FIGURA 47 - Perfis cromatográficos parciais da análise da amostra de pimenta-do-reino irradiada com 5 kGy sobreposta à amostra controle (0kGy) de pimenta-do-reino. 100

FIGURA 48 - Perfis cromatográficos totais da análise da amostra de pimenta-do-reino irradiada com 10 kGy sobreposta à amostra controle (0kGy) de pimenta-do-reino. 101 
Página

FIGURA 49 - Perfis cromatográficos parciais da análise da amostra de pimenta-do-reino irradiada com 10 kGy sobreposta à amostra controle (0kGy) de pimenta-do-reino. 101

FIGURA 50 - Perfis cromatográficos totais da análise da amostra de pimenta-do-reino irradiada com 15 kGy sobreposta à amostra controle (0kGy) de pimenta-do-reino. 102

FIGURA 51 - Perfis cromatográficos parciais da análise da amostra de pimenta-do-reino irradiada com 15 kGy sobreposta à amostra controle (0kGy) de pimenta-do-reino. 102

FIGURA 52 - Perfis cromatográficos totais da análise da amostra de pimenta-do-reino irradiada com 20 kGy sobreposta à amostra controle (0kGy) de pimenta-do-reino. 103

FIGURA 53 - Perfis cromatográficos parciais da análise da amostra de pimenta-do-reino irradiada com 20 kGy sobreposta à amostra controle (0kGy) de pimenta-do-reino. 103

FIGURA 54 - Perfis cromatográficos totais da análise da amostra de pimenta-do-reino irradiada com 25 kGy sobreposta à amostra controle (0kGy) de pimenta-do-reino. .104

FIGURA 55 - Perfis cromatográficos parciais da análise da amostra de pimenta-do-reino irradiada com 25 kGy sobreposta à amostra controle (0kGy) de pimenta-do-reino. 104

FIGURA 56. Análise de Variáveis Canônicas de

Pimenta-do-reino 105

FIGURA 57 - Picos cromatográficos parciais das amostras de pimeta-do-reino irradiadas com 0 e 5kGy após estocagem. 107

FIGURA 58 - Picos cromatográficos parciais das amostras de pimeta-do-reino irradiadas com 10 e 15kGy após estocagem 
Página

FIGURA 59 - Picos cromatográficos parciais das amostras

de pimeta-do-reino irradiadas com 20 e 25kGy após estocagem.......... 109

FIGURA 60 - Análise de Variáveis Canônicas

(Método de Correlação) das amostras de embalagem..........................110

FIGURA 61 - Análise de Covariância das amostras

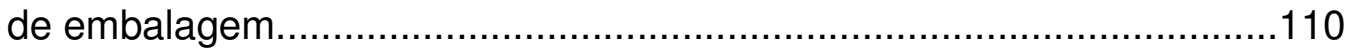




\section{INTRODUÇÃO}

Em 1895, o físico alemão Wilhelm G. Röntgen, acidentalmente descobriu os raios $\mathrm{X}$, o que levou ao estudo dessa radiação por diversos pesquisadores, dentre os quais Antoine $\mathrm{H}$. Becquerel, que três anos depois descobriria a radioatividade. Essa descoberta tornou-se a pedra fundamental de sucessivas pesquisas e avanços importantes, traçando a história da Química Nuclear e de suas aplicações. Em 1900, o físico neozelandês Ernst Rutherford e o casal franco-polonês Pierre e Marie Curie identificaram as partículas $\alpha$ (alfa) e $\beta$ (beta). Paralelamente, o francês Paul Villard descobria a radiação y (gama) (Tébeka \& Hallwas, 2007).

Rutherford, em 1903, formulou o conhecido modelo atômico, hoje conhecido como "planetário", prevendo a presença de um núcleo central em todos os átomos. Segundo ele, este núcleo seria capaz de emitir partículas a e b, assim como, radiação gama quando instável, sugerindo então que alguns elementos eram naturalmente radioativos (Tébeka \& Hallwas, 2007). Posteriormente, em 1934, o casal Irène Curie e Frédéric Joliot descobriu a radioatividade artificial, pelo do bombardeamento com partículas a de uma folha de alumínio, levando à criação do ${ }^{30} \mathrm{P}$, um radioisótopo inexistente na natureza. A partir dessa descoberta, as radiações e emissões nucleares, tanto naturais quanto artificiais, passaram a ser estudadas com mais afinco do ponto de vista tecnológico, e mais especificamente para aplicações industriais.

Do ponto de vista histórico, a Química Nuclear deixou mais marcas negativas do que positivas de sua aplicação. Entretanto, os principais investimentos tecnológicos atuais nessa área estão direcionados para a aplicação pacífica das radiações nucleares, tal como a irradiação de alimentos (Farkas, 2006). 
A aplicação da radiação ionizante, com o propósito de preservar e desinfestar alimentos e ervas medicinais, surge como uma prática efetiva, impedindo a divisão de células vivas, tais como bactérias e células de organismos superiores ao alterar suas estruturas moleculares e produzir reações bioquímicas nos processos fisiológicos(Calucci et al., 2003), consequentemente a redução de organismos patogênicos dos alimentos. É utilizada também para aumentar a vida de prateleira de determinados produtos devido à redução da contaminação por microorganismos espoliadores (Farkas, 2006).

Nos últimos anos, tem se verificado entre a população uma tendência crescente, pelo consumo de alimentos minimamente processados ou livres de aditivos ou produtos químicos, como os chamados orgânicos. Especiarias, grãos, carnes, frutas e tubérculos são tratados pela irradiação em cerca de quarenta países atualmente (MDS NORDION, 2006). De acordo com Horváthová e seus colaboradores em 2007, dentre a grande variedade de produtos alimentícios, as especiarias são frequentemente as mais irradiadas.

A presença de patógenos microbiológicos nos alimentos é um sério problema global, mesmo em países altamente desenvolvidos, como os Estados Unidos. Os alimentos contaminados com patógenos humanos têm causado impactos na saúde e na economia. Segundo dados do Centro de Controle de Doenças (CDC, 2004) a cada ano ocorrem 76 milhões de infecções, 325 mil hospitalizações, e aproximadamente 5 mil mortes causadas por patógenos alimentares (Smith, 2004), sendo que, uma das causas dessas mortes por doenças alimentares são infecções por bactérias como, por exemplo, Salmonella e Campylobacter (Rela, 2000; ICGFI, 1999).

Os especialistas do CDC estimam que a irradiação de metade de todos os alimentos com base de carne bovina, suína e de aves, e até mesmo os processados poderiam reduzir em 1 milhão os casos de infecções alimentares, 
prevenir 6 mil sérias doenças e 350 mortes por ano (Tauxe, 2001), impactando financeiramente na saúde pública.

O interesse pela irradiação como tecnologia de tratamento de alimentos também tem forte justificativa econômica devido às grandes perdas decorrentes da infestação por insetos, contaminação e deterioração por microrganismos, além da germinação prematura de tubérculos ou da maturação, no caso das frutas. Estimativas da FAO (Organização das Nações Unidas para a Agricultura e Desenvolvimento) indicam que cerca de $25 \%$ da produção mundial de alimentos é perdida devido à contaminação por bactérias e ação de insetos e roedores. Porém, algumas mudanças químicas são induzidas nos alimentos como resultado da irradiação. De fato, qualquer tratamento pelo qual um alimento seja submetido, aquecimento ou radiação ionizante, há alteração de algumas propriedades químicas dos alimentos. Portanto, é fundamental avaliar os efeitos químicos e físicos provocados pela interação da radiação ionizante com o produto irradiado (Tauxe, 2001).

O conhecimento científico dos compostos químicos responsáveis pelo odor e sabor característico das especiarias, denominados compostos voláteis, justificase pela importância que estas desempenham na qualidade dos alimentos.

Consideráveis esforços têm sido realizados para determinar os efeitos da irradiação sobre os vários componentes do alimento (Nawar, 1996).

Com o intuito de não somente preservar 0 alimento combatendo microorganismos patogênicos e aumentar o tempo de prateleira, mas também a preservação da integridade sensorial do alimento, já que este é um dos principais fatores exigidos pelo consumidor, torna-se necessário a análise de compostos voláteis formados pela irradiação de ervas alimentícias e medicinais e, as possíveis mudanças sensoriais dessas ervas após o tratamento com radiação e estocagem, caracterizando as diferentes doses utilizadas e seus 
efeitos sobre o valor sensorial das especiarias, visando a melhor aplicação desta tecnologia. 


\section{OBJETIVOS}

\subsection{Objetivo Geral}

O presente trabalho tem por objetivo analisar os compostos voláteis liberados pela canela (Laurus Cinnamomum), pimenta-do-reino (Piper Nigrum), orégano (Origanum Vulgare), noz-moscada (Myristica Fragans).

\subsection{Objetivos Específicos}

$\checkmark$ Caracterizar $o$ perfil de compostos voláteis presentes em especiarias.

$\checkmark$ Determinar o perfil de compostos voláteis após o processamento por radiação de ${ }^{60} \mathrm{Co}$.

$\checkmark$ Avaliar a influência do período de dois meses de estocagem após a irradiação.

Avaliar a possível interferência dos compostos voláteis emitidos pela embalagem durante a irradiação das amostras, podendo contribuir para diferenças sensoriais das especiarias. 


\section{REVISÃO DA LITERATURA}

\subsection{Irradiação de Alimentos}

A irradiação de alimentos é um tratamento físico que consiste na exposição dos alimentos, já embalados ou a granel, a uma fonte de radiação ionizante, durante o tempo necessário para se obterem as alterações desejáveis (IAEA, 1992; Diehl, 2002).

É um método de pasteurização a frio (sem produção de aquecimento) utilizado para controlar doenças de origem alimentar causadas por microrganismos patogênicos, parasitas, especialmente em alimentos que são consumidos crus ou parcialmente processados (Loaharanu, 1997), além de apresentar característica única de poder ser aplicada em alimentos congelados (Farkas, 1998). A irradiação também possui a vantagem de consumir menor quantidade de energia no processo de tratamento dos alimentos se comparado a métodos convencionais (Tébéka e Hallwass, 2007).

O processamento por radiação tem sido utilizado industrialmente com segurança por mais de 40 anos. Desde 1964, principalmente, a Organização Mundial de Saúde (OMS) acompanha os resultados de estudos com alimentos irradiados, em conjunto com a Organização das Nações Unidas para Agricultura e Alimentação (FAO) e a Agência Internacional de Energia Atômica (AIEA), por meio de reuniões com especialistas de diversos países do mundo. Em setembro de 1997, a OMS aprovou e recomendou a irradiação de alimentos, em doses que não comprometam suas características organolépticas, sem a necessidade de testes toxicológicos. A partir disto, a irradiação de determinados alimentos e ingredientes para alimentos foi aprovada pelas autoridades de saúde em aproximadamente 60 países (Delincee, 2005). 
A radiação mais utilizada no processo de conservação de alimentos é a do tipo y (gama), mas também são utilizados em menor escala raios $X$ e feixes de elétrons. A incidência da radiação sobre o produto alvo induz a formação de íons dos átomos do material, incluindo-se os microorganismos presentes, levando à alteração biológica dos componentes potencialmente capazes de deteriorar o produto irradiado. Com isso, torna-se possível o armazenamento dos alimentos por um prazo mais extenso, comparado ao armazenamento sem irradiação prévia, dispensando o uso de conservantes químicos muitas vezes nocivos à saúde (Delincee 2005).

A irradiação apresenta-se, portanto, como um método simples e seguro para a preservação e armazenamento de alimentos em longo prazo, sendo uma alternativa mais atrativa e saudável na indústria alimentícia quando comparada aos tratamentos químicos, proibidos atualmente, porque muitos deixam resíduos tóxicos (Calucci et al., 2003). Além disso, a irradiação de alimentos atende medidas de preservação ambiental, diminuindo gastos energéticos e riscos sanitários.

Segura, econômica e eficiente, o tratamento de alimentos por meio de radiação ionizante, é uma técnica cuja aplicação industrial vem se desenvolvendo intensamente nos últimos 15 anos (Diehl, 2002).

De acordo com Crawford e Ruff em 1996, a irradiação de alimentos tem como finalidade:

- inibir o brotamento de raízes

- retardar o amadurecimento de frutas e vegetais

- reduzir microorganismos patogênicos

- aumentar a vida de prateleira do alimento

- $\quad$ suprir o abastecimento nos períodos de entressafra 
As aplicações descritas por Crawford e Ruff foram encaixadas, na prática, em três categorias de doses pelo Grupo Consultivo Internacional sobre Irradiação de Alimentos (ICGFI). São elas:

- Irradiação de dose baixa - até 1kGy (inibição de brotamento; atraso na maturação; desinfestação de insetos; inativação de parasitas).

- Irradiação de dose média - 1 a 10kGy (redução do número de microrganismos de decomposição; redução do número ou eliminação de patógenos não formadores de esporos; isto é, microrganismos causadores de doenças).

- Irradiação de dose alta - acima de 10kGy (redução do número de microrganismos ao ponto da esterilidade) (ICGFI, 1999).

Na TABELA 1, Farkas (2006), apresenta algumas diretrizes para diferentes aplicações da irradiação de alimentos.

TABELA 1- Diretrizes de doses para várias aplicações da irradiação de alimentos.

\begin{tabular}{lc}
\hline Efeitos Preventivos e Tipos de Aplicação & Dose (kGy) \\
\hline Desinfestação de insetos (esterilização) & $0,2-0,8$ \\
$\begin{array}{l}\text { Prevenção da reprodução de parasitas alimentares } \\
\text { Retardo do amadurecimento e da senescência de algumas }\end{array}$ & $0,1-3,0$ \\
frutas e legumes & \\
$\begin{array}{l}\text { Eliminação de microorganismos patogênicos não-esporulados } \\
\text { (exceto vírus) em alimentos congelados e frescos. }\end{array}$ & $1,0-7,0$ \\
$\begin{array}{l}\text { Redução ou eliminação da população microbiana em } \\
\text { ingredientes alimentares secos }\end{array}$ & $3,0-10$
\end{tabular}

Fonte - Farkas, 2006. 
Porém, assim como outros métodos, a irradiação não pode inverter 0 processo de decomposição e fazer com que o alimento deteriorado se torne próprio para o consumo (Del Mastro, 1999).

A aplicação da radiação ionizante no tratamento dos alimentos é baseada principalmente no princípio de que a mesma causa uma ruptura muito eficaz nas moléculas do DNA, no núcleo das células (Diehl 1995), tornando-as inativas. Portanto, os gametas de microorganismos e de insetos, meristemas vegetais são impedidos de se multiplicarem, conseqüentemente, resulta em vários efeitos conservantes em função da dose de radiação absorvida (TABELA 1).

De acordo com um estudo publicado por Arena (1971), a radiação ionizante causa a perda de um elétron na molécula da água produzindo $\mathrm{H}_{2} \mathrm{O}+$. Este produto imediatamente reage com outras moléculas da água para produzir uma série de compostos, incluindo o hidrogênio, radicais hidroxila $(\mathrm{OH} \bullet)$, hidrogênio molecular, oxigênio e peróxido de hidrogênio $\left(\mathrm{H}_{2} \mathrm{O}_{2}\right)$. Os radicais hidroxila são muito reativos e conhecidos por modificarem bases nitrogenadas.

Embora os sistemas biológicos tenham capacidade para reparar tanto quebras simples quanto duplas do DNA, os danos ocasionados a partir das radiações ionizantes são aleatórios e extensos (Razskazovskiy et al., 2003). Uma importante razão para a sensibilidade relativamente alta do DNA para os efeitos das radiações ionizantes, é o fato de que as moléculas de DNA são muito maiores do que outras estruturas moleculares no interior da célula.

Os efeitos da radiação não podem ser descritos de maneira geral para todos os organismos, uma vez que, esses efeitos estão relacionados com a natureza do organismo e, principalmente, com a sua complexidade. A irradiação ionizante pode causar danos aos microorganismos de modo direto ou indireto. A ação direta ocorre quando a radiação atinge diretamente o DNA microbiano impedindo sua reprodução e a ação indireta ocorre pela ionização de moléculas adjacentes ao DNA gerando radicais livres e estes radicais por sua vez, atacam 
o material genético. A água é a principal molécula na maioria dos alimentos e microorganismos, e freqüentemente a molécula adjacente que mais atua na mortalidade destes micróbios (Grecz et al., 1983).

A correlação da sensitividade à irradiação é, de maneira geral, inversamente proporcional ao tamanho do organismo. A relativa sensibilidade de diferentes microorganismos a radiação é dependente do seu valor $D_{10}$ (dose suficiente para reduzir a população microbiana em 1 log, ou seja, 90\%). Assim sendo, cada microorganismo requer uma dose específica para sua eliminação (Smith, 2004). Leveduras e fungos têm uma suscetibilidade à radiação comparada a de algumas bactérias não formadoras de esporos. As doses letais para leveduras estão, aproximadamente, na faixa de 4,65 a 20kGy e para os bolores entre 2,5 a 6,0kGy (Smith, 2004).

A quantidade de radiação necessária para controlar microrganismos nos alimentos, entretanto, varia também em função da resistência da espécie em particular e o número de organismos presentes. Além das habilidades inerentes dos microrganismos, vários fatores ambientais, tais como a composição do meio, teor de umidade, temperatura durante a irradiação, presença ou ausência de oxigênio, entre outros, influenciam significativamente na capacidade de resistência desses microorganismos a radiações, em particular nas células vegetativas (Razskazovskiy et al., 2003).

O impacto da irradiação sobre os nutrientes tem sido motivo de muitas pesquisas na área de alimentos, observando-se que as alterações são as mesmas que ocorrem em outros processos empregados na conservação de alimentos, principalmente no que se refere à oxidação de lipídios e formação de radicais livres.

A influência na qualidade nutritiva dos alimentos não é maior do que a dos outros métodos convencionais utilizados para o tratamento e conservação como, 
por exemplo, o método de aquecimento (Henry, Chapman, 2002), não afetando significamente o alimento (Lima et al., 2001).

Os macronutrientes são relativamente estáveis, quando os alimentos são expostos à dose máxima de irradiação de 10kGy (1Mrad ou 1000.000 rad). Os micronutrientes, em especial as vitaminas, podem sofrer redução em pequenas proporções pelo emprego da irradiação. A sensibilidade das vitaminas ao processo é variada, dependendo das condições nas quais se irradiam os alimentos. As vitaminas C e B1 são as mais sensíveis no grupo das hidrossolúveis e, as vitaminas $\mathrm{E}$ e $\mathrm{A}$ as mais sensíveis no grupo das lipossolúveis (Lima et al., 2001).

A tecnologia da irradiação de alimentos é tão segura que, contanto que as qualidades sensoriais do alimento sejam mantidas e os microorganismos nocivos sejam destruídos, a quantidade real de radiação ionizante aplicada é considerada secundária (ICGF, 1999), ou seja, a dose real empregada deve ser um ponto de equilíbrio entre aquilo que é necessário e aquilo que pode ser tolerado pelos produtos sem alterações questionáveis como, por exemplo, alterações no sabor e na textura (Razskazovskiy et al., 2003).

O interesse no processo é crescente, devido às grandes perdas de alimentos por infestação, contaminação e deterioração; aumento crescente das preocupações sobre doenças originadas nos alimentos; regulamentos restritivos ou total proibição do uso de fumigantes químicos (ICGF, 1999).

\subsubsection{Fontes de Irradiação de alimentos}

De acordo com o Codex General Standard for Irradiated Foods do Codex Alimentarius (1984), para irradiação de alimentos só são permitidos os raios gama, provenientes dos radionuclídeos ${ }^{60} \mathrm{Co}$ e ${ }^{137} \mathrm{Cs}$; máquinas de raios $\mathrm{X}$ 
possuindo uma energia máxima de cinco milhões de eletronvolt (MeV); ou aceleradores de elétrons com um máximo de $10 \mathrm{MeV}$.

O radionuclídeo mais utilizado na irradiação de alimentos por raios gama é o ${ }^{60} \mathrm{Co}$, produzido pelo bombardeamento com nêutrons, em um reator nuclear, do metal ${ }^{59} \mathrm{Co}$. Este então, duplamente encapsulado em "lápis" de aço inoxidável para impedir qualquer fuga durante seu uso em um irradiador (Codex Alimentarius, 1984).

Segundo Esteves (1997), os principais critérios de seleção dos radionuclídeos utilizados como fonte de radiação gama são:

- características físicas;

- características da radiação emitida;

- Disponibilidade;

- Segurança;

- preço.

Tais características são apresentadas resumidamente na TABELA 2. 
TABELA 2 - Principais características das fontes emissoras de ${ }^{60} \mathrm{Co}$ e ${ }^{137} \mathrm{Cs}$.

\begin{tabular}{|c|c|c|}
\hline Características & ${ }^{60} \mathrm{Co}$ & ${ }^{137} \mathrm{Cs}$ \\
\hline Forma da Fonte & Metal & Cloreto de Césio \\
\hline Origem & Cobalto Natural & $\begin{array}{l}\text { Produto da fissão nuclear do } \\
\text { urânio }\end{array}$ \\
\hline Meia-vida & 5,3 anos & 30 anos \\
\hline Decaimento & $12,39 \%$ ao ano & $2,28 \%$ ao ano \\
\hline Produção & $\begin{array}{l}\text { Por ativação com } \\
\text { nêutrons do }{ }^{60} \mathrm{Co} \text { num } \\
\text { reator nuclear }\end{array}$ & $\begin{array}{c}\text { Separação por métodos químicos } \\
\text { dos outros subprodutos do } \\
\text { combustível nuclear }\end{array}$ \\
\hline $\begin{array}{l}\text { Energia dos } \\
\text { Fótons }\end{array}$ & 1,17MeV e $1,33 \mathrm{MeV}$ & $0,66 \mathrm{MeV}$ \\
\hline Produto Final & ${ }_{28}^{60} \mathrm{Ni}$ & ${ }_{56}^{137} \mathrm{Ba}$ \\
\hline $\begin{array}{c}\text { Solublidade em } \\
\text { água }\end{array}$ & Nula & Rápida \\
\hline $\begin{array}{l}\text { Atividade } \\
\text { Específica }\end{array}$ & Até $400 \mathrm{Ci} / \mathrm{g}$ & $25 \mathrm{Ci} / \mathrm{g}$ \\
\hline
\end{tabular}

Fonte - Oliveira, 2000

$\mathrm{O}{ }^{60}$ Co possui uma meia-vida de 5,3 anos, os raios gama produzidos são altamente penetrantes e são usados para tratar embalagens com alimento fresco ou congelado. $\mathrm{O}{ }^{137} \mathrm{Cs}$ possui uma meia-vida de 30 anos, entretanto, quase não é utilizado (Oliveira, 2000).

É importante salientar que tanto a radiação gama, como a dos feixes de elétrons dos aceleradores, não têm energia suficiente para provocar qualquer reação nuclear na matéria e, portanto, não deixam nenhum resíduo radioativo no material após a irradiação (Diehl, 1995). 


\subsection{Histórico da Irradiação de Alimentos}

A investigação sobre a irradiação de alimentos começou logo em 1905 e tem demonstrado através de muitos anos de estudos científicos ser um processo saudável. No início de 1920, um cientista francês descobriu que a irradiação poderia ser utilizada para preservar alimentos, mas a tecnologia não foi estudada extensivamente nos Estados Unidos até a Segunda Guerra Mundial. As pesquisas em irradiação de alimentos resultaram de um programa intitulado "Atoms for Peace" (Átomos para Paz) no início de 1950, estabelecido pelo presidente americano Eisenhower (Boisseau, 1994).

A primeira aprovação para o uso da irradiação em produtos alimentícios dada pela Food and Drug Administration (FDA) foi em 1963 para irradiar trigo e farinha de trigo com a finalidade de desinfestação de insetos (Sanz, 2008).

Em 1983, foi concedida a aprovação da irradiação para matar insetos e para o controle de microorganismos numa lista específica de ervas, especiarias e condimentos vegetais (Boisseau, 1994).

A aprovação da irradiação para o tratamento de carne de porco para prevenção de Trichinosis foi em 1985. No mesmo ano, houve a aprovação para o controle de insetos e microorganismos em preparados de enzimas secas para processos de fermentação. No ano de 1986, a irradiação foi aprovada para o controle de insetos e para inibir amadurecimento acelerado em alimentos como frutas, vegetais e grãos. Em maio de 1990, houve aprovação para controle bacteriano em embalados frescos e aves congeladas (Boisseau, 1994).

O FDA, em dezembro de 1997, aprovou a irradiação para carnes vermelhas congeladas e frescas tais como carne bovina e de cordeiros nos Estados Unidos. Esta aprovação teve o objetivo de controlar microorganismos, como $E$. coli 0157:H7 e outros patógenos alimentares. A aprovação foi baseada numa 
revisão científica a nível mundial feita pelo FDA, onde foram consideradas numerosas pesquisas sobre os efeitos da irradiação numa variedade de produtos alimentícios. Os estudos investigaram os efeitos químicos da radiação, impactos no conteúdo nutricional de produtos irradiados, problemas toxicológicos, e os efeitos nos microorganismos em produtos irradiados e não irradiados (Boisseau, 1994).

No Brasil, as primeiras pesquisas com irradiação de alimentos foram feitas na década de 50, pelo Centro de Energia Nuclear na Agricultura (CENA), em Piracicaba (SP). Mesmo com a permissão em 1985 do uso da irradiação para conservação de alimentos, os estudos se restringiram quase que exclusivamente às instituições de pesquisas, uma vez que o País contava com um número restrito de especialistas (Sanz, 2008).

De acordo com Sanz (2008), muitos outros países já adotaram este processo para pasteurizar ou preservar alimentos. Mundialmente, mais de 30 países aprovaram alguma forma de irradiação.

Na TABELA 3, é possível observar os principais eventos cronológicos, no progresso e na utilização da irradiação. 
TABELA 3 - Cronologia da irradiação de alimentos

\begin{tabular}{|c|c|}
\hline Ano & Evento \\
\hline 1905 & $\begin{array}{l}\text { Cientistas recebem patentes para um processo de preservação } \\
\text { de alimentos que utiliza radiação ionizante para matar bactérias } \\
\text { em alimentos. }\end{array}$ \\
\hline 1921 & $\begin{array}{c}\text { É concedida aos Estados Unidos uma patente para o processo } \\
\text { que mataria Trichinella spiral em carnes, utilizando tecnologia de } \\
\text { raios-X. }\end{array}$ \\
\hline 1953-1980 & $\begin{array}{c}\text { O governo dos Estados Unidos cria o Programa Nacional de } \\
\text { Irradiação de Alimentos. Dentro desse programa, o Exército dos } \\
\text { Estados Unidos e a Comissão de Energia Atômica patrocinam } \\
\text { numerosos projetos de investigação sobre a irradiação de } \\
\text { alimentos. }\end{array}$ \\
\hline 1958 & $\begin{array}{c}\text { A lei Federal sobre Alimentos, Medicamentos e Cosméticos } \\
\text { (Federal Food, Drug and Cosmetic Act -FFDCA) é alterada e } \\
\text { define as fontes de radiação destinadas a utilização no } \\
\text { processamento de alimentos como um novo aditivo alimentar. Lei } \\
\text { administrada pelo FDA. }\end{array}$ \\
\hline 1963 & $\begin{array}{l}\text { O FDA aprova a irradiação para controlar insetos em trigo e } \\
\text { farinha. }\end{array}$ \\
\hline 1964 & $\begin{array}{l}\text { O FDA aprova irradiação para inibir a germinação em batatas } \\
\text { brancas. }\end{array}$ \\
\hline 1964-1968 & $\begin{array}{c}\text { O Exército dos Estados Unidos e a Comissão de Energia Atômica } \\
\text { fazem uma petição ao FDA para a aprovação da irradiação de } \\
\text { diversos materiais para embalagem. }\end{array}$ \\
\hline 1966 & $\begin{array}{c}\text { O Exército dos Estados Unidos e o USDA (Departamento de } \\
\text { Agricultura dos Estados Unidos) fazem uma petição ao FDA para } \\
\text { a aprovação da irradiação de presunto. }\end{array}$ \\
\hline 1971 & $\begin{array}{l}\text { FDA aprova a irradiação de diversos materiais para embalagens } \\
\text { com base na petição de 1964-1968 feita pelo Exército dos } \\
\text { Estados Unidos e pela Comissão de Energia Atômica. }\end{array}$ \\
\hline 1976 & $\begin{array}{l}\text { O Exército dos Estados Unidos contrata companhias comerciais } \\
\text { para o estudo da salubridade dos irradiados: presunto, carne de } \\
\text { porco e carne de frango. }\end{array}$ \\
\hline 1980 & $\begin{array}{l}\text { USDA associa-se ao Exército dos Estados Unidos no programa } \\
\text { de irradiação de alimentos }\end{array}$ \\
\hline 1985 & $\begin{array}{l}\text { FDA aprova irradiação em doses específicas para controlar } \\
\text { Trichinella spiral em carne de porco. }\end{array}$ \\
\hline
\end{tabular}


1986 A Lei Federal de Inspeção de Alimentos dos Estados Unidos é alterada para permitir a radiação gama para controlar Trichinella spiral em carne de porco fresca ou previamente congelada. A lei é administrada pelo USDA.

1990 FDA aprova irradiação de poultry para o controle de Salmonela e outras bactérias de origem alimentar

USDA aprova irradiação de poultry para o controle de Salmonela e outras bactérias de origem alimentar

Regulamentos do FDA foram alterados para permitir as radiações ionizantes no tratamento de refrigerados ou congelados não

1997 cozidos de carnes, produtos derivados, e de certos produtos alimentares para controlar os agentes patogênicos de origem alimentar, e para aumentar a vida de prateleira.

Regulamentos do USDA foram alterados para permitir as radiações ionizantes no tratamento de refrigerados ou congelados não cozidos de carnes, produtos derivados, e de certos produtos alimentares para controlar os agentes

2000 patogênicos de origem alimentar, e para aumentar a vida de prateleira.

Regulamentos do FDA foram alterados para permitir a irradiação de casca de ovos frescos para o controle de Salmonela.

Fonte - United States General Accounting Office - EPA/USA

\subsection{Irradiação de alimentos no mundo}

O aumento da construção de instalações de irradiação ao redor do mundo poderá ter um efeito direto sobre o comércio internacional. Pestes, como moscas de frutas, tem sido comercialmente, um obstáculo para os países que produzem frutas tropicais e legumes (Food \& Water Watch, 2006).

A irradiação pode fornecer um meio para erradicar pragas, tornando elegíveis produções exóticas com objetivo de exportação para os Estados Unidos. 
Internacionalmente, os Estados Unidos é conhecido como um influente mercado de alimentos irradiados (Food \& Water Watch, 2006).

Em 2006, os acordos comerciais para irradiação de alimentos foram assinados entre os Estados Unidos e vários países ao redor do mundo, inclusive o Brasil. Esta tendência deverá manter-se. Para efeito de comparação, segue a continuação informações sobre a história e a atual situação da irradiação de alimentos nos países mais influentes dos cinco continentes mundiais:

\section{ÀSIA}

- China

A China é um mercado de rápido crescimento para a irradiação, como toda região Ásia/Pacífico, em geral. A China é o sustentador (incentivador) da irradiação e o crescimento tem sido rápido nos últimos anos. A primeira instalação para a irradiação de alimentos foi construída em 1987. A China tinha apenas sete instalações em 2003, porém em março de 2006 esse número subiu para 78, com 50 delas para processamento de alimentos. Tanto a radiação gama quanto por acelerador de elétrons são utilizados (IMIP, 2006).

$\mathrm{Na}$ China, a irradiação é utilizada principalmente para inibir a germinação do alho. Também é utilizada para descontaminação bacteriana em produtos hortícolas desidratados, especiarias, grãos e ervas medicinais. Espera-se que a irradiação de alimentos na China seja utilizada no futuro como um tratamento para a exportação de alimentos (Food \& Water Watch, 2006).

O Ministério de Saúde Pública Chinês aprovou a irradiação em 1986, incluindo regras para a instalação, gestão pessoal, dose, etiquetagem e punição para violações (Food \& Water Watch, 2006). 
- $\quad$ Filipinas

Nas Filipinas, a indústria da manga é altamente produtiva, e o mercado de exportação poderia absorver excedentes de produção. No entanto, a maioria da produção não pode ser exportada devido à contaminação por pragas, frutos de qualidade baixa, vida útil deficiente e os custos altos de transporte (Food Standards Agency, 2006).

O Governo filipino acredita que a irradiação poderia ser um tratamento de quarentena efetivo para desinfestação de frutas para exportação (Food Standards Agency, 2006).

O governo tem pressionado o Departamento de Agricultura dos Estados Unidos (United States Department of Agriculture - USDA) por uma concessão de US \$ 10 milhões para a instalação. Em resposta, o USDA doou 9300 toneladas de trigo em 2005, onde as Filipinas poderia vender com o intuito de arrecadar dinheiro para ajudar na instalação. Porém, nenhuma outra assistência do USDA tem sido relatada desde 2005 (Food Standards Agency, 2006).

- $\quad$ Tailândia

Em fevereiro de 2006, o Serviço de Inspeção Fitossanitária e Animal do Departamento de Agricultura dos Estados Unidos (USDA's Animal and Plant Health Inspection Service - APHIS) assinou um acordo com a Tailândia permitindo a utilização da irradiação para matar os parasitas em frutos e produtos hortícolas exportados para os E.U.A (USD News Released, 2006).

A Tailândia é o primeiro país a chegar num acordo deste nível com os Estados Unidos. 
- Índia

A Índia utiliza a irradiação em muitos produtos agrícolas. A irradiação foi aprovada para as cebolas, batatas, chalotas, arroz, especiarias, mariscos secos, uvas passa, figos, tâmaras, mariscos frescos, mariscos congelados, produtos à base de carne e mangas (Food \& Water Watch, 2006).

A Índia está utilizando principalmente a irradiação gama de ${ }^{60} \mathrm{Co}$, os aceleradores de elétrons também estão sendo planejados. O Departamento de Energia Atômica esta construindo duas instalações monstruosas que utilizam ${ }^{60} \mathrm{Co}$, ambos perto de Bombaim (maior cidade da Índia e capital do estado de Maharashtra) e mais três estão em planejamento (Food \& Water Watch, 2006).

Em março de 2006, o presidente dos Estados Unidos, George W. Bush, foi para a Índia e chegou à um acordo com o Primeiro-Ministro da Índia, Manmohan Singh. Entraram em acordo para a utilização da irradiação como um tratamento pós-colheita de frutos e produtos hortícolas para o comércio. Porém, acordos complementares deverão ser feitos entre os Estados Unidos e a Índia para que haja a possibilidade de exportação de mangas irradiadas para os EUA (Food \& Water Watch, 2006).

- Irã

De acordo com o Food \& Water Wash (2006), o Irã está investigando o uso da irradiação para a redução da contaminação bacteriana em camarão.

Os pesquisadores acreditam que a irradiação pode substituir tratamentos químicos existentes. A partir de 2003, instalações para irradiação comercial de alimentos estavam localizadas em Teerão e Yazd (províncias iranianas). 
- $\quad$ Paquistão

Existem planos para a construção de duas instalações para irradiação de alimentos, nas cidades de Lahore e Karachi.

Existem planos para irradiar uma variedade de alimentos incluindo arroz, trigo, cereais, frutas, legumes e especiarias com radiação gama. A construção da instalação já foi iniciada na cidade de Lahore (Food \& Water Watch, 2006).

\section{AMÉRICA CENTRAL E AMÉRICA DO SUL}

- México

A empresa mexicana Phytosan planeja construir duas instalações para irradiação de alimentos no México. Uma delas será na cidade de Matehuala e a outra em Guadalajara, em 2008 (Phytosan S.A., 2006). Os produtos tratados seriam: goiaba, carambola, uva, tangerina e manga para exportação aos Estados Unidos. Em 25 de abril de 2006, o México e os Estados Unidos assinaram um acordo para utilizar a irradiação como um tratamento pós-colheita de frutos e produtos hortícolas para exportação.

\section{- Brasil}

Em julho de 2006, o Ministério da Agricultura realizou uma reunião para discutir uma proposta de regulamento para a utilização de irradiação para eliminar pragas sobre as exportações. A agência acredita que a tecnologia pode abrir novos mercados de exportação para frutas frescas, especialmente mangas. O Brasil exportou 115.000 toneladas de mangas, em 2005, que trouxe US \$ 76 milhões para o país (Lobo, 2006). 
Atualmente no Brasil existem apenas duas companhias responsáveis em irradiar produtos em escala industrial, a EMBRARAD (Empresa Brasileira de Radiações) e a CBE (Companhia Brasileira de Esterilização), que utilizam o ${ }^{60} \mathrm{Co}$ como fonte de energia. Localizada em Cotia, a EMBRARAD tem atualmente 50 funcionários e cerca de 400 clientes no País. Desse número, 58\% da receita é gerada na irradiação de material médico-cirúrgico, 12\% de fitoterápico e ervas e, 10\% de cosmético. Já a CBE foi fundada em 1999 e detém tecnologia 100\% nacional. Localizada em Jarinu, interior paulista, a empresa tem 40 funcionários e um parque industrial mais moderno (Rela et al., 2005).

Em 2004, o Centro de Tecnologia das Radiações (CTR) do Instituto de Pesquisas Energéticas e Nucleares (IPEN), inaugurou o terceiro irradiador comercial em funcionamento no país. O equipamento do IPEN com tecnologia $100 \%$ nacional, também utiliza como fonte $0{ }^{60} \mathrm{Co}$, entretanto possui dimensões menores sendo considerado um equipamento multipropósito de caráter semiindustrial (Rela et al., 2005).

\section{EUROPA}

A União Européia tem proibido novas aprovações sobre a irradiação devido ao questionamento de pesquisas científicas sobre a segurança de alguns produtos químicos chamados de ciclobutamonas formados nos alimentos, quando estes, são expostos à radiação (Food Standardas Agency, 2006)

Organizações "anti-irradiação" lançaram uma campanha para manter a proibição de novas aprovações e desafiam as homologações existentes para reduzir a quantidade de alimentos irradiados na Europa (Food Standards Agency, 2006). 
- França

A França permite a irradiação de ervas aromáticas congeladas, alho, chalota, caseína, ovos brancos, camarão congelado, aves, pernas de sapo congeladas e alimentos complementares (Food \& Water Watch, 2006).

- Reino Unido e Irlanda

O monitoramento da irradiação está tomando lugar na Europa, tanto o Reino Unido quanto o governo Irlandês informaram ter encontrado produtos irradiados ilegalmente em 2006.

Em fevereiro de 2006, a AEA Technology (AEAT), uma empresa que fazia parte da Autoridade de Energia Atômica do Reino Unido (UK Atomic Energy Authority), foi considerada culpada de uma série de falhas que levaram a um incidente de transporte de ${ }^{60} \mathrm{Co}$ há dois anos (Food Standards Agency, 2006).

$\mathrm{Na}$ Irlanda, todos os produtos irradiados foram retirados do mercado (Food Standards Agency, 2006)..

\section{AMÉRICA DO NORTE}

- Estados Unidos

Como o abastecimento de alimentos no mundo continua a se globalizar, com novos e exóticos frutos e vegetais que estão sendo introduzidos nos mercados estrangeiros quase diariamente, a necessidade de garantir a segurança da qualidade desses novos alimentos tornar-se de importância crítica. Em 2007, os 
Estados Unidos perdeu cerca de 34 milhões de libras por carne de bovino devido à E. coli, uma bactéria bacilar Gram-negativa. Como resultado, a idéia de segurança em alimentos nos mercados locais dos Estados Unidos também tem despertado uma atenção renovada (IMIP, 2006).

Embora a irradiação de alimentos ainda não seja amplamente adotada, já foi declarada como "segura e sã" pela Organização Mundial da Saúde (OMS) e pela Food and Drug Administration (USFDA).

Cerca de 40 países ao redor do mundo aprovaram o uso da irradiação para mais de 100 tipos de alimentos. Hoje, mais de 175 milhões de libras de especiarias e mais de 15 milhões de libras de carne de aves terrestres, são irradiadas todos os anos nos Estados Unidos (IMIP, 2006).

A recente legislação dos E.U.A. aprova a irradiação dos alimentos como um tratamento de quarentena de certos frutos importados, portanto a irradiação de alimentos se prepara para um crescimento substancial (MDS NORDION, 2008). A dose limite de radiação nos Estados Unidos é equivalente a mais de um bilhão de radiografias de tórax.

\section{OCEANIA}

- Austrália e Nova Zelândia

Alguns alimentos são aprovados para a irradiação na Austrália e na Nova Zelândia, são eles: ervas aromáticas, especiarias, infusões de plantas e cerca de nove frutas tropicais - manga, papaia, lichia, rambutão, manjar de maca, longans, carambolas, mangostão e fruta-pão. Também aprovados, mas não classificados como "alimentos", itens terapêuticos como: ervas, chás para 
infusões e outros bens terapêuticos, rações e grãos para animais (Food Irradiation Watch, 2006)

Os acordos de livre comércio com os Estados Unidos e China, a discrepância nos sistemas de regulação de todo o mundo, significa que, enquanto se esperar mais irradiação, a monitorização da irradiação manter-se-á difícil (Food Irradiation Watch, 2006).

\section{ÁFRICA}

- África do Sul

A África do Sul tem capacidade de produzir uma grande quantidade de frutas para exportação ao Reino Unido, União Européia e Estados Unidos. Sob novas regras dos E.U.A, a África do Sul pode exportar limões irradiados para os Estados Unidos. Cientistas sul-africanos também estão experimentando irradiar frutas cítricas, maçãs e pêras (IMIP, 2006).

Ainda é desconhecido o modo como os produtos irradiados serão amplamente aceitos e, se os distribuidores terão o compromisso de vendê-los. Transportes marítimos foram previstos para 2007, com a possível comercialização em 2008 (IMIP, 2006).

\subsection{Legislação}

A legislação brasileira segue as recomendações internacionais sugeridas pela Food and Agriculture Organization (FAO), International Atomic Energy 
Agengy (IAEA) e Codex Alimentarium, da Organização das Nações Unidas (ONU).

No Brasil, existe regulamentação sobre a irradiação de alimentos desde 1973 e portarias complementares foram editadas em 1985 e 1989 (Oliveira, 2000). A Portaria no 30 de 02/08/89, da Divisão de Alimentos do Ministério da Saúde, determinava o limite superior de irradiação de 10kGy, a lista de produtos aprovados para irradiação e suas respectivas doses proibia a re-irradiação. Em 26/01/2001, a Diretoria Colegiada da Agência Internacional de Vigilância Sanitária, (ANVISA), aprovou a Resolução (RDC) ㄲo 21, que não restringe quais alimentos podem ser irradiados e nem a dose máxima absorvida para se obter o fim desejado, desde que não haja prejuízo nas suas qualidades funcionais e sensoriais (EMBRARAD, 2003). Segundo a RDC no 21, qualquer alimento pode ser irradiado desde que sejam observadas as seguintes condições:

- a dose mínima absorvida deve ser suficiente para alcançar a finalidade pretendida;

- a dose mínima absorvida deve ser inferior àquela que comprometa as propriedades funcionais e/ou atributos sensoriais dos alimentos;

- a embalagem deve ter condições higiênicas aceitáveis para o processo de irradiação.

A RDC ํo 21 estabelece ainda que, quando um produto irradiado é usado como ingrediente em outro alimento, este fato deve ser mencionado na embalagem final com o símbolo da "radura" indicando que o alimento foi tratado por irradiação (FIGURA 1). No caso das especiarias este é um aspecto importante, desde que elas sejam utilizadas na fabricação de outros produtos, como os derivados de carne (Leal et al., 2004). 


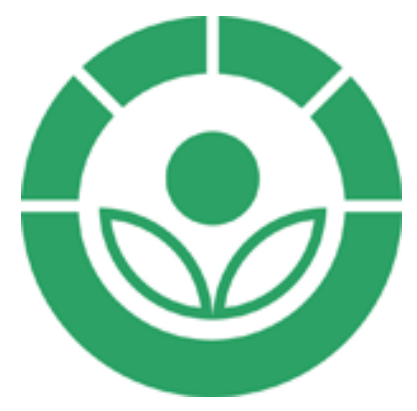

FIGURA 1 - Radura: símbolo utilizado em produtos irradiados

\subsection{Aceitação do Público}

Apesar de cientificamente aceito como um excelente método de conservação de alimentos e de atualmente ser o único capaz de tornar inativos os patógenos em alimentos crus e congelados, o progresso no uso comercial da irradiação tem sido lento. Interpretações errôneas dos consumidores, que freqüentemente acham difícil avaliar os benefícios dessa técnica de processamento e a falta de informações têm limitado o uso desta tecnologia (Ornellas et al., 2006).

Em função disso, atitudes deverão ser implementadas começando pela conscientização dos consumidores em relação à segurança e os benefícios obtidos por esta técnica e passando também por um estreitamento nas relações entre o governo e as indústrias do setor, que precisam ser fortalecidas. Para resultados mais eficazes, é preciso conhecer melhor o perfil dos segmentos envolvidos, por isso, sugere-se um levantamento desses dados utilizando-se recursos de pesquisas de campo (Ornellas et al., 2006).

A pesquisa de opinião é uma ferramenta bastante eficaz para detectar, com precisão, posições e tendências dos diversos segmentos sociais. Baseada em dados científicos, esta atividade é um excelente instrumento para identificar problemas e buscar soluções (Crowley et al., 2002) 
Uma pesquisa de opinião com consumidores feita por Ornellas e seus colaboradores em 2006, evidenciou que a falta de informação sobre a tecnologia da irradiação é um fator limitante do seu uso mais freqüente na indústria alimentícia brasileira, uma vez que $89 \%$ dos entrevistados consumiriam alimentos irradiados se soubessem que a irradiação aumenta a segurança alimentar contra inúmeras doenças (FIGURA 2). Este fato também foi constatado por Crowley, Gaboury e Witt em 2002, onde verificaram que quando há expectativa de benefícios para a saúde e os riscos são menores há maior disposição para compra.

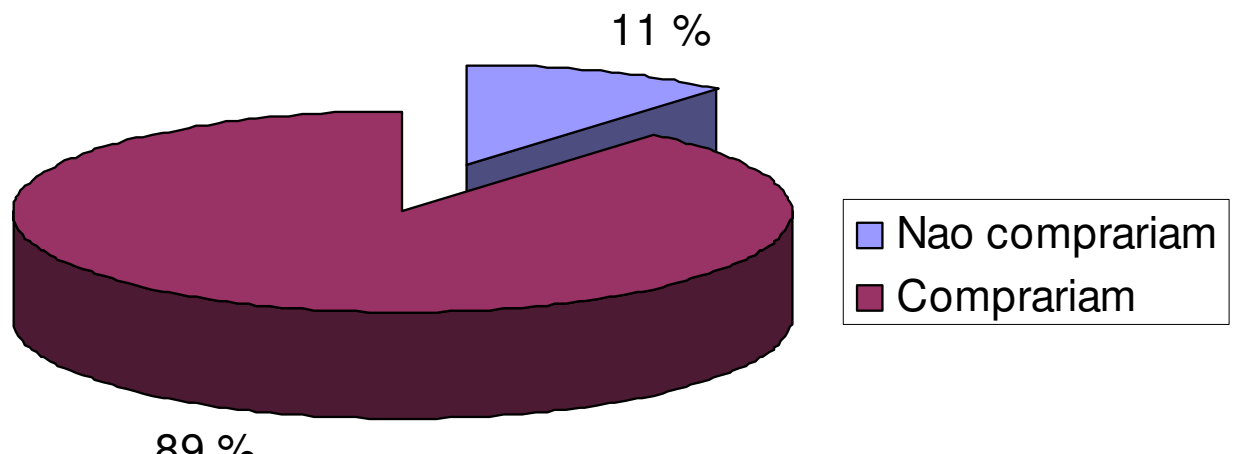

$89 \%$

FIGURA 2 - Atitude do consumidor frente à informação sobre produtos irradiados (Ornellas et al., 2006).

Para se ter uma idéia, Ressureccion e seus colaboradores em 1995, já haviam documentado que muitas pesquisas feitas nos Estados Unidos indicaram que a preocupação com a irradiação era menor do que sobre outras questões relativas aos alimentos, tais como aditivos alimentares, pesticidas, drogas e resíduos animais.

Fox em 2002 relatou que, fornecer informações científicas sólidas sobre a irradiação de alimentos reflete em uma boa aceitação por parte do consumidor, sendo, portanto, a acessividade ao conhecimento cientifico uma das causas da aceitação do público ter aumentado. Os estudos têm revelado a aceitabilidade 
variando de $45 \%$ a mais de $90 \%$, dependendo da forma com que essa tecnologia tão eficaz tem sido apresentada.

Em 2004, Nayga e seus colaboradores, também documentaram que os consumidores comprariam alimentos irradiados, dependendo do seu nível de preocupação e de sensibilização e, principalmente, a disponibilização de informações antecedentes suficientes.

Estes resultados enfatizam a importância de educar o público sobre a polêmica, a tecnologia, e os benefícios da irradiação em especial, levando em consideração que, por natureza, o ser humano se mostra mais receptivo aos argumentos negativos.

\subsection{Especiarias e ervas medicinais}

As especiarias são conceituadas como vegetais possuidores de substâncias aromáticas ou picantes de origem tropical usadas para dar sabores e odores aos alimentos, incluindo folhas, caules, flores e germinações, bulbos, rizomas, e outras partes das plantas (Bedin et al., 1999). Os componentes provedores de sabores existentes nas especiarias consistem de compostos como álcoois, ésteres, aldeídos, terpenos, fenóis, ácidos orgânicos e muitos outros elementos, que não tem sido totalmente identificados (Sagdic, 2002).

Por muito tempo as especiarias têm sido usadas como agentes provedores de caracteres organolépticos característicos aos alimentos aos quais são adicionadas. Porém, tem surgido um interesse voltado para o emprego destes agentes como promissores compostos antimicrobianos em sistemas de conservação de alimentos, sendo tal fato evidenciado frente a crescente disponibilidade de trabalhos científicos com ênfase em tal assunto (El-Shami et al., 1985; Akgul E Kivanc, 1988; Cossetino et al., 1999; Doman e Deans, 2000; 
Ristori et al., 2002; Radhakrishanan-Sridhar e Velusamy-Rajaopal, 2003). As plantas aromáticas e as especiarias são ricas em óleos essenciais caracterizados por uma notável atividade antimicrobiana, e por esta razão, seus produtos derivados podem ser usados para retardar ou inibir o crescimento de microrganismos patogênicos e/ou deteriorantes (Marino et al., 2001)

Embora possam ou não contribuir com o valor nutricional de uma dieta, as especiarias podem ser fontes de antioxidante natural relevante, desde que sejam utilizadas tradicionalmente como ingredientes, o que permite que sejam facilmente e diretamente empregadas por suas propriedades antioxidantes em alimentos e possivelmente em outros sistemas (Lee et al., 2003).

Com o intuito de analisar os voláteis formados pela irradiação de ervas alimentícias e medicinais e, as posteriores mudanças sensoriais dessas ervas após o tratamento com radiação e estocagem, se fazem importantes os conceitos das amostras que foram utilizadas no presente trabalho.

\section{Laurus Cinnamomum (nome popular: canela)}

A família Lauraceae é considerada uma das famílias mais primitivas pertencentes à divisão Magnoliophyta. Tal fato se deve às suas características morfológicas e anatômicas que as aproxima de outras famílias como Calycanthaceae, Idiospermaceae e Hernandiaceae (Cronquist, 1988). As Lauraceae apresentam-se amplamente distribuídas nas regiões tropicais e subtropicais do planeta, sendo formadas por 49 gêneros e 2.500 - 3.000 espécies (Werff \& Richter, 1996). Os primeiros registros relativos à utilização das espécies desta família datam de 2.800 a.C, sendo originários da Grécia antiga. Isso influenciou o nome de muitos gêneros que fazem uma alusão àquela época. Laurus Cinnamomum, por exemplo, é derivado da palavra indonésia "kayu manis", que significa "madeira doce". Mais tarde, recebeu o nome hebreu "quinnamon", que evoluiu para o grego "kinnamon". Outras espécies utilizadas 
desde a Grécia antiga são as pertencentes ao gênero Cinnamomum Schaeffer, que significa "caneleira” em grego (Barroso et al., 1978; Coe-Teixeira, 1980).

As Lauraceae destacam-se entre as demais famílias pela sua importância econômica. Algumas espécies têm sido utilizadas pelas indústrias. As espécies aromáticas e as que produzem óleos, como a Cinnamomum Zeylanicum, alcançam valor alto no mercado, pois são frequentemente usadas como fonte de matérias-primas em indústrias (Barroso et al., 1978).

Os óleos essenciais mais importantes no mercado mundial são os obtidos de C. Verum ("cinnamomum bark oil" e "cinnamomum leaf oil"), C. Cassia ("cassia oil") e C. Camphora ("sassafras oil" e "ho leaf oil"). Cinnamomum Zeylanicum Blume (Cinnamomum verum J. S. Presl.), conhecida como "canela-da-índia" e "canela-do-ceilão", é originária de algumas regiões da Índia e do Ceilão, atual Sri Lanka (Lima et al., 2005)

Neste trabalho estudaremos o gênero Cinnamomum Zeylanicum que é o mais comercializado ultimamente (FIGURA 3). Ela apresenta várias finalidades, sendo utilizada na agricultura para controle de nematóides; fungicida; cosméticos; culinária e na medicina (Morsbach, 1997).
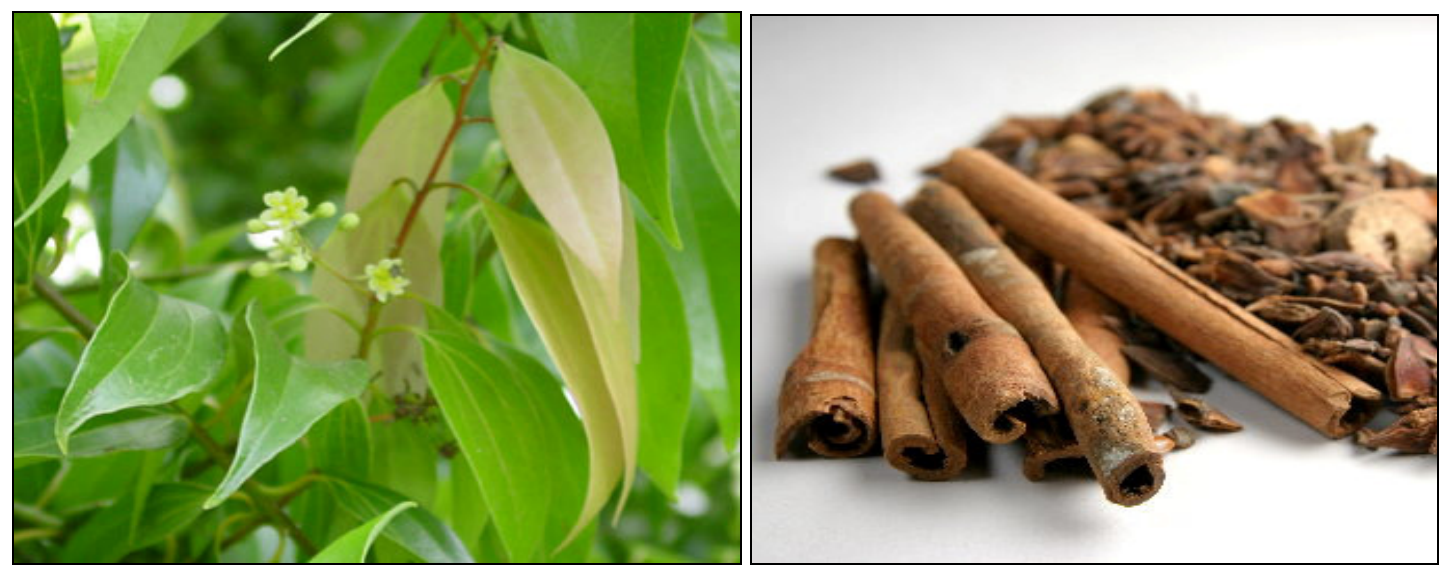
FIGURA 3 - Caneleira e Canela

Seus efeitos medicinais são diversos, apresenta função adstringente, afrodisíaca, anti-séptica, hipertensora, sedativa, tônica, aperiente, aromática, carminativo, estimulante, digestiva e vasodilatadora (Morsbach, 1997). A canela e o seu óleo essencial são empregados também como corretivos do odor e do sabor na preparação de alguns medicamentos (Costa, 1997).

A canela em pó requer matéria-prima de boa qualidade, assim como manipulação, embalagem e armazenamento adequados, para garantir sua pureza e características inconfundíveis (Philippi et al., 1995).

Myristica Fragans (nome popular: noz-moscada)

Pertencente à família das Myristicaceae, a noz-moscada (FIGURA 4) originária das Ilhas Molucas, na Indonésia e em seguida introduzida na Índia, comumente usada foi colocada no ocidente pelos árabes, logo se tornando, junto com a páprica uma das especiarias mais caras e procuradas. É comercializada, principalmente na Europa como condimento na indústria frigorífica, na indústria farmacêutica, na perfumaria e tabacaria. Anualmente se comercializa com os países da Europa e Oriente Médio, cerca de 10 mil toneladas anuais no valor de 30 milhões de dólares, o que atende apenas a 50\% das necessidades do mercado mundial (Fraipe, 2002).

Sua composição química é bastante variável, em média contém: 9,0\% de água; $96,5 \%$ de compostos nitrogenados; $33 \%$ de gorduras; $4,5 \%$ óleos essenciais; 27 \% de amido; 14,5\% de extratos não nitrogenados; 3\% de celulose e $2,5 \%$ de cinzas (Fraipe, 2002). 
Os principais países produtores são: Indonésia, Índia, Nova Guiné, Ceilão, Zanzibar, Trinidad, Tailândia. Já os principais compradores são: Inglaterra, França, Canadá, Estados Unidos. Japão, China e Austrália (Farrel, 1998).
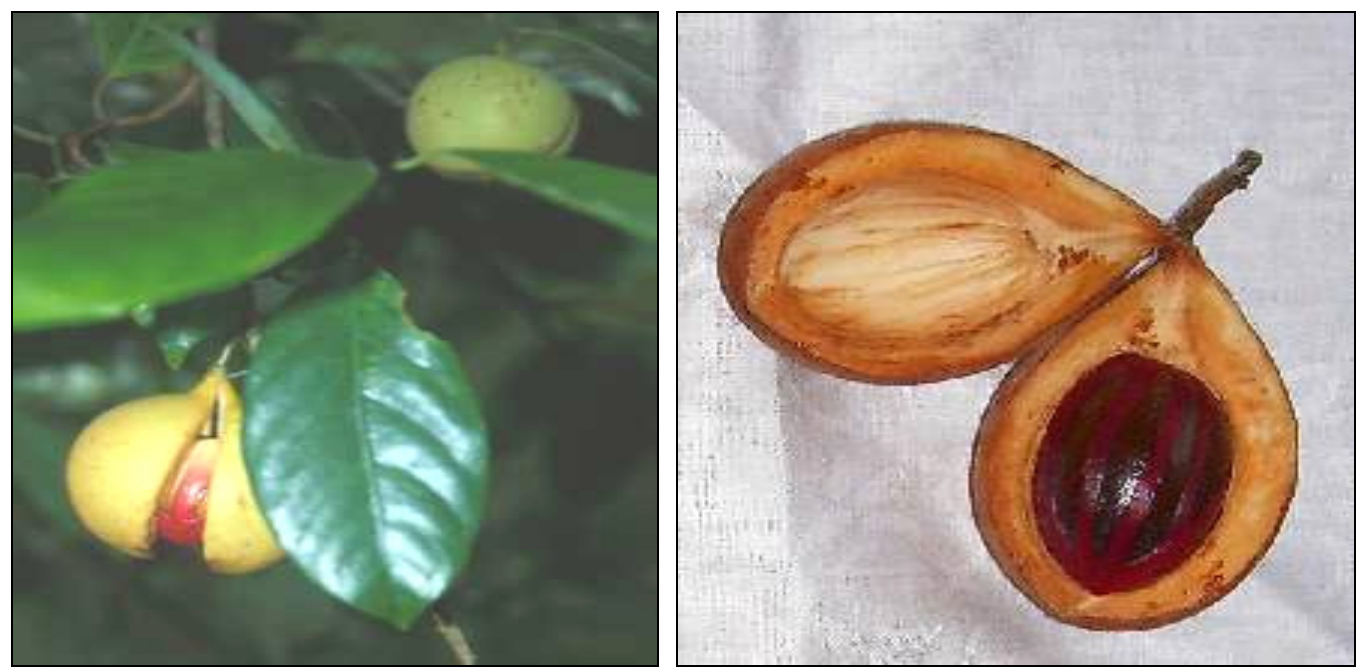

FIGURA 4 - Noz-moscada

A noz-moscada apresenta efeitos medicinais do tipo analgésico, antiespasmódico, antiemético, afrodisíaco, carminativo e laxativo (Fraipe, 2002).

Origanum Vulgare (nome popular: orégano)

Pertencente à família Lamiaceae, o gênero origanum é uma erva perene na forma de arbusto e nativa das regiões Euro-Siberiana e Irano-Siberiana, sendo atualmente reconhecida 38 espécies deste gênero no mundo (Aligianis et al., 2001). Devido sua ampla variedade de características químicas e de aroma, diferentes espécies e biótipos de origanum são amplamente utilizados como 
insumo na indústria farmacêutica e cosmética, como erva culinária, como flavorizante de alimentos, em bebidas alcoólicas e em perfumaria na obtenção e fragrâncias picantes (Sivropoulou et al., 1996; Novack et al., 2000; Aligianis et al., 2001).

As folhas secas e o óleo essencial de Origanum Vulgare (FIGURA 5) têm sido usados medicinalmente por vários séculos em diferentes partes do mundo, e seu efeito positivo sobre a saúde humana tem sido atribuído à presença de propriedades antimicrobianas (Leung e Foster, 1996; Milos et al., 2000) e de compostos antioxidantes na erva e conseqüentemente em seus produtos derivados (Peak et al., 1991; Cervato et al., 2000). Suas propriedades biológicas podem variar de acordo com a técnica de cultivo, origem, estágio vegetativo e estação de coleta do material vegetal (Leung e Foster, 1996; Milos et al., 2000).
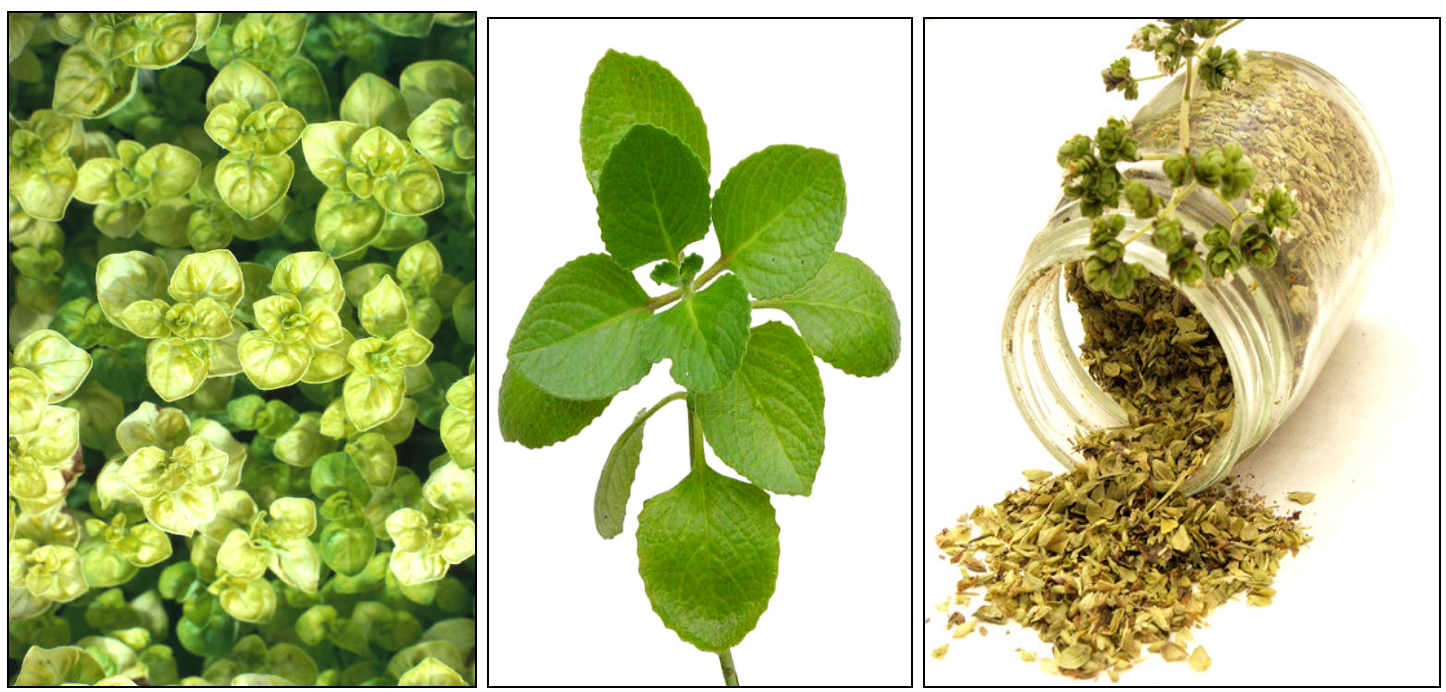

FIGURA 5 - Orégano

Marino e seus colaboradores em 2001, analisando o efeito antimicrobiano de várias especiarias, notaram que o óleo essencial de orégano foi o mais efetivo 
na inibição de bactérias Gram- positivas e Gram-negativas. Ademais, tal produto apresentou-se como eficiente substância bactericida, detectado pela não recuperação de tais microrganismos após reincubação em meio de recuperação.

O estudo da atividade antibacteriana do orégano e de seus diferentes extratos e óleo essencial também têm sido executados sobre bactérias e fungos patogênicos e deteriorantes. Sahin et al. (2003) conduziram um estudo para avaliar a efetividade antibacteriana do extrato metanólico e do óleo essencial de orégano sobre uma série de bactérias de interesse em alimentos e observaram que o óleo essencial foi efetivo na inibição da grande maioria das bactérias ensaiadas, a citar Acinetobacter baumanii, Bacillus macerans, Bacillus subtillis, B. megantertium, Clavibacter michiganense, Enterococcus faecalis, Escherichia coli, Proteus vulgaris, Staphylococcus aureus e Streptopcoccus pyogenes. Os autores ainda relatam que seus achados suportam as observações de estudos prévios que evidenciaram que o óleo essencial de orégano possui compostos com potencial antibacteriano (Zargari, 1990; Leung e Foster, 1996).

Sagdiç (2002) avaliou a ação inibitória do hidrossol de orégano sobre bactérias patogênicas, e observou sua efetividade na inibição de Staphylococcus aureus, E. coli e Yersinia enterocolitica. O hidrossol nas concentrações de 10 e $25 \mathrm{~mL} / 100 \mathrm{~mL}$ foi bacteriostático, enquanto que nas concentrações de 50 e $75 \mathrm{~mL} / 100 \mathrm{~mL}$ teve ação bactericida. Koutsoumanis et al. (1999) observaram uma inibição da população de Salmonella enteridis em refeição tipo salada conseqüente à adição de óleo essencial de orégano em várias concentrações, sendo tal efeito causador de redução da população deste microrganismo de até 6 ciclos logarítmicos após 7 dias de incubação a $20^{\circ} \mathrm{C}$.

São inúmeros os estudos que comprovam a eficácia do orégano como antimicrobiano, Daferera et al. (2000) encontraram efetividade no óleo essencial de orégano para inibir o total crescimento de Botrytis cinerea e Fusarium sp. E enfatizam que tais fungos são importantes agentes envolvidos em perdas de 
culturas conseqüentes de sua ação patogênica sobre o vegetal, sendo os resultados obtidos em sua pesquisa um possível passo para aplicação de óleos essenciais no controle de microrganismos fitopatógenos. Bassílico e Basílico (1999) também verificaram a eficiência antifúngica do óleo essencial de orégano (100 ppm) através da inibição do crescimento micelial de Aspergillus ochraceus e produção de ocratoxina A por tal fungo.

Origanum Vulgare apresenta outros efeitos medicinais do tipo digestivo, estimulante, enemagoga, diurético, sedativo, expectorante e de função sudorífera (Sagdiç, 2002).

Piper Nigrum (nome popular: pimenta-do-reino)

Originária do sudeste asiático, a pimenta-do-reino (FIGURA 6), família Piperaceae, apresenta inflorescência em forma de espiga, chamada amentilho, e é composta de pequenas flores desprovidas de cálice e corola. Os frutos são globosos, pequenos e indeiscentes, apresentando cor verde-escura quando imaturos. adquirindo coloração escura quando maduros. As pimenteiras adultas podem atingir mais de $3 \mathrm{~m}$ de comprimento e, por serem plantas trepadeiras perenes, necessitam de suportes (tutores) para um bom desenvolvimento. Cultivada tanto nas regiões litorâneas como no planalto, necessita de precipitação pluviométrica de $1.800 \mathrm{~mm} / \mathrm{ano}$, temperatura média de $21^{\circ} \mathrm{C}$ e umidade relativa em torno de $80 \%$ (Secretaria da Agricultura, SP. 1987). 

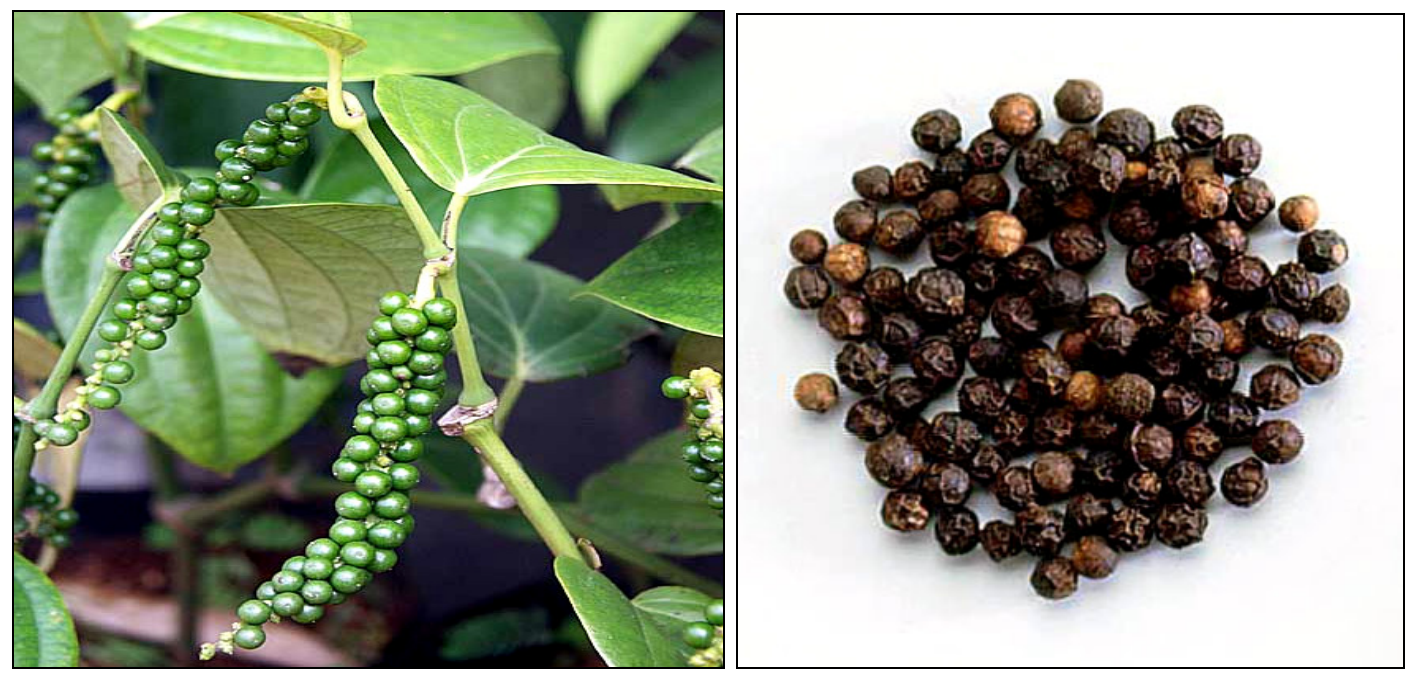

FIGURA 6 - Pimenta-do-reino

As sementes da pimenta-do-reino encerram uma resina, à qual se devem seu sabor picante e um óleo essencial de cheiro muito ativo com teor alto de uma substância chamada piperina (Correa, 1984). Essas sementes inteiras ou moídas são utilizadas como condimento e preservadoras de carne nas indústrias de conservas, e os óleos essenciais extraídos das sementes são empregados em perfumaria (Secretaria de Agricultura, SP. 1987).

Formulações derivadas das sementes de pimenta-do-reino são muito eficientes no controle de pulgões, ácaros e cochonilhas em plantas medicinais (Burg \& Mayer, 1999).

A pimenta-do-reino é, também, extremamente importante como planta medicinal. As sementes são usadas como tônico, sudorífero e estimulante. Em pequenas doses, facilita a digestão e é aconselhada nas febres intermitentes rebeldes e na cólera. Em solução alcoólica ou fervida em azeite é um linitivo rubefaciente, aplicável nas dores reumáticas e paralisias. Utilizada em doses mínimas, a pimenta-do- reino possui ação excitante sobre os órgãos digestivos (Almeida, 1993; Editora Abril, 1991). 
O Brasil é um dos maiores produtores de pimenta-do-reino, oscilando entre a segunda e terceira posição no mercado mundial. Das 50 mil toneladas por ano, o País exporta 45 mil, principalmente para a Europa e para os Estados Unidos, sendo a mais importante especiaria comercializada mundialmente, é usada em grande escala como condimento e também em indústrias de carnes e conservas (Perez, 2007).

\subsection{História das Especiarias}

A história das especiarias e do comércio das especiarias foi marcada por longas batalhas, lutas de poder, conquistas, intrigas - todos os elementos de uma história violenta (Farrel, 1998).

As especiarias foram uma mercadoria muito valiosa e como conseqüência disto, o comércio era muito competitivo (Farrel, 1998).

As ervas e especiarias não foram apenas utilizadas para alimentação, mas também na medicina para curar doenças. Acredita-se que a prática da utilização de ervas com intuito medicinal teve início há mais de 5.000 anos atrás por um imperador Chinês chamado Fo Hi.

O papiro egípcio, escrito por volta do ano 3000 a.C é o mais antigo manuscrito conhecido, explicando como curar doenças por meio das especiarias (Farrel, 1998).

As ervas e especiarias foram também utilizadas para aquisição de riquezas, para embalsamar e enterrar mortos e, como afrodisíacos. O Rei Salomão, o mais rico e prudente de todos os reis, adquiriu boa parte de sua riqueza por meio das especiarias (Farrel, 1998). Uma citação bíblica relata tal ocasião: 
"E quando a rainha de Sabá (região agora conhecida como Lemên) veio a Jerusalém com um mui grande exército, com camelos carregados de especiarias, e muitíssimo ouro, e pedras preciosas; e veio Salomão e disse-lhe tudo quanto tinha no seu coração. $E$ deu ao rei cento e vinte talentos de ouro, e muitíssimas especiarias, e pedras preciosas; nunca veio especiaria em tanta abundância como a que a rainha de Sabá deu ao rei Salomão" (I Reis 10: 2 e 10).

A primeira referência do comércio de especiarias é encontrado na Bíblia, mais precisamente em Gênesis 37:25-36. Alguns historiadores calculam ser por volta do ano 1729 a.C. (Farrel, 1998).

“Depois assentaram-se a comer pão, e levantaram os olhos, e olharam, e eis que uma companhia de ismaelitas vinha de Gileade; e seus camelos traziam especiarias, e bálsamo, e mirra; e iam levar isso ao Egito."

Os ismaelitas eram comerciantes árabes que faziam o transporte de especiarias por milhares de quilômetros através de camelos e navios, da Índia, Birmânia, e Península da Malásia, e a área do Golfo Pérsico para o centro comercial de Alexandria e Carthage, no oeste. Suas viagens demoravam de quatro a cinco anos (Farrel, 1998).

Há mais de sessenta outras referências no velho testamento relatando o elevado apreço pelas especiarias. Há também numerosos registros históricos escritos pelos renomados historiadores como Heródoto (484 - 243 a.C.); Hipócrates (477 - 360 a.C), o pai da medicina moderna; Theophrastus (372 287 a.C), considerado por muitos ser o pai da botânica; Plínio, o velho (62 - 110 d.C), o maior escritor do reinado de Vespasiano, cujo zelo pela verdade científica e pela pesquisa causou sua morte; e Publius Cornelius Tacitus (55-117 d.C.), um importante historiador de Roma que documentou práticas comerciais dos mercadores árabes de especiarias entre o Oriente e o Ocidente até a era Cristã. 
Cada um contribuiu muito para a intrigante história das especiarias (Farrel, 1998).

Desde o século sexto d.C, os comerciantes árabes dominaram a embarcação de especiarias para a China, Indonésia, Ceilão, índia, Península da Malásia e outras nações orientais que tiveram o crescimento de especiarias, tais como Egito, Grécia, Itália, e ocidente, quer transportadas por barcos, camelos ou jangadas. Parte da grande riqueza de Veneza teve origem no comércio de especiarias na índia, Ceilão (atual Sri Lanka), Índia Oriental, e Cathay (China) obtidas em Alexandria e vendidas no norte e oeste europeu por compradores/distribuidores a preços exorbitantes. Na FIGURA 7, podemos observar fardos de canela prontas para exportação.

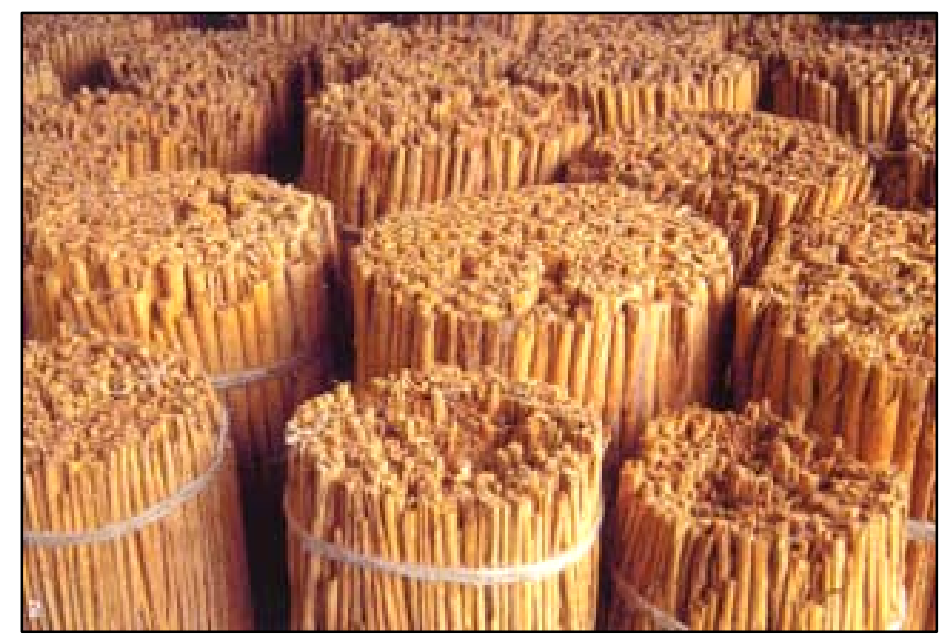

FIGURA 7 - Fardos de canela prontos para exportação

A procura por especiarias cresceu tão rapidamente quanto a população, e isso não foi muito tempo antes do comércio de especiarias ser dominado pelos Estados Unidos. Atualmente, o centro comercial de especiarias centra-se na área de Wall Street, na cidade de Nova lorque, com um volume substancial de 
especiarias abrangendo os portos da Costa Oeste de São Francisco e Los Angeles.

As especiarias são normalmente transportadas para os Estados Unidos em diversas formas: em extratos, óleos, oleorresinas, também são importadas em grandes quantidades. As especiarias importadas são inspecionadas pelo FDA (Food and Drug Administration) no próprio cais ou embarcadouro e temporariamente no estabelecimento comercial pelo importador até a venda para empresas de especiarias espalhadas pelo País (Perez, 2007).

As empresas de especiarias submetem seu produto à limpeza, moagem, extração, composição, mistura, ou reembalagem em pequenos recipientes de distribuição varejista (Farrel, 1998)

A maioria das especiarias tropicais ainda provém do hemisfério Oriental, como vem sendo feito há séculos, mas a América Central e a América do Sul, assim como o oeste indiano, estão contribuindo em quantidades significativas de qualidade alta para o mercado mundial de especiarias.

A importação de especiarias nos Estados Unidos subiu 11\% de 240 milhões lb (10,9 milhões Kg) em 1979 para 266 milhões lb (12,9 milhões Kg) em 1983, mas o dólar decresceu $11 \%$. O valor médio de todas as especiarias no mercado mundial caiu cerca de \$1.28 para 1.03 por Kg em 1998 (Perez, 2007).

Em peso, o Canadá aparece como o principal país de importação de especiarias, mas o valor baixo da semente de mostarda responde por $99 \%$ dos negócios. Financeiramente, a Indonésia representa $22 \%$ do total, o Brasil é segundo com 13\%, e Canadá, Índia, e Espanha são aproximadamente iguais com um pouco mais que $8 \%$ cada (TABELA 4). 
A pimenta branca e preta são de longe os principais tipos de especiarias importadas, seguida pela semente de mostarda, capsicum, cássia, paprika, coentro, gengibre e orégano. Estas nove especiarias representam cerca de $75 \%$ do peso e $63 \%$ do valor de importação das especiarias. É de interesse notar que as especiarias "quentes", compreendendo mostarda, pimenta, capsicum, e gengibre, representam $80 \%$ desta tonelagem e $70 \%$ do valor para estas nove especiarias (Perez, 2007).

As exportações brasileiras do grupo de especiarias evoluíram em volume físico, em mais de $100 \%$ de 1996 a 2004, quando ficaram muito próximas das 100 mil toneladas. Nos anos seguintes, as quantidades ficaram pouco abaixo desse patamar. Em valor monetário a evolução das exportações foi menos acentuada, passando de US\$107 milhões em 1996 para US\$171 milhões em 2006 (TABELA 4). A evolução ocorrida pode ser explicada, em parte, pela diversificação da pauta de comércio externo do grupo estudado e, principalmente, pela maior participação relativa de canela, cravo-da-índia, nozmoscada e, pimentões e pimentas preparados (Perez, 2007). 
TABELA 4 - Exportações brasileiras de algumas especiarias de 1997 a 2007

\begin{tabular}{|c|c|c|c|c|c|c|c|c|c|c|c|c|c|}
\hline \multirow[t]{2}{*}{ Mercadoria } & \multicolumn{11}{|c|}{ Peso líquido (em t) } & \multicolumn{2}{|c|}{ Part (\%) } \\
\hline & 1997 & 1998 & 1999 & 2000 & 2001 & 2002 & 2003 & 2004 & 2005 & 2006 & 2007 & 1997 & 2006 \\
\hline Canela & 0 & 0 & 10 & 3 & 261 & 2.942 & 2.239 & 2.256 & 2.321 & 2.850 & 182 & 0 & 3 \\
\hline $\begin{array}{l}\text { Cravo-da- } \\
\text { índia }\end{array}$ & 138 & 184 & 460 & 65 & 2.487 & 4.135 & 2.598 & 6.211 & 2.107 & 3.533 & 1.146 & 0 & 4 \\
\hline $\begin{array}{l}\text { Demais } \\
\text { especiarias }\end{array}$ & 64 & 6 & 2 & 10 & 4 & 376 & 908 & 923 & 759 & 863 & 185 & 0,2 & 0,9 \\
\hline $\begin{array}{l}\text { Noz- } \\
\text { moscada }\end{array}$ & 0 & 0 & 0 & 0 & 0 & 0 & 196 & 474 & 549 & 1.490 & 0 & 0 & 1,5 \\
\hline $\begin{array}{l}\text { Pimenta } \\
\text { piper seca }\end{array}$ & 13.962 & 17.249 & 19.617 & 20.449 & 36.975 & 38.230 & 38.972 & 43.003 & 38.424 & 42.200 & 13.395 & 29 & 43 \\
\hline Pimentões & 66 & 547 & 3.848 & 4.072 & 6.171 & 6.085 & 6.503 & 8.391 & 8.498 & 4.604 & 2.007 & 0 & 5 \\
\hline Outros & 1 & 0 & 0 & 2 & 1 & 1 & 4 & 51 & 196 & 2 & 0 & 0 & 0 \\
\hline \multirow[t]{2}{*}{ Mercadoria } & \multicolumn{11}{|c|}{ Valor (em US\$1.000) } & \multicolumn{2}{|c|}{ Part (\%) } \\
\hline & 1997 & 1998 & 1999 & 2000 & 2001 & 2002 & 2003 & 2004 & 2005 & 2006 & 2007 & 1997 & 2006 \\
\hline Canela & 3 & 5 & 8 & 11 & 318 & 3.535 & 2.723 & 3.399 & 3.446 & 3.973 & 221 & 0 & 2 \\
\hline $\begin{array}{l}\text { Cravo-da- } \\
\text { índia }\end{array}$ & 113 & 172 & 946 & 267 & 14542 & 23422 & 4609 & 13568 & 5932 & 11441 & 3557 & 0,1 & 6,7 \\
\hline $\begin{array}{l}\text { Demais } \\
\text { especiarias }\end{array}$ & 134 & 21 & 3 & 35 & 45 & 990 & 2.123 & 1.563 & 1.637 & 2.159 & 452 & 0 & 1 \\
\hline $\begin{array}{l}\text { Noz- } \\
\text { moscada }\end{array}$ & 0 & 0 & 0 & 1 & 2 & 1 & 1.416 & 3.578 & 5.641 & 13.064 & 0 & 0 & 8 \\
\hline $\begin{array}{l}\text { Pimenta } \\
\text { piper seca }\end{array}$ & 59.376 & 77.670 & 87.448 & 69.152 & 59.677 & 59.466 & 58.771 & 65.073 & 56.245 & 85.278 & 33.419 & 56 & 50 \\
\hline Pimentões & 19 & 1.100 & 8.252 & 8.992 & 12.567 & 12.329 & 13.516 & 17.254 & 23.076 & 11.794 & 5.388 & 0 & 7 \\
\hline Outros & 2 & 1 & 1 & 10 & 2 & 2 & 15 & 51 & 1.489 & 8 & 0 & 0 & 0 \\
\hline
\end{tabular}

Fonte - Perez, 2007.

A pimenta-do-reino teve grande aumento na quantidade exportada (cerca de 14 mil toneladas em 1996 para um patamar próximo a 40 mil toneladas a partir de 2002) o que elevou sua participação relativa de 28,5\% (1996) para 43,3\% 
(2006). Por outro lado, a mercadoria teve redução na importância relativa no valor exportado (de 55,6\% para 49,8\%, no mesmo período), devido à queda de preços de US\$ 4.25/kg em 1996 para US\$2.02/kg em 2006, que reduziu o impacto do aumento da quantidade no comércio externo da pimenta-do-reino. Finalmente, o subgrupo composto por canela, cravo-da-índia, noz-moscada e, pimentões e pimentas preparados aumentou sua participação relativa de $0,4 \%$ (1996) para $12,8 \%$ (2006) na quantidade e de $0,1 \%$ para $23,5 \%$ no valor total exportado pelo grupo no período (TABELA 4). A projeção simplista dos dados iniciais de 2007 indica um desempenho bem inferior ao do ano de 2006 principalmente para canela, noz-moscada e cravo-da-índia (Perez, 2007).

\subsection{Irradiação de especiarias}

Mesmo sendo utilizadas em pequenas quantidades, as especiarias, apresentam um potencial forte de contaminação microbiológica para os alimentos nos quais são adicionadas (Sádecká, 2007).

Frequentemente as especiarias são originárias de países desenvolvidos, onde a colheita $e$ as condições de armazenagem são controladas inadequadamente no que se diz respeito à higiene alimentar. Com isso, ocorre uma exposição a um alto nível de contaminação natural por bactérias mesófilas, esporogênicas e não esporogências, fungos e coliforme fecais (Sádecká, 2007). Microorganismos de grande preocupação para a saúde pública tais como Salmonella, Escherichia coli, Clostridium perfringens, Bacillus cereus, e fungos toxicogênicos também podem estar presentes. Para se ter uma noção, contagens de placa bacteriana indicando cerca de 100 milhões por grama de especiaria é considerado habitual (Bendini et al., 1998). Num processo onde tantas especiarias são muito contaminadas por microorganismos, é de 
importância crescente que a contaminação microbiana não deve exceder um limite aceitável de $10^{4}$ organismos $^{-1}$ (Farkas, 1987).

Boas práticas de fabricação de processamento durante a colheita poderiam melhorar a qualidade higiênica das especiarias, mas não seria o suficiente para se obter um grau aceitável de pureza microbiológica (Who, 1999). Ingredientes de plantas secas contaminadas causam sérios problemas na indústria de alimentos.

Especiarias, ervas e vegetais secos são atualmente tratados com radiação ionizante para eliminação da contaminação microbiana. Foi confirmado que o tratamento com energia ionizante é mais eficaz contra bactérias do que tratamentos térmicos (Tjaberg et al., 1972; Loaharanu, 1997; Thayer et al., 1996; Olson, 1998).

Normalmente as especiarias são tratadas com dose de radiação variando de 5 a 17kGy. Ademais, as especiarias são usualmente irradiadas na embalagem final para prevenir contaminação posterior. Neste caso, possíveis compostos anormais do material da embalagem podem ser criados pela irradiação e talvez migrar para o alimento. Conseqüentemente, essa migração pode ser potencialmente perigosa e impactar significativamente no sabor do alimento (Lee et al., 2004) 


\section{MATERIAL E MÉTODOS}

\subsection{Materiais}

As amostras de canela (Laurus Cinnamomum), pimenta-do-reino (Piper Nigrum), orégano (Origanum Vulgare) e noz-moscada (Myristica Fragans) analisadas, foram fornecidas pela Hikari Indústria e Comércio Ltda. As amostras enviadas pela mesma não foram previamente submetidas à qualquer dose de radiação e isentas de qualquer outro tratamento de conservação . Na TABELA 5 são apresentadas a maneira como as amostras foram organizadas.

\section{TABELA 5 - Organização das amostras}

\begin{tabular}{lccccc}
\hline Especiaria & 0 kGy & 10kGy & 15kGy & 20kGy & 25kGy \\
\hline Canela & 6 & 6 & 6 & 6 & 6 \\
Pimenta-do-reino & 6 & 6 & 6 & 6 & 6 \\
Orégano & 6 & 6 & 6 & 6 & 6 \\
Noz-moscada & 6 & 6 & 6 & 6 & 6 \\
Total: & 36 & 36 & 36 & 36 & 36 \\
\hline
\end{tabular}

\subsection{Preparação das Amostras}

\subsubsection{Especiarias}

Foram pesadas e embaladas em sacos plásticos 6 amostras de cada condição das determinadas especiarias, na qual cada embalagem continha aproximadamente $1 \mathrm{~g}$ de especiaria. As embalagens foram seladas e enviadas para irradiação. 


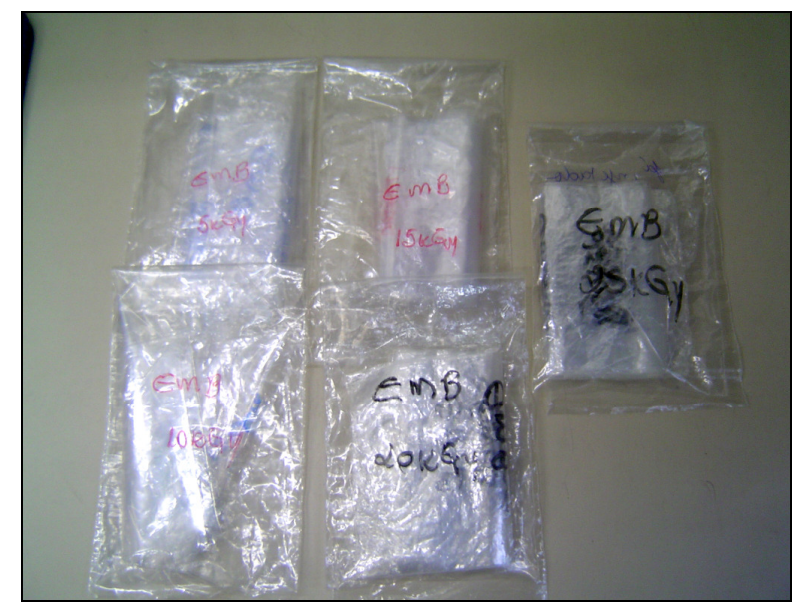

FIGURA 8 - Embalagens plásticas das especiarias

\subsubsection{Embalagens}

Foram feitas análises individuais das embalagens em que as especiarias foram irradiadas. As embalagens foram seladas em uma seladora para plásticos, utilizada também na indústria e, em seguida, enviadas para irradiação.

\subsection{Irradiações}

As irradiações foram feitas no irradiador Gammacell de ${ }^{60} \mathrm{Co}$, no CTR (Centro de Tecnologia das Radiações) IPEN-CNEN/SP, com taxas de dose apresentadas na TABELA 6. 
TABELA 6 - Taxas de dose do irradiador no período utilizado.

\begin{tabular}{c|c}
\hline Taxa de dose & $\begin{array}{c}\text { Taxa de dose } \\
\text { média }\end{array}$ \\
\hline $2,62 \mathrm{kGy} / \mathrm{h}$ & \\
$2,69 \mathrm{kGy} / \mathrm{h}$ & $2,63 \mathrm{kG} / \mathrm{h}$ \\
$2,60 \mathrm{kGy} / \mathrm{h}$ & \\
\hline
\end{tabular}

Foram utilizadas as doses de 0, 5, 10, 15, 20 e 25kGy tanto para irradiar as especiarias quanto para as embalagens individuais. As amostras secas das especiarias foram processadas nas embalagens plásticas de polipropileno que são recomendadas e utilizadas para embalar especiarias.

\subsection{Técnica de Microextração em Fase Sólida (SPME - Solid Phase Microextraction)}

O método de extração de voláteis empregou a técnica de microextração em fase sólida com uma resina de polidimetilsiloxano de $100 u \mu$ de espessura da Supelco, empregando o aparato da mesma empresa para este tipo de extração. Esta combina amostragem e pré-concentração dos analíticos num único processo, além de possibilitar a dessorção direta no sistema cromatográfico. As amostras das especiarias foram analisadas dentro do prazo de uma semana após irradiação.

As amostras controle e irradiadas foram pesadas novamente num erlenmeyer de $25 \mathrm{ml}$, em que se manteve a quantidade de aproximadamente $1 \mathrm{~g}$ de cada e foram vedados com septos de borracha (FIGURA 9). 

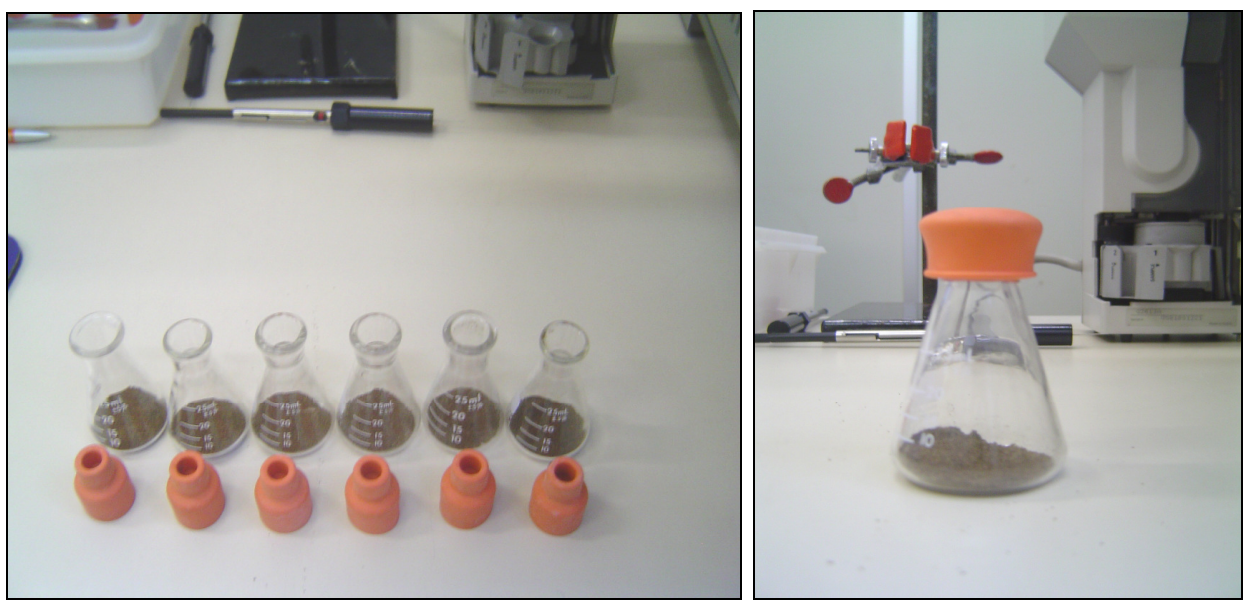

FIGURA 9 - Amostras prontas para serem analisadas

O erlenmeyer foi aquecido à $50^{\circ} \mathrm{C}$ dentro do forno do cromatógrafo à gás durante 5 minutos (FIGURA 10), para a suspensão do aroma da especiaria e também dos voláteis emitidos pelas embalagens analisadas individualmente. $A$ fibra previamente limpa no injetor do $\mathrm{CG} / \mathrm{MS}$ à $200^{\circ} \mathrm{C}$ durante 4 minutos foi exposta ao erlenmeyer através da seringa do holder (FIGURA 11), perfurando a vedação de borracha do erlenmeyer. O tempo de exposição da resina aos voláteis emitidos pelas especiarias e pelas embalagens foi de 15 minutos cada.

Para expor a fibra aos voláteis emitidos pelas embalagens foi utilizado uma agulha convencional esterilizada para a perfuração da vedação de borracha e também da embalagem selada dentro do erlenmeyer (FIGURA 12). Tal procedimento foi utilizado para que não se perdesse compostos voláteis da embalagem antes da exposição à fibra. 

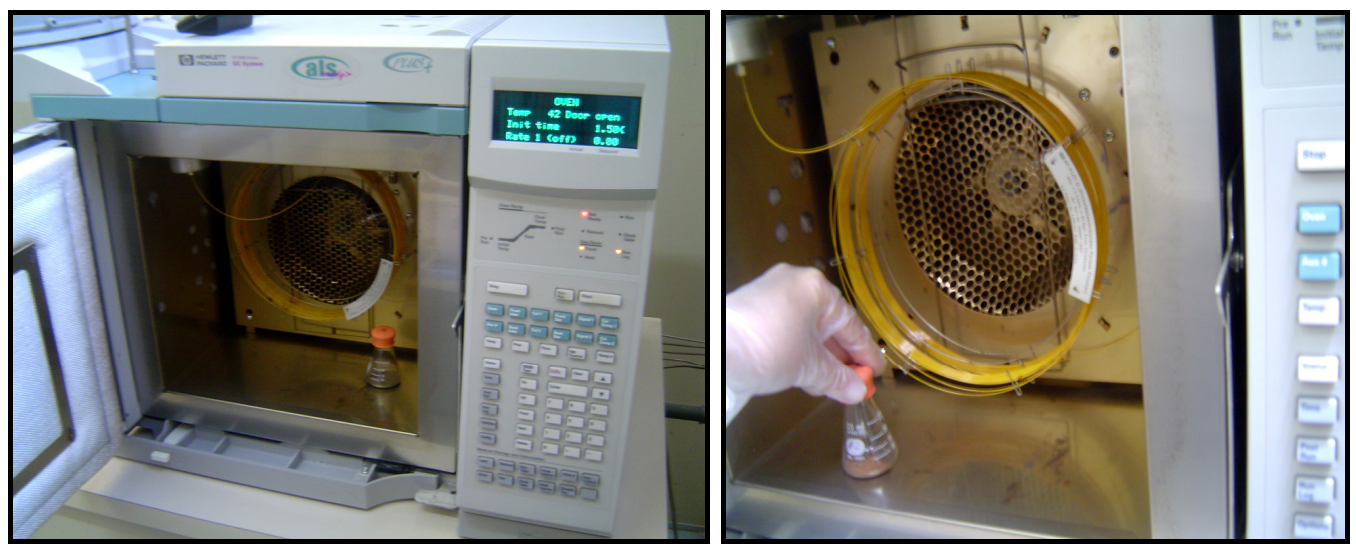

FIGURA 10 - Aquecimento da amostra utilizando o forno do CG/MS
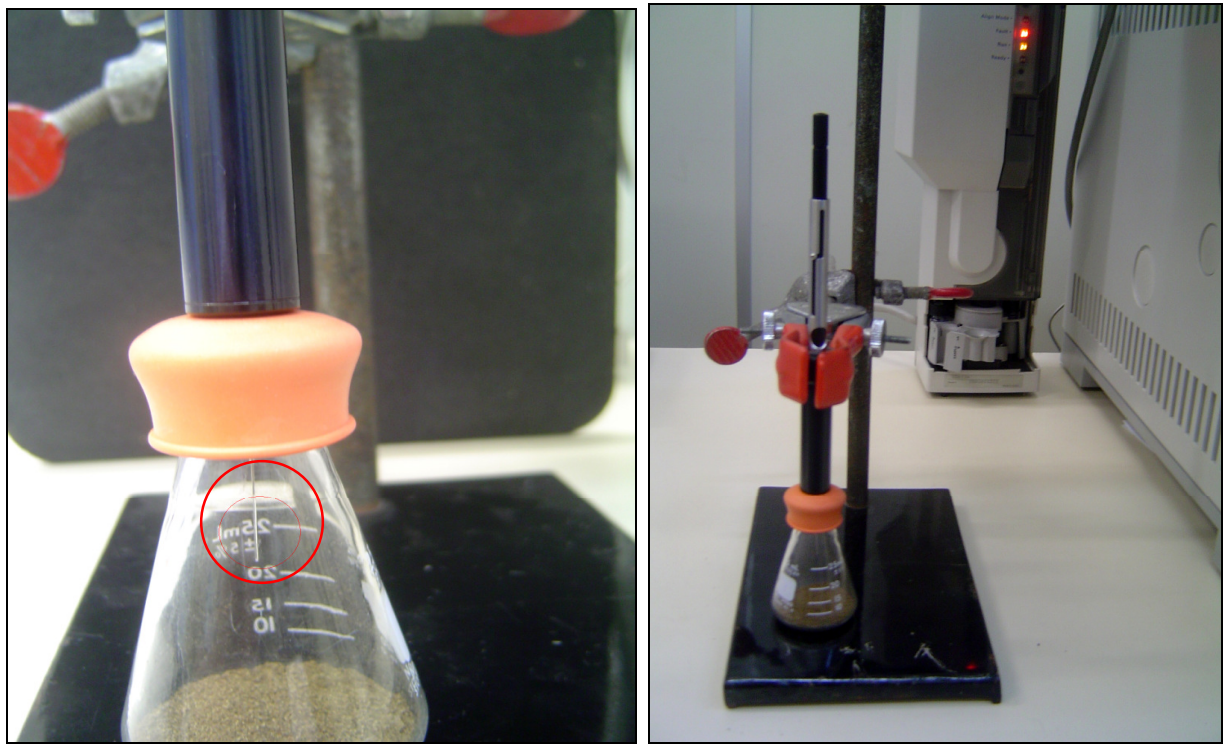

FIGURA 11 - Exposição da fibra aos voláteis emitidos após aquecimento da amostra 

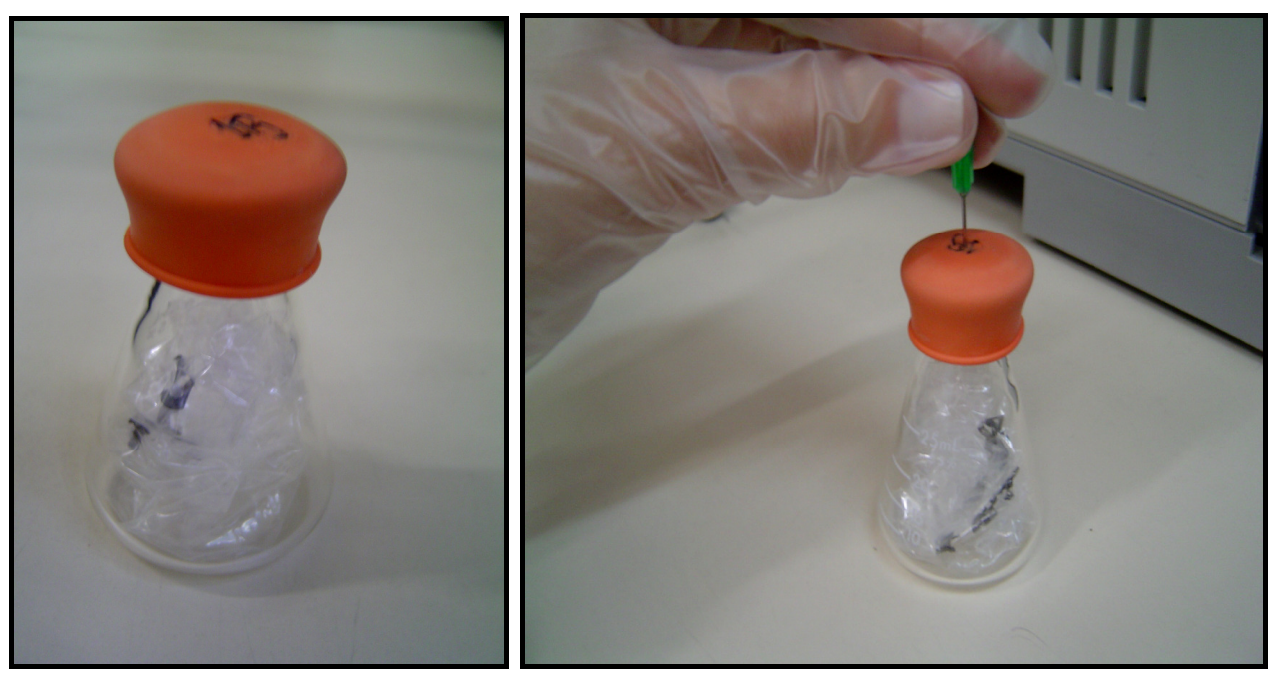

FIGURA 12 - Perfuração da vedação de borracha na análise das embalagens

\subsection{Determinação de Voláteis por Cromatografia Gasosa Acoplada a um Espectrômetro de Massa (CG-MS)}

A grande maioria dos trabalhos com óleos voláteis existentes na literatura descreve a identificação de seus constituintes pela técnica de cromatografia gasosa acoplada a espectometria de massa e/ou associada ao cálculo do índice de Kovatz. O uso desta técnica requer bancos de dados que contenham os valores dos tempos de retenção e/ou os espectros de massas para serem confrontados com os dados experimentais obtidos (Brochini, 1998).

Foi utilizado nessas análises o cromatógrafo Hewlett-Packard modelo 6890 acoplado a um detector seletivo de massas da mesma empresa modelo 5973. A coluna cromatográfica empregada foi a HP5MS (tamanho $30 \mathrm{mts}, 0,25 \mu$ de espessura do filme). Teve tempo de corrida de 35 minutos a uma temperatura crescente partindo de $50^{\circ} \mathrm{C}$, aumentando a taxa de $5^{\circ} \mathrm{C}$ por minuto, atingindo a temperatura de $280^{\circ} \mathrm{C}$. As análises foram feitas no Departamento de Alimentos e Nutrição Experimental - FCF/USP. 


\subsection{Análise Estatística - Análise de Componentes Principais (ACP)}

Para a análise dos dados e da identificação das possíveis mudanças provocadas no odor das especiarias irradiadas foi empregada a análise de componentes principais (ACP), neste caso, o software WinDas para realizar tais análises.

A Análise de Componentes Principais (ACP) é um dos métodos estatísticos mais usados quando se pretendem analisar dados multivariados e para descorrelação de dados (Rodrigues et al., 2006). Ela permite transformar um conjunto de variáveis originais, intercorrelacionadas, num novo conjunto de variáveis não correlacionadas, as componentes principais.

O objetivo mais imediato da ACP é verificar se existe um pequeno número das primeiras componentes principais que seja responsável por explicar uma proporção elevada da variação total associada ao conjunto original (Rodrigues et al., 2006).

O objetivo da análise em componentes principais é encontrar uma transformação mais representativa e geralmente mais compacta das observações. O método de ACP transforma um vetor aleatório $\mathrm{X}$ em outro vetor $\mathrm{y}($ para $\mathrm{n} \leq \mathrm{m})$ projetando $\mathrm{x}$ nas $\mathrm{n}$ direções ortogonais de maior variância - as componentes principais. Estas componentes são individualmente responsáveis pela variância das observações, e neste sentido, representam-nas mais claramente. Geralmente grande parte da variância dos dados é explicada por um número reduzido de componentes, sendo possível descartar as restantes sem grande perda de informação (Rodrigues et al., 2006).

De fato, é possível demonstrar que o método de ACP é uma técnica ótima de redução linear de dimensão, relativa ao erro quadrático médio. Tal redução é 
vantajosa para compressão, visualização dos dados, redução do cálculo necessário em fases de processamento posterior.

A técnica das componentes principais é relativamente simples. Basta utilizar a informação contida na matriz de covariância dos dados.(Rodrigues et al., 2006).

Os conceitos da ACP lidam com matrizes de covariância de vetores aleatórios e com a decomposição em valores e vetores próprios destas matrizes. 


\section{RESULTADOS E DISCUSSÃO}

\subsection{Cinnamomum Zeylanicum BLUME - (Canela)}

Foram identificados os compostos majoritários das amostras controle (0kGy) de canela pela técnica de cromatografia gasosa acoplada ao espectrômetro de massa (CG/MS). Na Tabela 7 são apresentados tais compostos. Para cada composto identificado foi apresentado o índice qualificador, que é a comparação de tais quimiotipos à biblioteca NIST98L, dando o nome do composto. Portanto, quanto maior o índice qualificador, maior a semelhança do composto ao quimiotipo dado pela biblioteca do CG/MS.

TABELA 7 - Compostos majoritários presentes nas amostras controle (0 kGy) de canela.

\begin{tabular}{lclc}
\hline \multicolumn{1}{c}{ Composto } & Qual & \multicolumn{1}{c}{ Composto } & Qual \\
\hline Benzaldeído & 76 & (+)-Sativeno & 89 \\
Eucaliptol & 98 & Alfa-Bergamoteno & 97 \\
Beta-Linalool & 83 & Cariofileno & 94 \\
Benzenepropanal & 89 & (Z,E)-alpha-Farneseno & 93 \\
Borneol & 83 & Alpha-Guaieno & 91 \\
4-Terpineol & 97 & Beta-Patchouleno & 86 \\
(+)-.alpha.-Terpineol & 91 & Epsilon-Muuroleno & 99 \\
Cinamaldeído, (E)- & 96 & Alfa-Guaieno & 98 \\
Cumaldeído & 97 & Alfa-Amorfeno & 99 \\
Acetato de Borneol & 91 & Beta-Bisaboleno & 93 \\
(+)-4-Careno & 95 & Epsilon-Cadineno & 98 \\
Alpha.-Cubebeno & 98 & (-)-Calameneno & 95 \\
(+)-Ciclosativeno & 97 & Napfalina, 1,2,3,4,6,8a-hexahydro-1- & 98 \\
Copaeno & 99 & isopropyl-4,7-dimethyl- & 72 \\
Cedreno & 90 & Cadalene & 95 \\
Beta-Elemeno, (-)- & 99 & 2-Metil-1H-imidazo(1,2-a)pirrolo(3,2- & 83 \\
\hline
\end{tabular}

${ }^{*}$ Qual: valor qualificador do composto identificado em relação à biblioteca NIST98.L. 
Trabalhos prévios sobre o óleo de C. Zeylanicum BLUME indicaram uma grande diversidade da composição química. Thomas e colaboradores em 1987 identificaram a presença de eugenol. Senanayake em 1978, identificou a presença de (E)-cinamaldeído cânfora. Rao e colaboradores em 1988 identificaram a presença de benzoato de metila.

A presença de linalol, (E)- cinamaldeído também foram identificados por Jirovetz et al. em 2001, quando analisava óleos essenciais presentes na canela. Lima e colaboradores em 2005, analisando óleos essenciais das folhas e galhos da canela (Cinnamomum Zeylanicum BLUME) identificaram a presença de benzaldeído, borneol, terpineol, (E-) Cinamaldeído, beta-cariofileno e copaeno, sendo que, predominou-se a presença de cariofileno, óxido de cariofileno e (E-) cinamaldeído nos galhos.

Os maiores picos cromatográficos encontrados na amostra controle de canela (C. Zeylanicum BLUME) podem ser observados na TABELA 8.

TABELA 8. Quantificação dos compostos voláteis das amostras controle (0kGy), das amostras de dose intermediária de 10kGy e das amostras de dose final de $25 k G y$.

\begin{tabular}{|c|c|c|c|c|c|c|}
\hline Canela & \multicolumn{3}{|c|}{ Área } & \multicolumn{3}{c|}{ Valor Percentual } \\
\hline & OkGy & 10kGy & 25kGy & OkGy & 10kGy & 25kGy \\
\hline Bornyl acetate & 33829599 & 14815987 & 6558233 & 100 & 43,80 & 19,39 \\
\hline $\begin{array}{c}\text { Copaene } \\
\text { alpha- }\end{array}$ & 84478339 & 30705833 & 6203915 & 100 & 36,35 & 7,34 \\
Bergamotene & 13688072 & 5095606 & 1016238 & 100 & 37,23 & 7,42 \\
\hline Caryophyllene & 44663952 & 22598063 & 4098035 & 100 & 50,60 & 9,18 \\
\hline Calamenene & 20178877 & 10022709 & 1906748 & 100 & 49,67 & 9,45 \\
\hline
\end{tabular}




\section{- Amostras irradiadas com 5kGy}

Nas Figuras 13 e 14, são mostrados os perfis cromatográficos da canela irradiada com a dose de 5kGy. Os perfis mostraram alguns picos menores quando comparado com o perfil cromatográfico da amostra controle (OkGy), obtendo a média de $47,18 \%$ de perda de compostos.

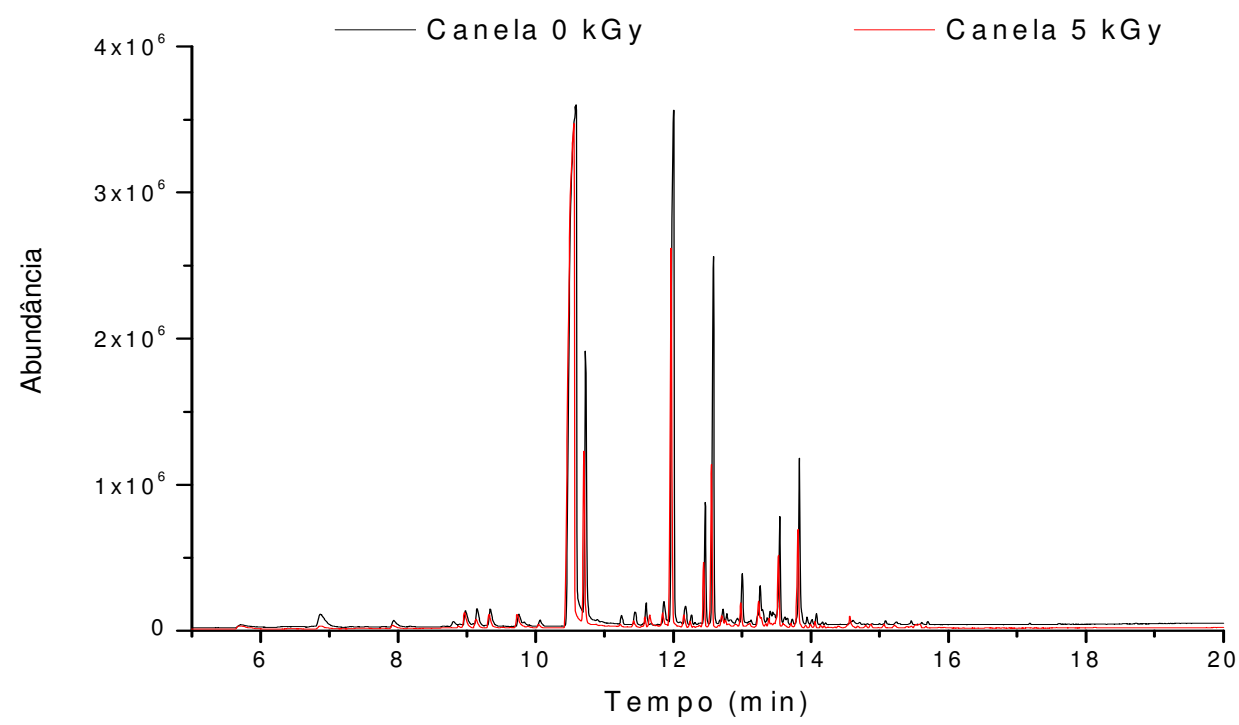

FIGURA 13. Perfis cromatográficos totais da análise das amostras de canela irradiada com a dose de 5kGy sobreposta à uma amostra controle (0kGy) de canela. 


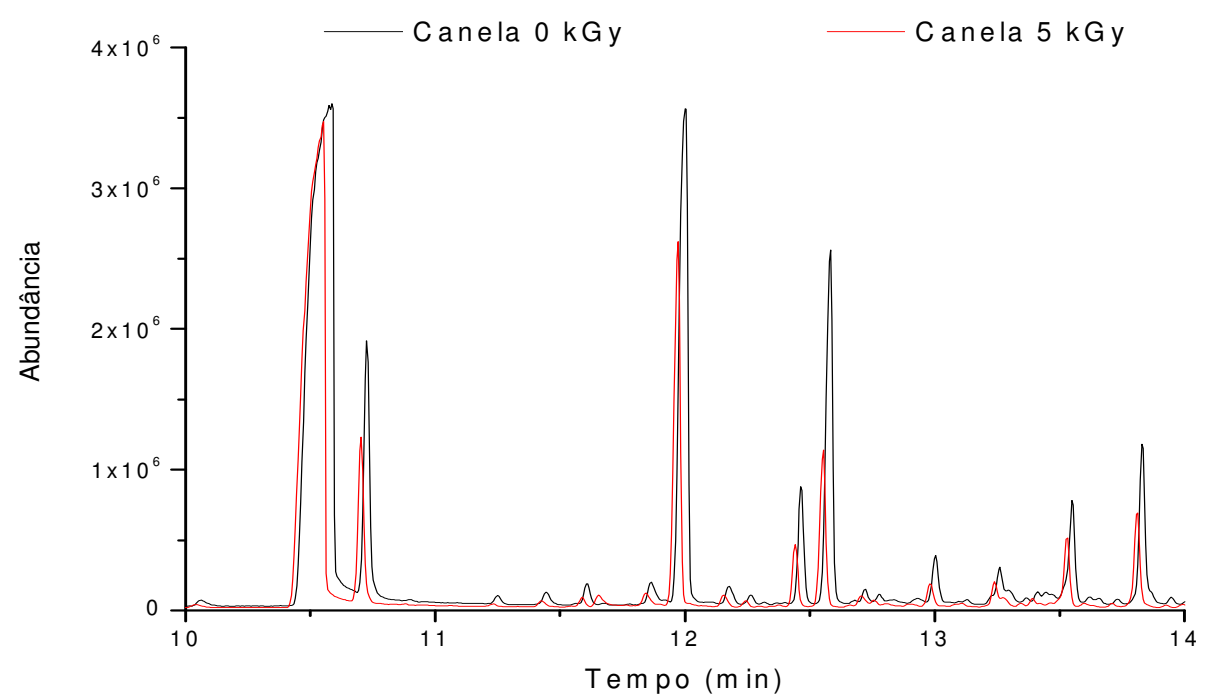

FIGURA 14. Perfis cromatográficos parciais da análise da amostra de canela irradiada com a dose de 5kGy sobreposta à uma amostra controle (0kGy) de canela.

\section{- Amostras irradiadas com 10kGy}

Os perfis cromatográficos totais e parciais da canela irradiada com a dose de 10kGy mostraram alguns picos menores quando comparado com o perfil cromatográfico das amostras controle (FIGURAS 15 e 16) e com o perfil das amostras irradiadas com 5kGy (FIGURAS 13 e 14). O acetato de borneol apresentou uma diminuição de $56,2 \%$, o copaeno de $63,65 \%$, o alfabergamoteno de $62,77 \%$, cariofileno de $49,4 \%$ e o calameneno de $50,33 \%$, obtendo perda média de $56,47 \%$ de compostos, como pode ser observado na TABELA 8. 


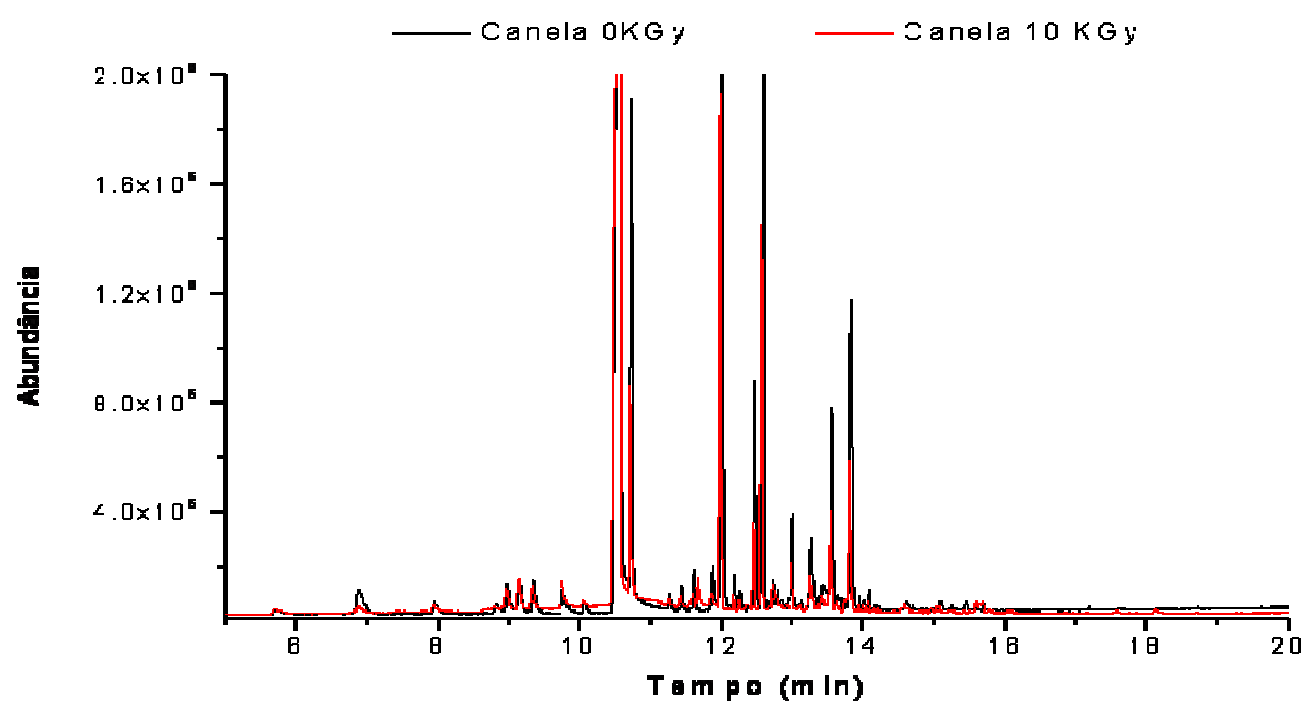

FIGURA 15. Perfis cromatográficos totais da análise da amostra de canela irradiada com a dose de 10kGy sobreposta à uma amostra controle (0kGy) de canela.

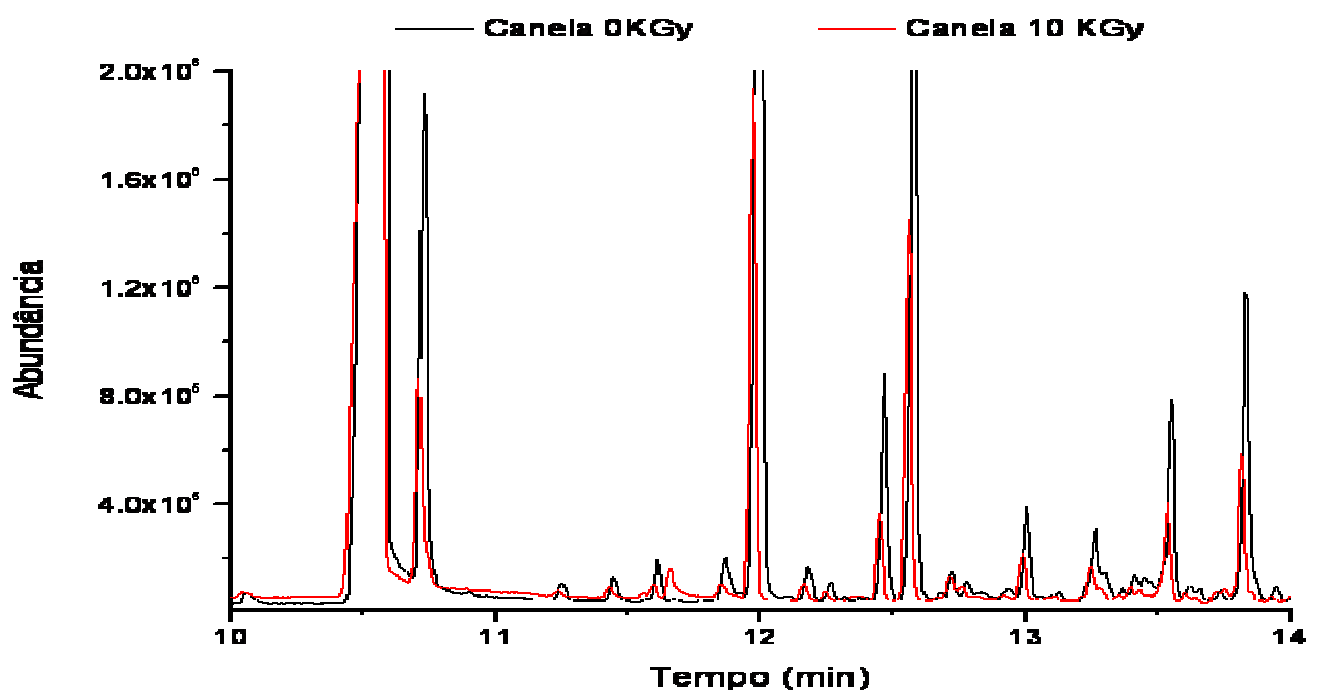

FIGURA 16. Perfis cromatográficos parciais da análise de uma amostra de canela irradiada com 10kGy sobreposta à uma amostra controle (0kGy) de canela 


\section{- Amostras irradiadas com 15kGy}

Analisando a diferença dos perfis cromatográficos totais e parciais entre as amostras irradiadas com 15kGy e as amostras controle (FIGURA 17 e 18), é nítida a diminuição dos picos cromatográficos das amostras de $15 \mathrm{kGy}$, em que os compostos majoritários sofreram uma queda significativa quando comparado a amostra controle e de 5 kGy. Em relação a dose de 10 kGy, a diferença é menor. Houve perda em média de $88,97 \%$ de compostos.

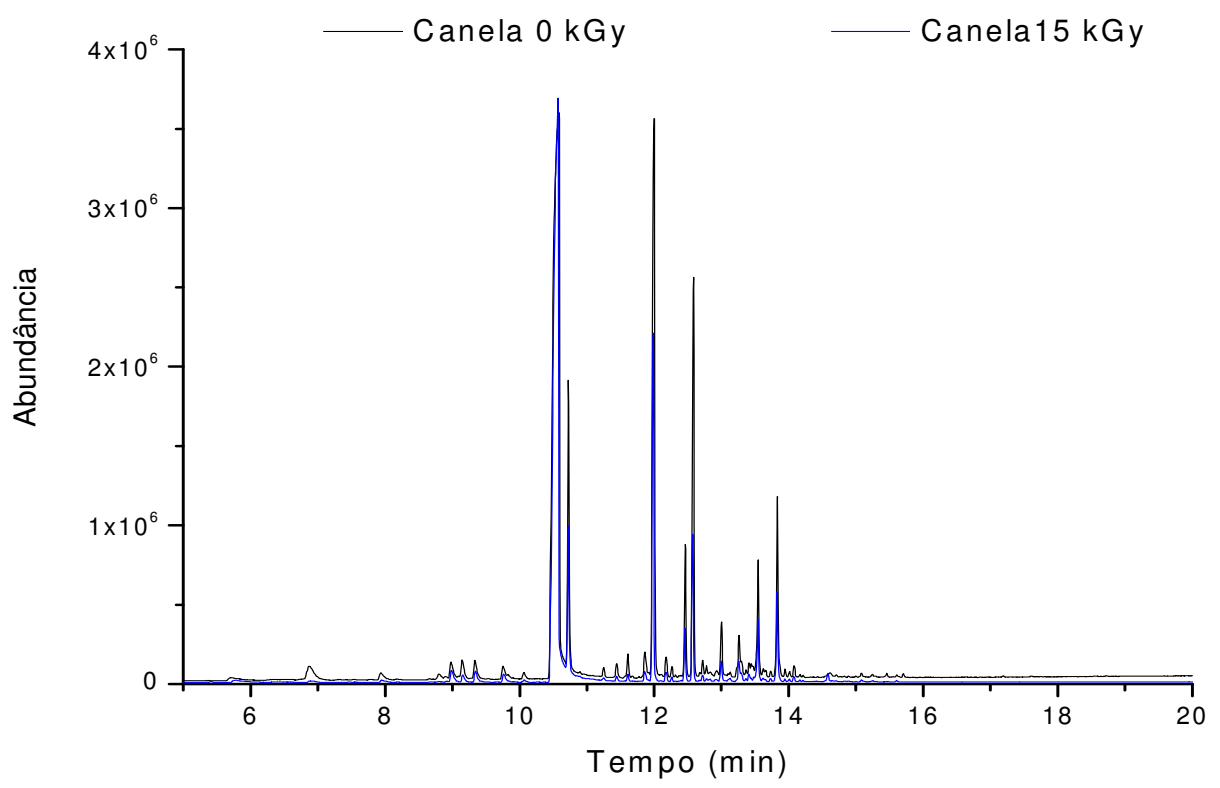

FIGURA 17. Perfis cromatográficos totais da análise de uma amostra de canela irradiada com 15kGy sobreposta à uma amostra controle (0kGy) de canela. 


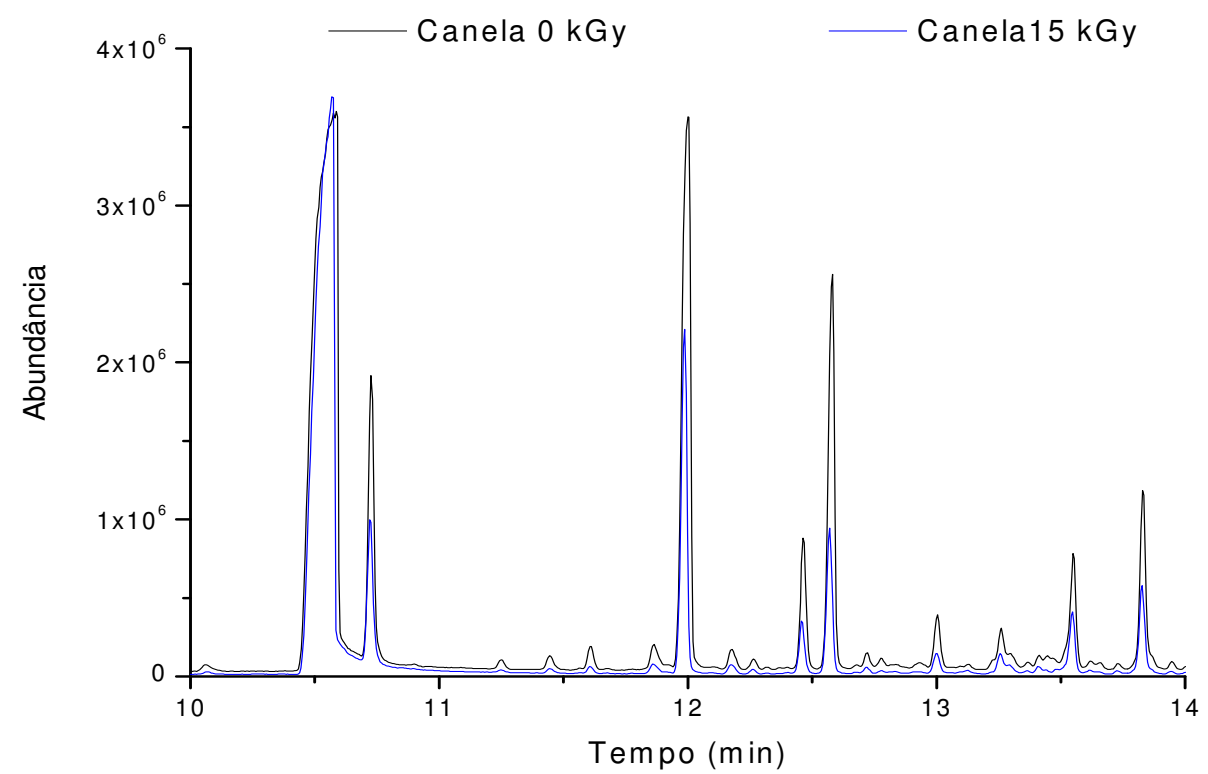

FIGURA 18. Perfis cromatográficos parciais da análise de uma amostra de canela irradiada com 15kGy sobreposta à uma amostra controle (OkGy) de canela.

\section{- Amostras irradiadas com 20kGy}

Analisando a diferença dos perfis cromatográficos totais e parciais entre a amostra irradiada com 20kGy e a amostra controle (FIGURAS 19 e 20) é nítida a diminuição dos picos cromatográficos das amostras de 20kGy, onde os compostos majoritários sofreram uma queda significativa, com perda média de aproximadamente $85,4 \%$. 


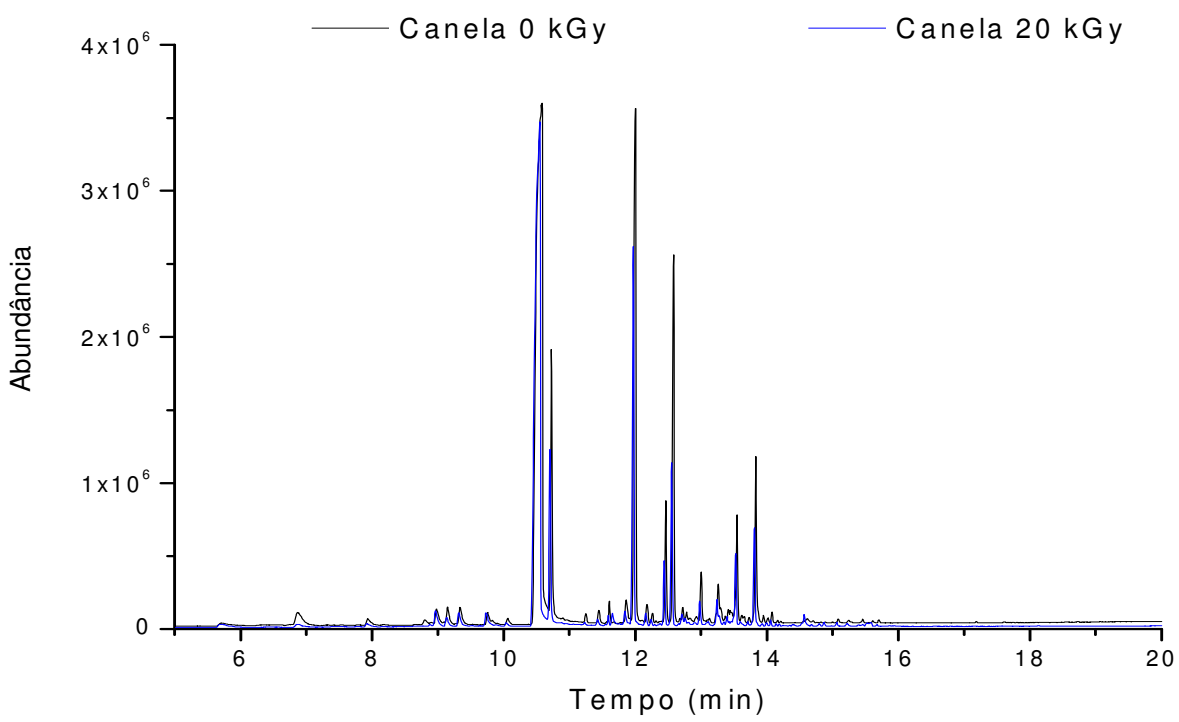

FIGURA 19. Perfis cromatográficos totais da análise de uma amostra de canela irradiada com 20kGy sobreposta à uma amostra controle (OkGy) de canela.

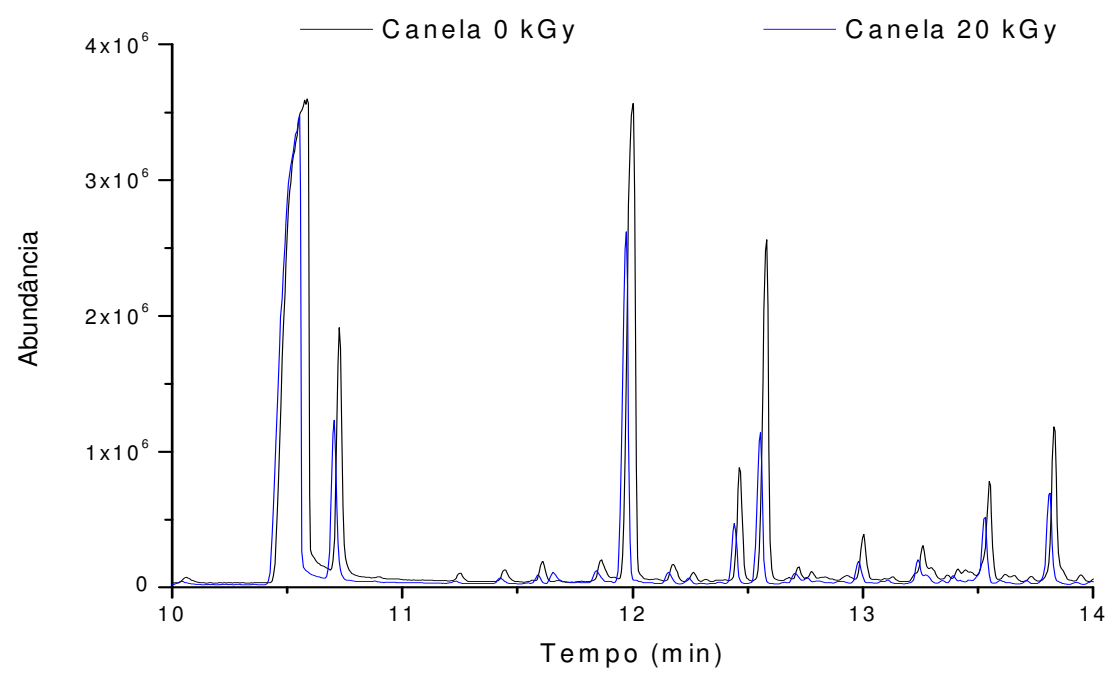

FIGURA 20. Perfis cromatográficos parciais da análise de uma amostra de canela irradiada com 20kGy sobreposta à uma amostra controle (0kGy) de canela. 


\section{- Amostras irradiadas com 25kGy}

Analisando a diferença dos perfis cromatográficos totais e parciais entre a amostra irradiada com 25kGy e a amostra controle (FIGURAS 21 e 22), é nítida a diminuição dos picos cromatográficos das amostras de 25kGy, onde os compostos majoritários sofreram uma queda significativa, pode-se observar na Tabela 8 que o acetato de borneol apresentou uma diminuição de 80,61\%, o copaeno de 92,66\%, alfa-bergamoteno de 92,58\%, cariofileno de 90,82\% e calameneno de 90,55 ; com a média atingindo $89,44 \%$ de perda de compostos.

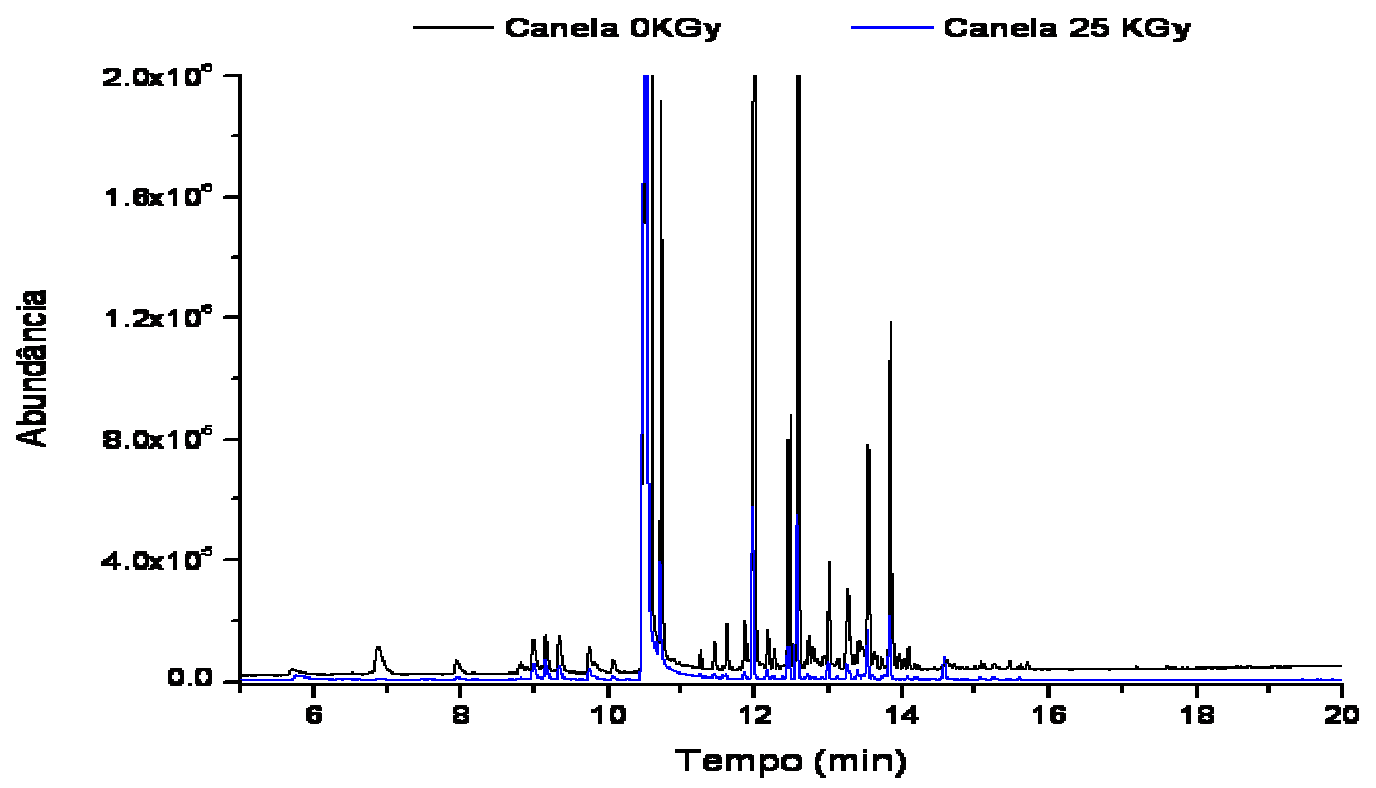

FIGURA 21. Perfis cromatográficos totais da análise da amostra de canela irradiada com a dose de 25kGy sobreposta à uma amostra controle (0kGy) de canela. 


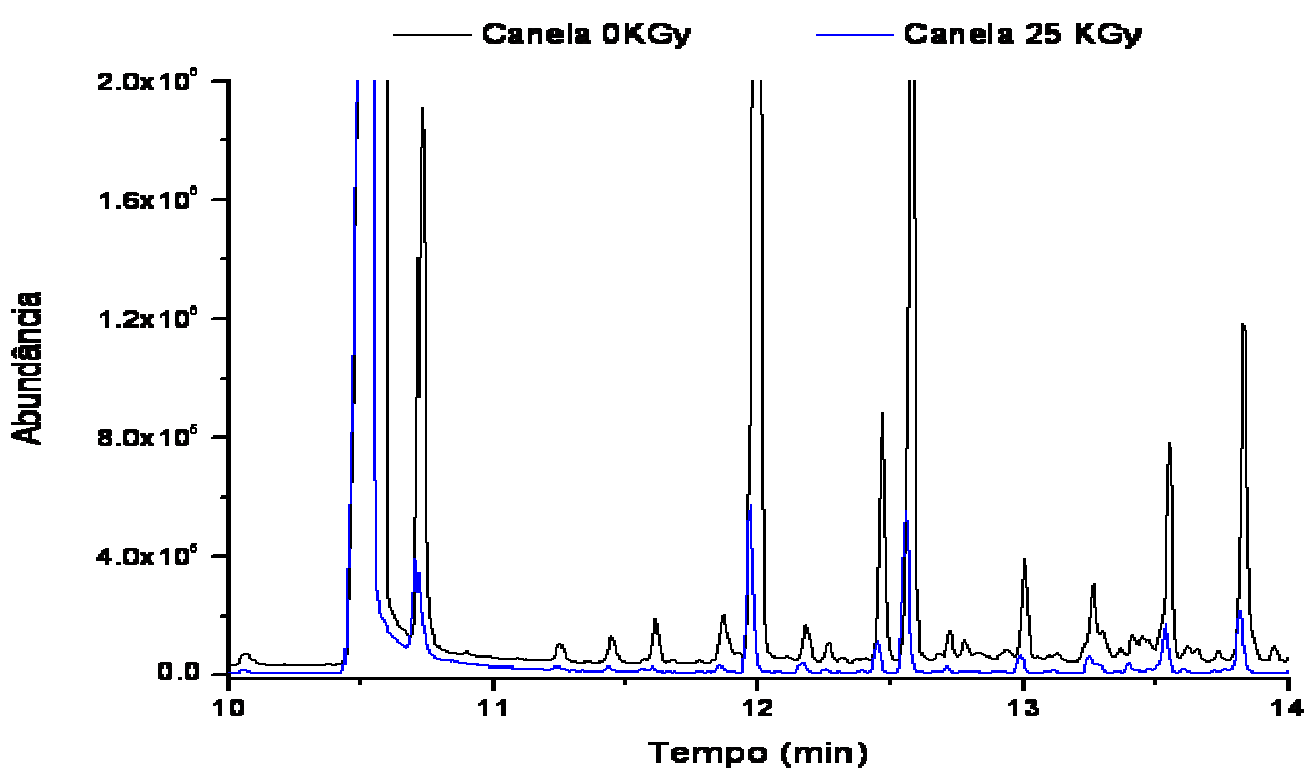

FIGURA 22. Perfis cromatográficos parciais da análise da amostra de canela irradiada com 25kGy sobreposta à amostra controle (0kGy) de canela.

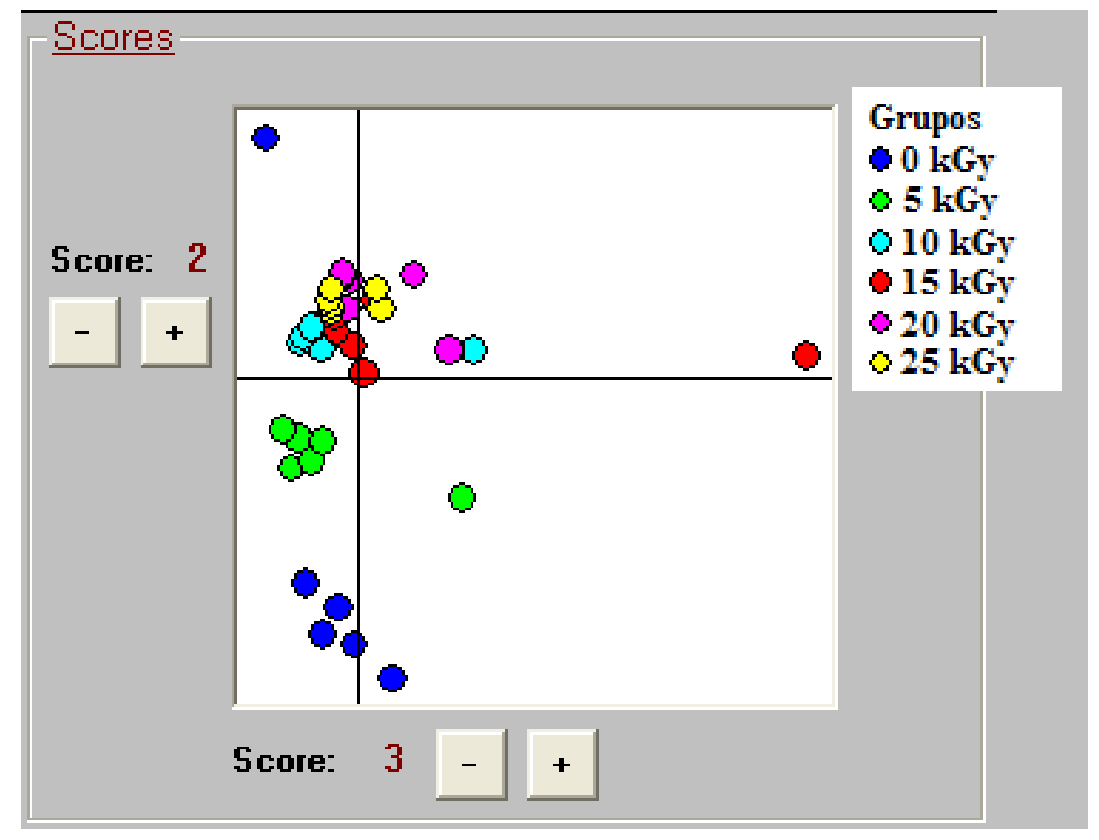

FIGURA 23 - Análise de Variáveis Canônicas da Canela 
Pode-se observar que na análise de variáveis canônicas feita pelo software estatístico WinDas existe uma grande diferença entre as amostras controle (0kGy) em relação as amostras irradiadas com 15, 20 e 25kGy e uma diferença um pouco menor das amostras de 5kGy e 10kGy. Em contrapartida, as amostras irradiadas com 15, 20 e 25kGy não demonstraram significativa diferença entre si.

No caso da canela, a irradiação com 5kGy obteve porcentagem de perda menor que as amostras de 10kGy não ultrapassando $50 \%$ quando comparado às amostras controle. A dose de 10kGy acarretou em perdas de aproximadamente $56 \%$ dos compostos voláteis. As doses de 15 e 20 kGy obtiveram perda maior de compostos em relação as doses anteriores de 5 e 10kGy. Já a irradiação com a dose de 25kGy obteve média de 89,44\% de perda de compostos.

\subsection{Myristica Fragans - (Noz - moscada)}

Foram detectados os compostos nas amostras controle (OkGy) de noz moscada utilizando o índice qualificador do composto detectado em relação à biblioteca NIST98. Na Tabela 9 são apresentados os compostos detectados e a presença de muitos deles foi relatada por Fraipe em 2002, classificando a composição química dos óleos essenciais de noz moscada como a elemicina, miristicina (composto que atua como narcótico e é extremamente tóxico se ingerido em grandes quantidades), terpineol, confeno, borneol, esclareol, pineno, elemenicina, copeno, linalol, eugenol, ligananos, oléos fixos e niacina. 
TABELA 9. Compostos presentes nas amostras controle de noz-moscada (nãoirradiada)

\begin{tabular}{lclc}
\hline Composto & Qual & Composto & Qual \\
\hline 1R-.alpha.-Pinene & 93 & Alpha-Terpinene & 95 \\
Beta.-Pinene & 94 & cis-2,6-Dimethyl-2,6-octadiene & 90 \\
Alpha.-Phellandrene & 90 & Neryl propionate & 72 \\
Alpha-Terpinene & 97 & Alpha-Muurolene & 89 \\
Apsilon-Terpinene & 96 & Copaene & 99 \\
Terpineol, Z-.beta.- & 96 & (-)-beta-Elemene & 92 \\
(+)-4-Carene & 98 & Eugenol methyl ether & 95 \\
Terpineol, Z-.beta.- & 96 & Bicyclo[7.2.0]undec-4-ene, & 99 \\
Fenchol & 91 & Al11,11-trimethyl-8-methylene- & 97 \\
4-Isopropyl-1-methyl-2- & 98 & Allo-Aromadendrene & 98 \\
cyclohexen-1-ol & 86 & Alpha-Farnesene & 95 \\
1-Terpinenol & 97 & Alpha.-Caryophyllene & 97 \\
4-Isopropyl-1-methyl-2- & 72 & Germacrene D & 95 \\
cyclohexen-1-ol & 90 & Epsilon-Muurolene & 99 \\
Camphene hydrate & 95 & Germacrene D & 97 \\
Borneol & 94 & Isoeugenol methyl ether & 95 \\
4-Terpineol & 96 & Beta-Gurjunene & 96 \\
Alpha-Terpineol & 76 & Beta-Bisabolene & 98 \\
Trans-Piperitol & 98 & Myristicin & 98 \\
Cyclofenchene & & Naphthalene, 1,2,3,4,6,8a- & \\
Cumaldehyde & 87 & hexahydro-1-isopropyl-4,7- & 97 \\
& & dimethyl & \\
Bergamiol & 96 & (+)-Camphene & 78 \\
& 81 & Elemicin & 95 \\
Izosafrol & 78 & Isoelemicin & 94 \\
Tricyclene & 81 & & \\
Ascaridiol & 1R-.alpha.-Pinene & &
\end{tabular}

${ }^{*}$ Qual: valor qualificador do composto identificado em relação à biblioteca NIST98.L

\section{- Amostras irradiadas com 5 kGy}

Ao contrário do que se esperava, após a irradiação das amostras de nozmoscada houve um aumento progressivo dos compostos voláteis, quanto maior 
a dose empregada, picos cromatográficos maiores foram observados (FIGURAS 24 a 32).

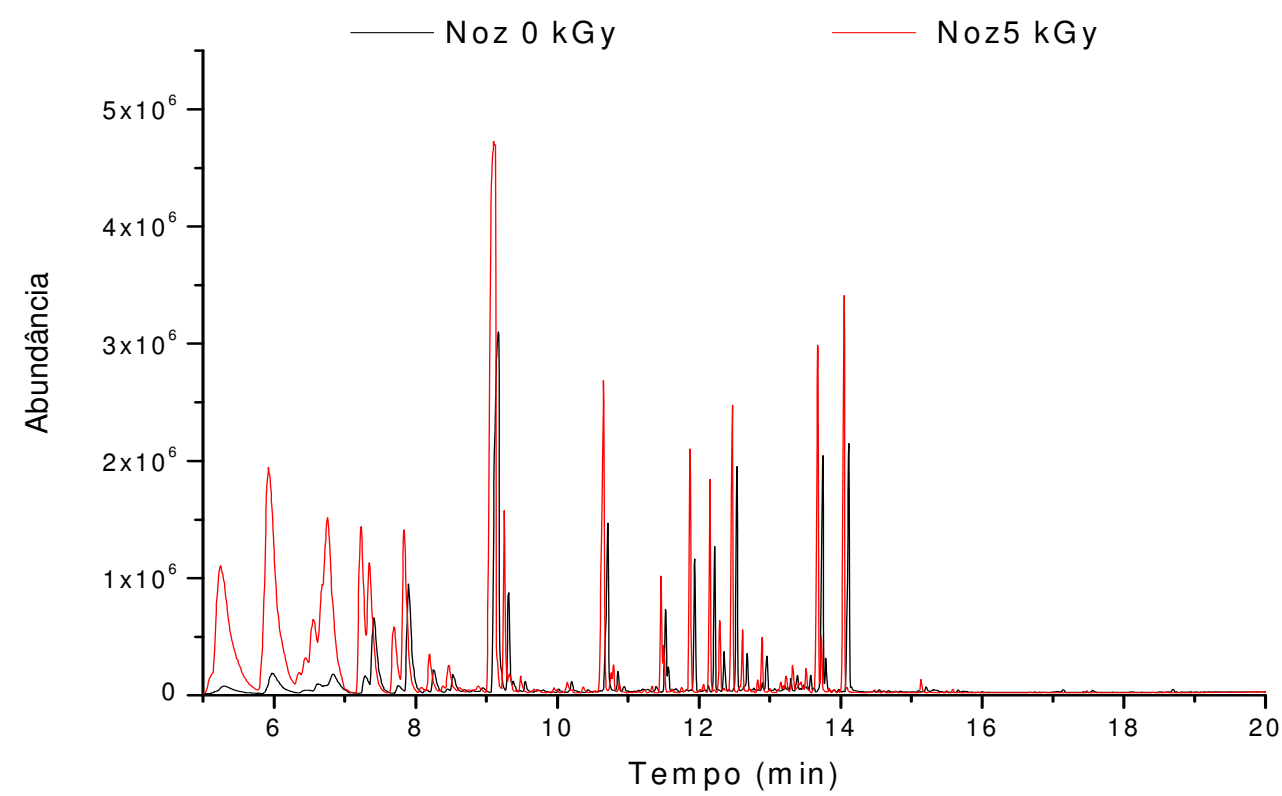

FIGURA 24. Perfis cromatográficos totais da análise das amostras de nozmoscada irradiada com 5kGy sobreposta à amostra controle (0kGy) de nozmoscada. 


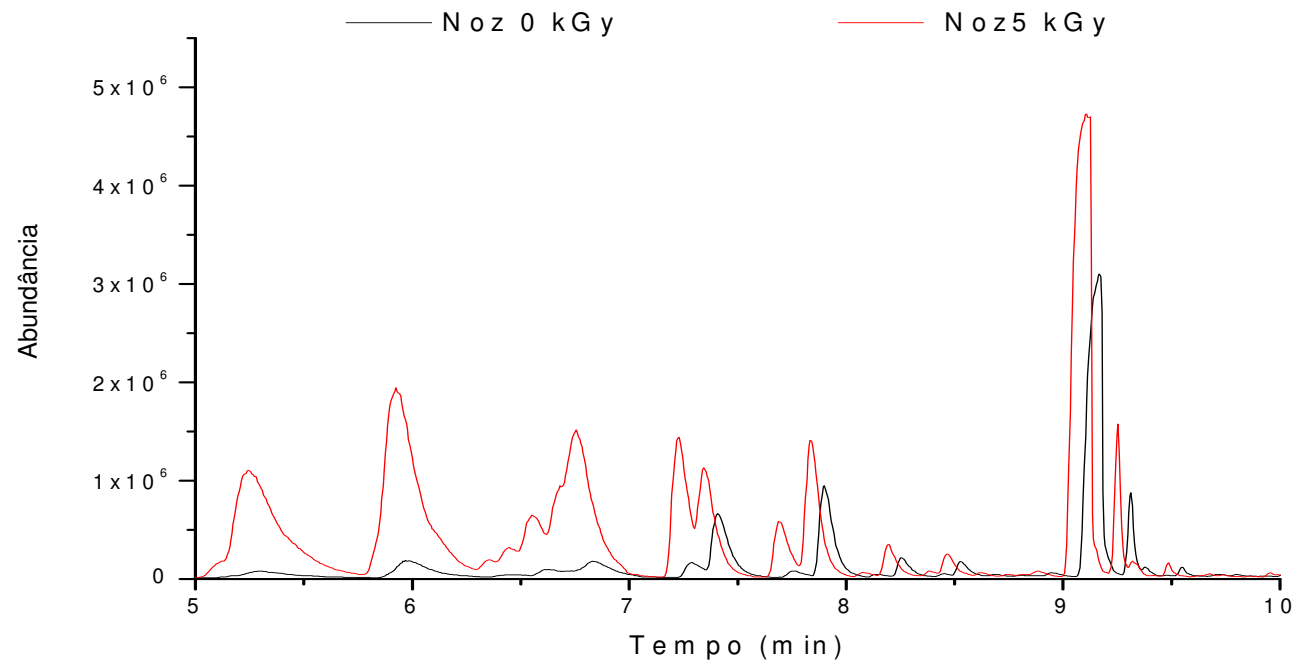

FIGURA 25. Perfis cromatográficos parciais da análise das amostras de nozmoscada irradiada com 5kGy sobreposta à amostra controle (0kGy) de nozmoscada.

\section{- Amostras irradiadas com 10kGy}

A amostra de noz moscada irradiada com 10kGy apresentou um grande aumento da maioria dos picos cromatográficos como mostram as FIGURAS $26 \mathrm{e}$ 27, portanto, a quantidade dos compostos presentes na amostra controle obtiveram um aumento em média de $61 \%$ quando submetida à dose de $10 \mathrm{kGy}$ de radiação gama. Como mostra a Tabela 10, o 4-terpineol teve um decréscimo de $13,68 \%$, o alfa-terpineol um aumento de $103,46 \%$, o cariofileno aumento de $65,89 \%$, a miristicina $75,05 \%$ e a elemicina $77,65 \%$. Nas figuras 7 e 8 , a amostra irradiada com 25kGy também mostrou um aumento dos picos cromatográficos, onde o 4-terpineol aumentou $46 \%$, porcentagem menor da amostra analisada com 10kGy, o alfa-terpineol também sofreu uma perda menor com 52,65\%, o cariofileno $16,52 \%$, já a miristicina aumentou $85.7 \%$ e a elemicina aumentou $135,95 \%$. 


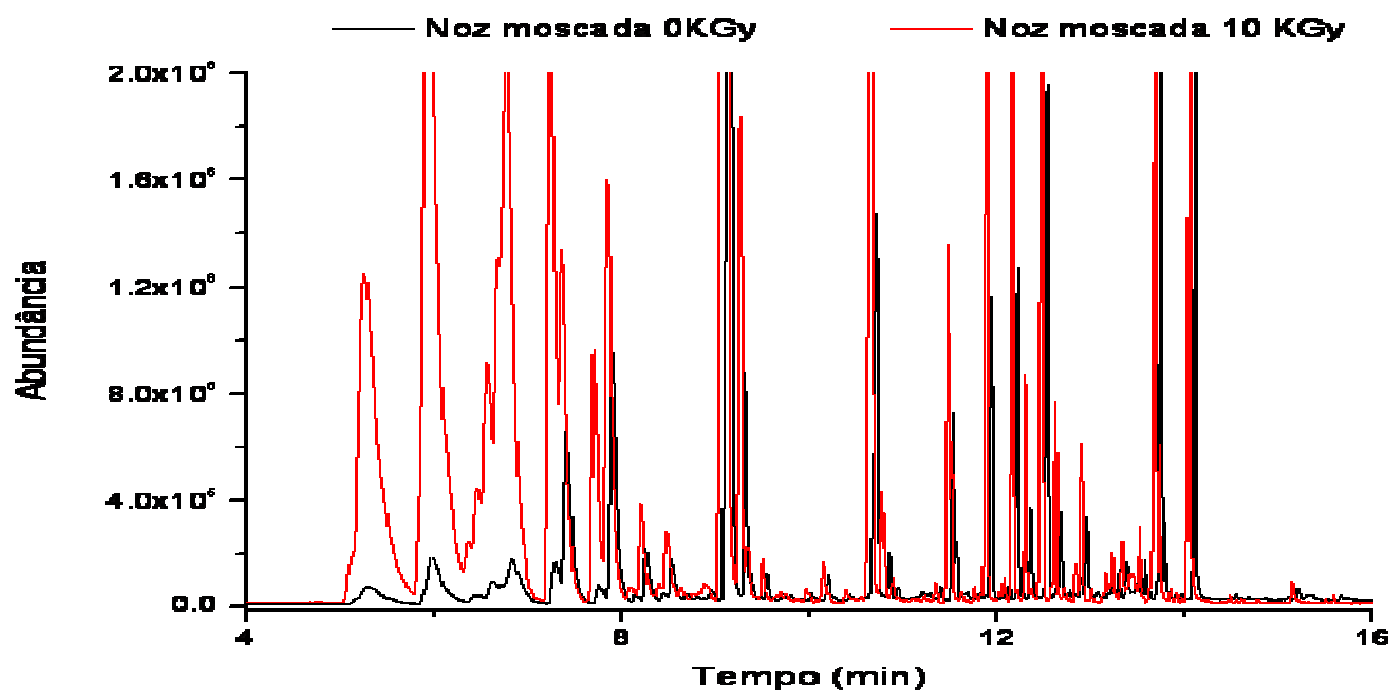

FIGURA 26. Perfis cromatográficos totais da análise da amostra de noz moscada irradiada com a dose de 10kGy sobreposta à uma amostra controle (OkGy) de noz - moscada.

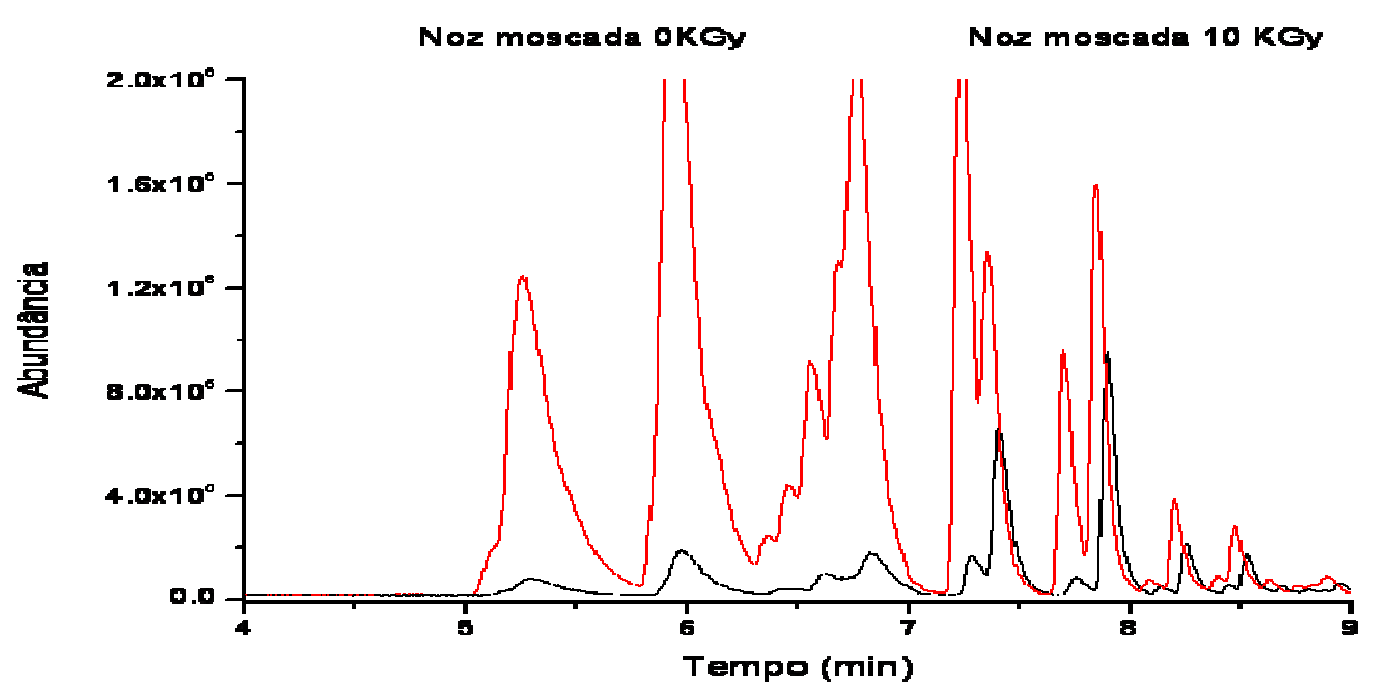

FIGURA 27. Perfis cromatográficos parciais da análise da amostra de noz moscada irradiada com 10kGy sobreposta à amostra controle (0kGy) de noz moscada 


\section{- Amostras irradiadas com 15kGy}

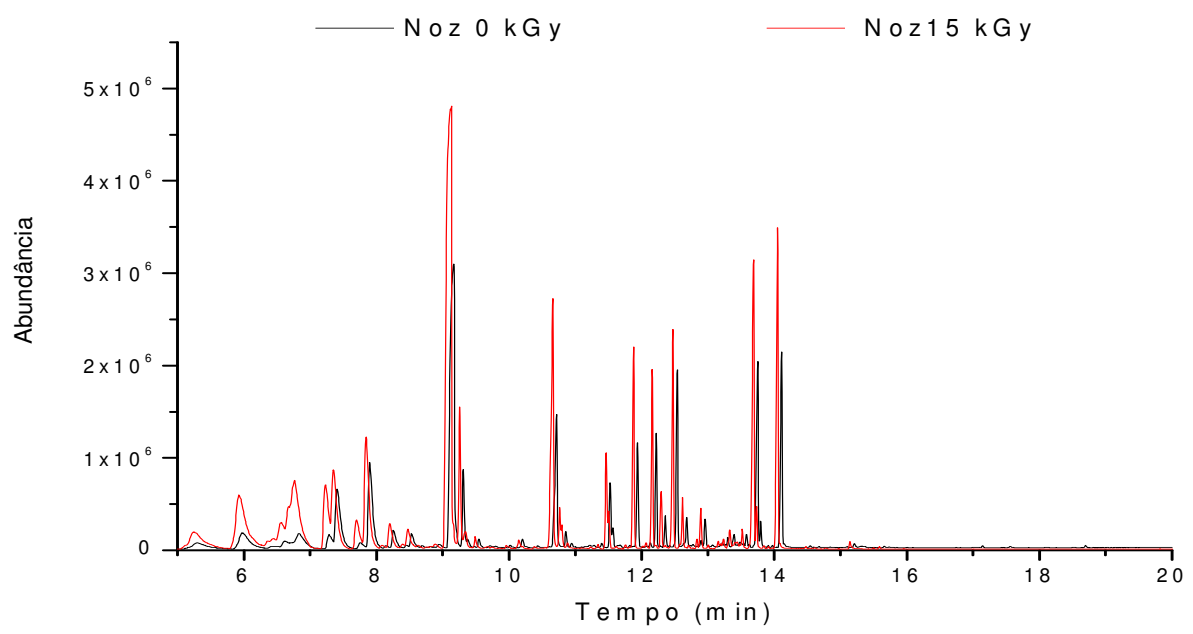

FIGURA 28. Perfis cromatográficos totais da análise da amostra de noz moscada irradiada com 15kGy sobreposta à amostra controle (0kGy) de noz moscada

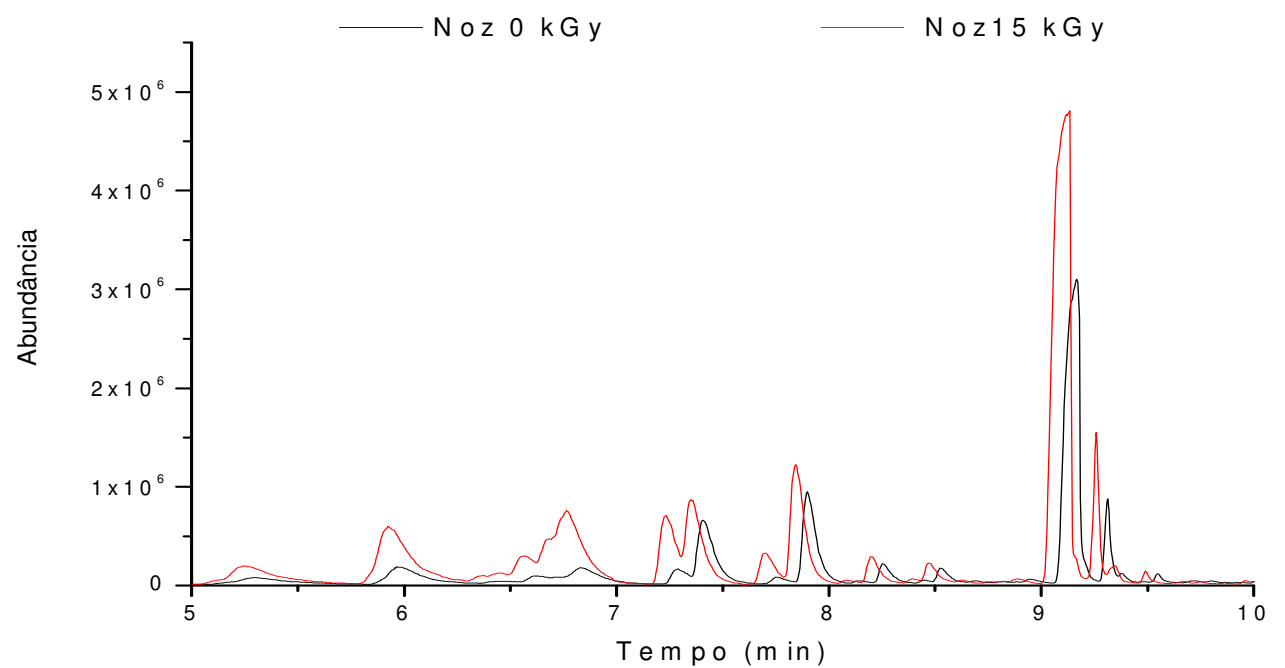

FIGURA 29. Perfis cromatográficos parciais da análise da amostra de noz moscada irradiada com 15kGy sobreposta à amostra controle (0kGy) de noz moscada 
- Amostras irradiadas com 20 kGy

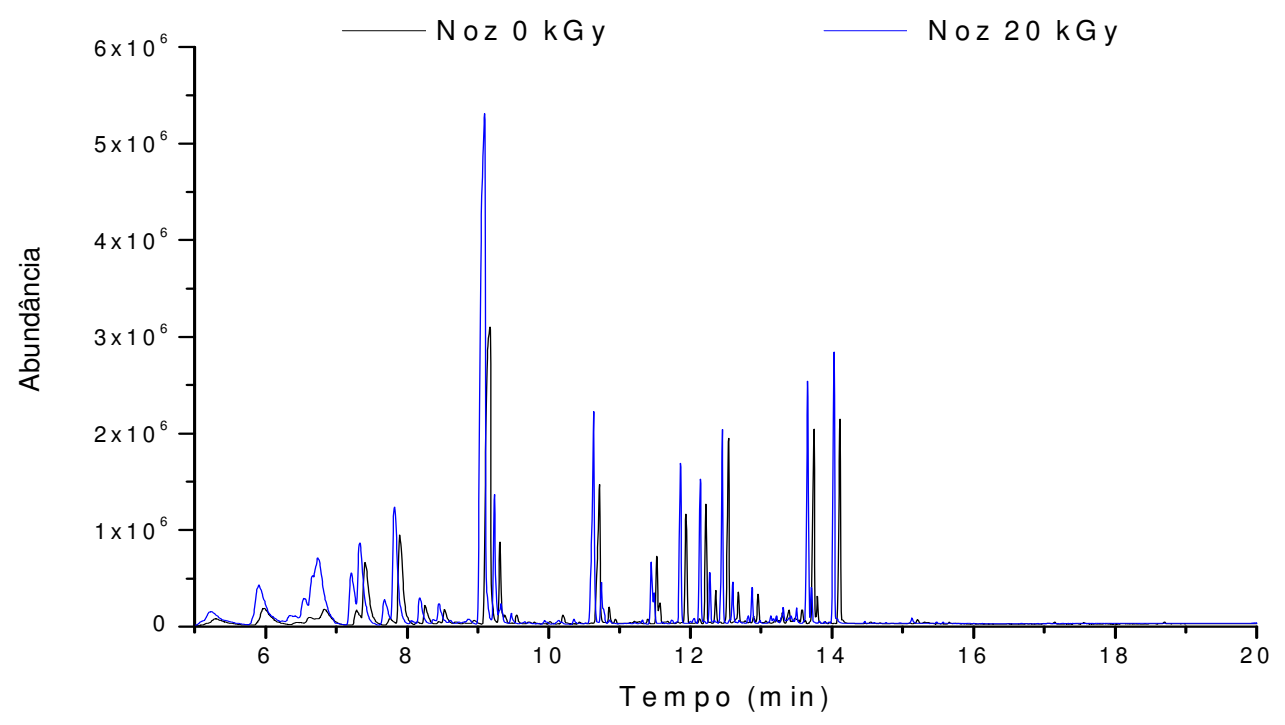

FIGURA 30. Perfis cromatográficos totais da análise da amostra de noz moscada irradiada com 20kGy sobreposta à amostra controle (0kGy) de noz moscada .

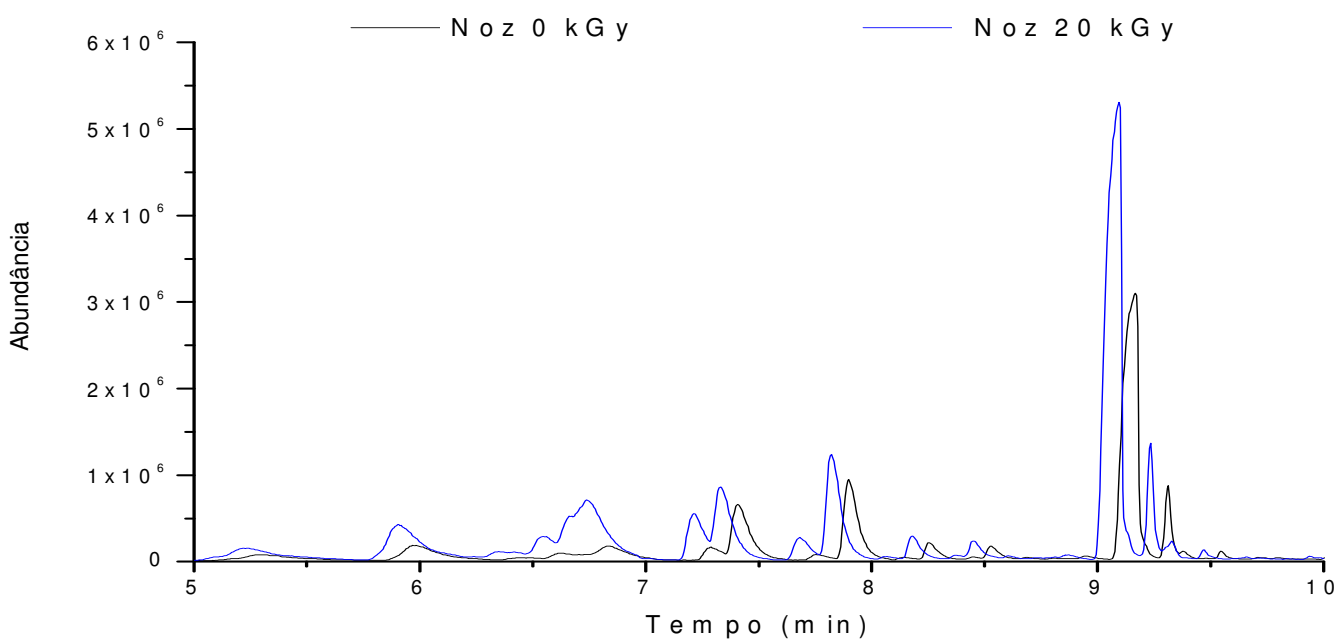

FIGURA 31. Perfis cromatográficos parciais da análise da amostra de noz moscada irradiada com 20kGy sobreposta à amostra controle (0kGy) de noz moscada 
- Amostras irradiadas com 25kGy

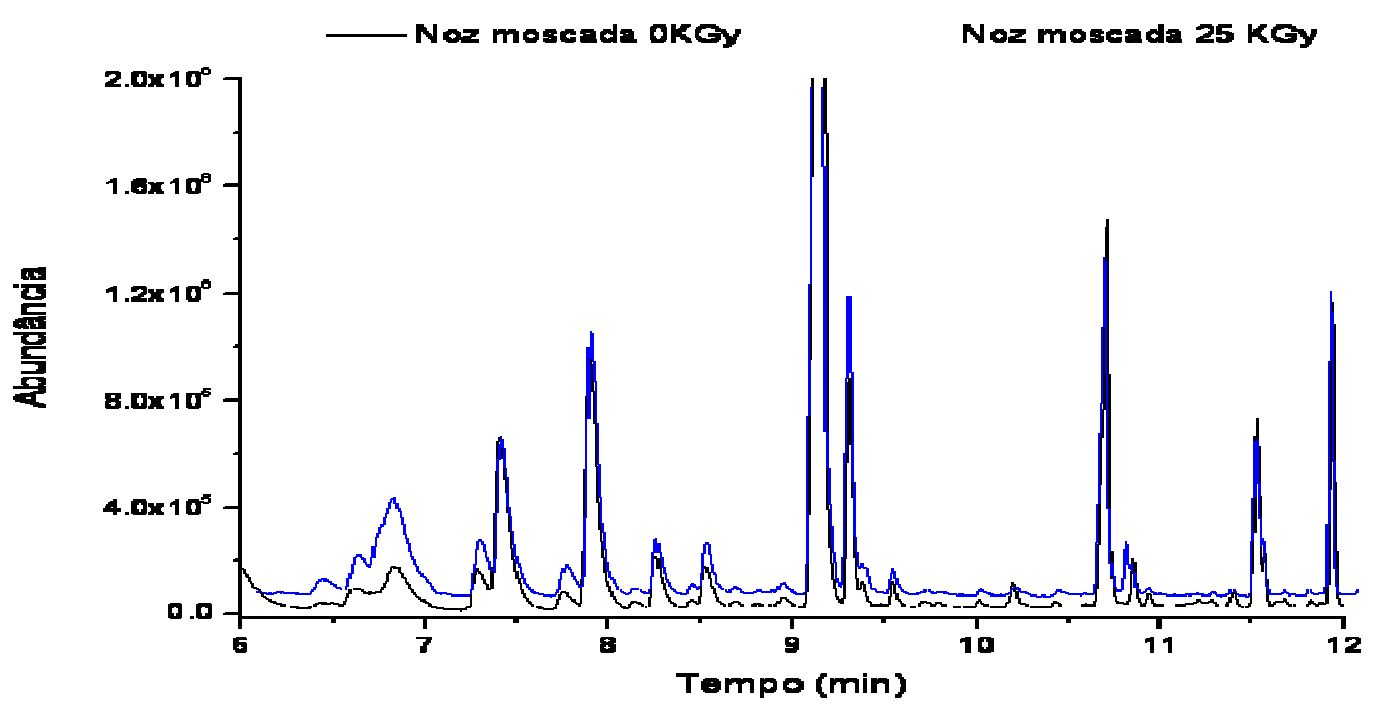

FIGURA 32. Perfis cromatográficos totais da análise da amostra de noz moscada irradiada com a dose de 25kGy sobreposta a uma amostra controle (OkGy) de noz - moscada.

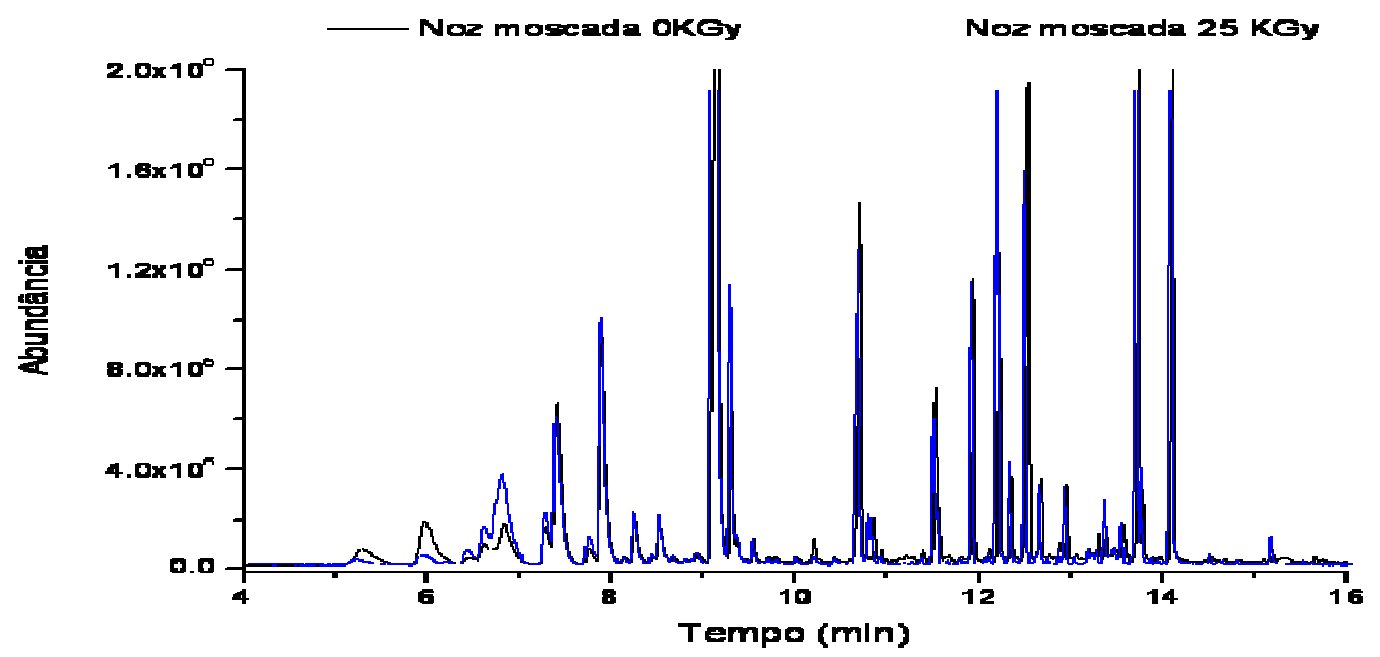

FIGURA 33. Perfis cromatográficos parciais da análise da amostra de noz- moscada irradiada com 25kGy sobreposta à uma amostra controle (0kGy) de noz - moscada. 
TABELA 10. Quantificação dos compostos voláteis das amostras controle (0kGy), das amostras de dose intermediária de 10kGy e das amostras de dose final de 25kGy.

\begin{tabular}{|c|c|c|c|c|c|c|}
\hline Noz-moscada & \multicolumn{3}{|c|}{ Área } & \multicolumn{3}{c|}{ Valor Percentual } \\
\hline & 0kGy & $\mathbf{1 0 k G y}$ & $\mathbf{2 5 k G y}$ & 0kGy & $\mathbf{1 0 k G y}$ & 25kGy \\
\hline 4-Terpineol & 143710775 & 124044210 & 210360879 & 100 & 86,32 & 146,38 \\
\hline alFa-Terpineol & 17608505 & 35826265 & 26879085 & 100 & 203,46 & 152,65 \\
\hline Carlofileno & 32873160 & 54534230 & 27442065 & 100 & 165,89 & 83,48 \\
\hline Miristicina & 38641320 & 67641194 & 71758826 & 100 & 175,05 & 185,70 \\
\hline Elemicina & 39031971 & 69340822 & 92094855 & 100 & 177,65 & 235,95 \\
\hline
\end{tabular}

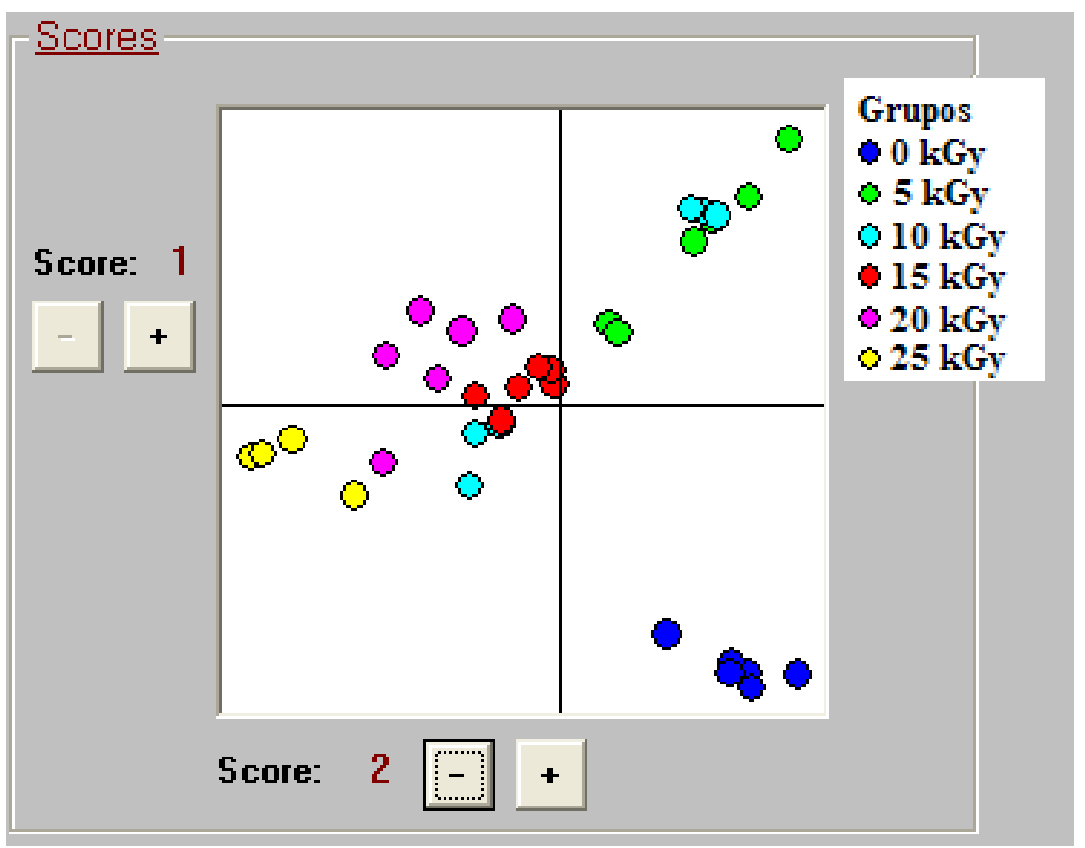

FIGURA 34 - Análise de Variáveis Canônicas de Noz-moscada

É possível deduzir que, houve grande diferença entre as amostras de 5, 10 e 25kGy em relação as amostras controle. As amostras 
irradiadas com 15 e 20kGy apresentaram diferença porém não tão grande com as de 5, 10 e 25kGy.

A noz moscada, ao contrário das demais especiarias, após a irradiação com a dose de 5kGy obteve aumento dobrado dos compostos. Com a dose de 10kGy se observou um aumento de aproximadamente $61 \%$ dos compostos, com exceção do 4-terpineol que obteve decréscimo de 13,68\%. A miristicina (substância tóxica em grandes quantidades, atuante como narcótico) aumentou 75,05\%. Com as doses de 15 e 20 kGy houve pequeno aumento de compostos, porém com comportamento estável. Já com a dose de 25kGy houve um aumento maior ainda da miristicina (85,7\%) e menor do 4-terpineol e alfaterpineol em relação à amostra de $10 \mathrm{kGy}$. As amostras de noz moscada foram repetidas para confirmação de tais resultados. O aumento da miristicina foi reavaliado e confirmado. 


\subsection{Origanum Vulgare - (Orégano)}

TABELA 11. Compostos presentes na amostra controle de orégano (nãoirradiada).

\begin{tabular}{|c|c|c|c|}
\hline Composto & Qual & Composto & Qual \\
\hline 1R-.alpha.-Pinene & 91 & Dodecamethylcyclohexasiloxane & 87 \\
\hline Sabinene & 91 & Gama-Elemene & 97 \\
\hline Beta.-Pinene & 91 & Alpha.-Cubebene & 98 \\
\hline Alpha-Terpinene & 97 & Copaene & 99 \\
\hline Alpha-Terpinene & 97 & $\begin{array}{l}\text { Cyclohexane, 1-ethenyl-1- } \\
\text { methyl-2. }\end{array}$ & 99 \\
\hline $\begin{array}{l}\text { 5-Isopropyl-2- } \\
\text { methylbicyclo[3.1.0]hexan-2-ol }\end{array}$ & 96 & $\begin{array}{l}\text { Benzene, 1,2-dimethoxy-4-(2- } \\
\text { propen }\end{array}$ & 98 \\
\hline Terpinolene & 97 & $\begin{array}{l}\text { Bicyclo[7.2.0]undec-4-ene, } \\
4,11,11\end{array}$ & 96 \\
\hline Terpineol, Z-.beta.- & 96 & Cariofileno & 99 \\
\hline $\begin{array}{l}\text { 4-Isopropyl-1-methyl-2- } \\
\text { cyclohexen-1-ol }\end{array}$ & 96 & Santolina triene & 70 \\
\hline $\begin{array}{l}\text { 4-Isopropyl-1-methyl-2- } \\
\text { cyclohexen-1-ol }\end{array}$ & 93 & Alpha-Guaiene & 96 \\
\hline 4-Terpineol & 97 & (Z)-alpha-Farnesene & 86 \\
\hline (+)-.alpha.-Terpineol (p-menth-1-e & 91 & Alpha.-Caryophyllene & 97 \\
\hline Trans-Piperitol & 96 & Gama-Cadinene & 96 \\
\hline Benzothiazole & 70 & Beta-Cubebene & 86 \\
\hline Methyl thymyl ether & 97 & Beta-Eudesmene & 99 \\
\hline $\begin{array}{l}\text { 2-Isopropyl-1-methoxy-4- } \\
\text { methylbenzene }\end{array}$ & 91 & Alpha-Selinene & 89 \\
\hline Linalyl anthranilate & 91 & Beta-Bisabolene & 98 \\
\hline Cinnamaldehyde & 97 & Antioxidant DBPC & 94 \\
\hline Carvacrol & 94 & Myristicin & 98 \\
\hline Carvacrol & 93 & Gama-Cadinene & 96 \\
\hline
\end{tabular}

Qual: valor qualificador do composto identificado em relação à biblioteca NIST98.L 


\section{- Amostras irradiadas com 5kGy}

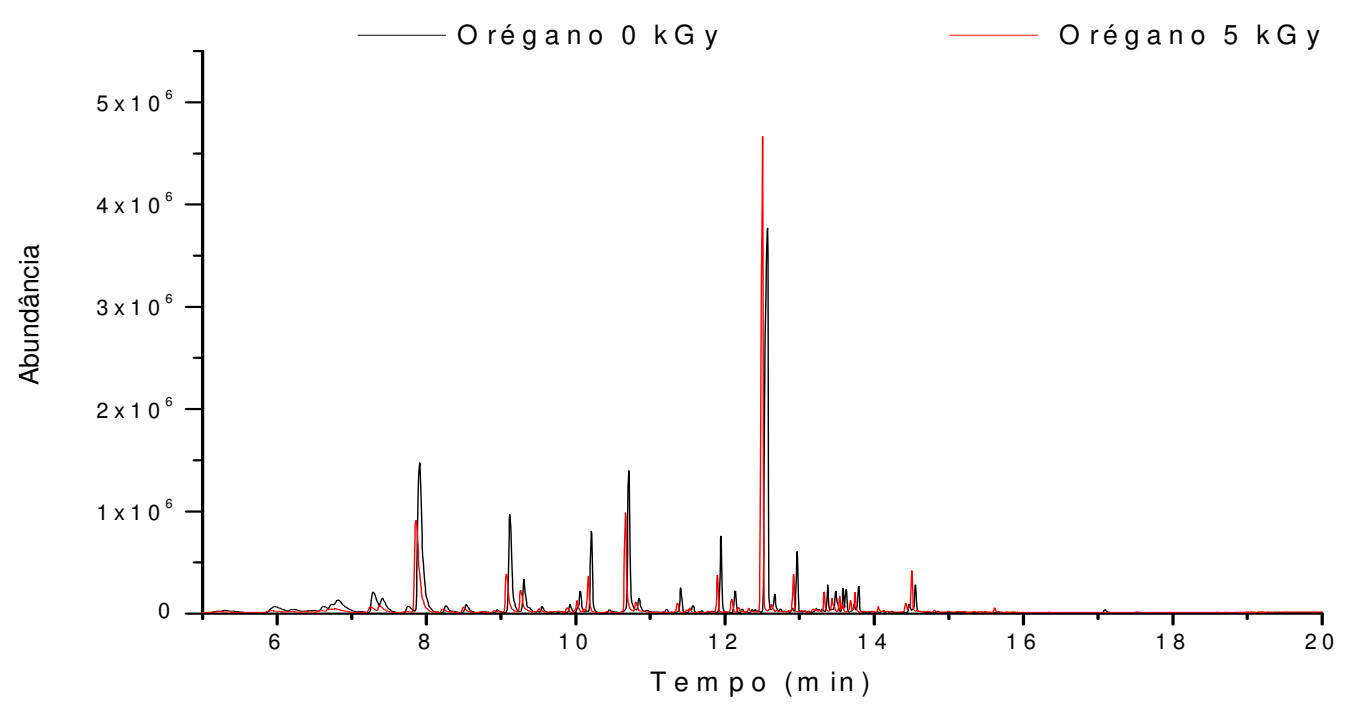

FIGURA 35. Perfis cromatográficos totais da análise das amostras de orégano irradiado com 5kGy sobreposta à uma amostra controle (0kGy) de orégano.

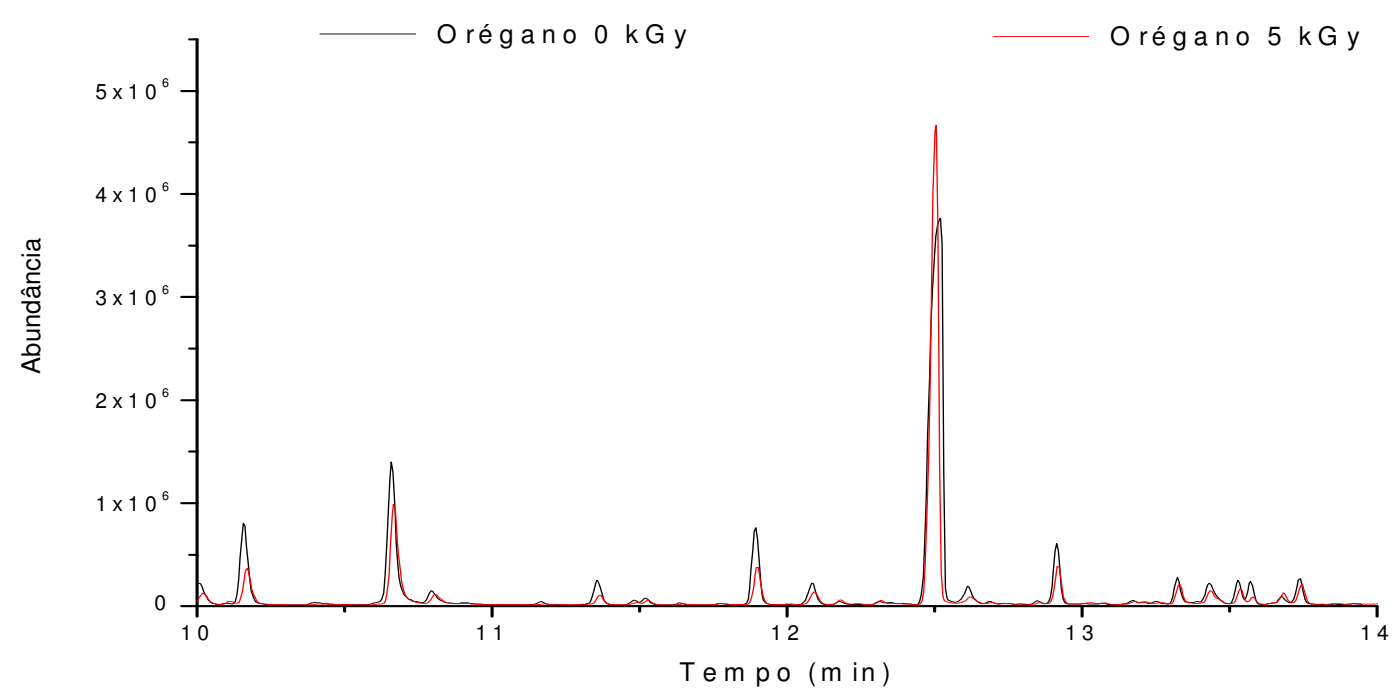

FIGURA 36. Perfis cromatográficos parciais da análise das amostras de orégano irradiado com 5kGy sobreposta à uma amostra controle (0kGy) de orégano 
-Amostras irradiadas com 10kGy

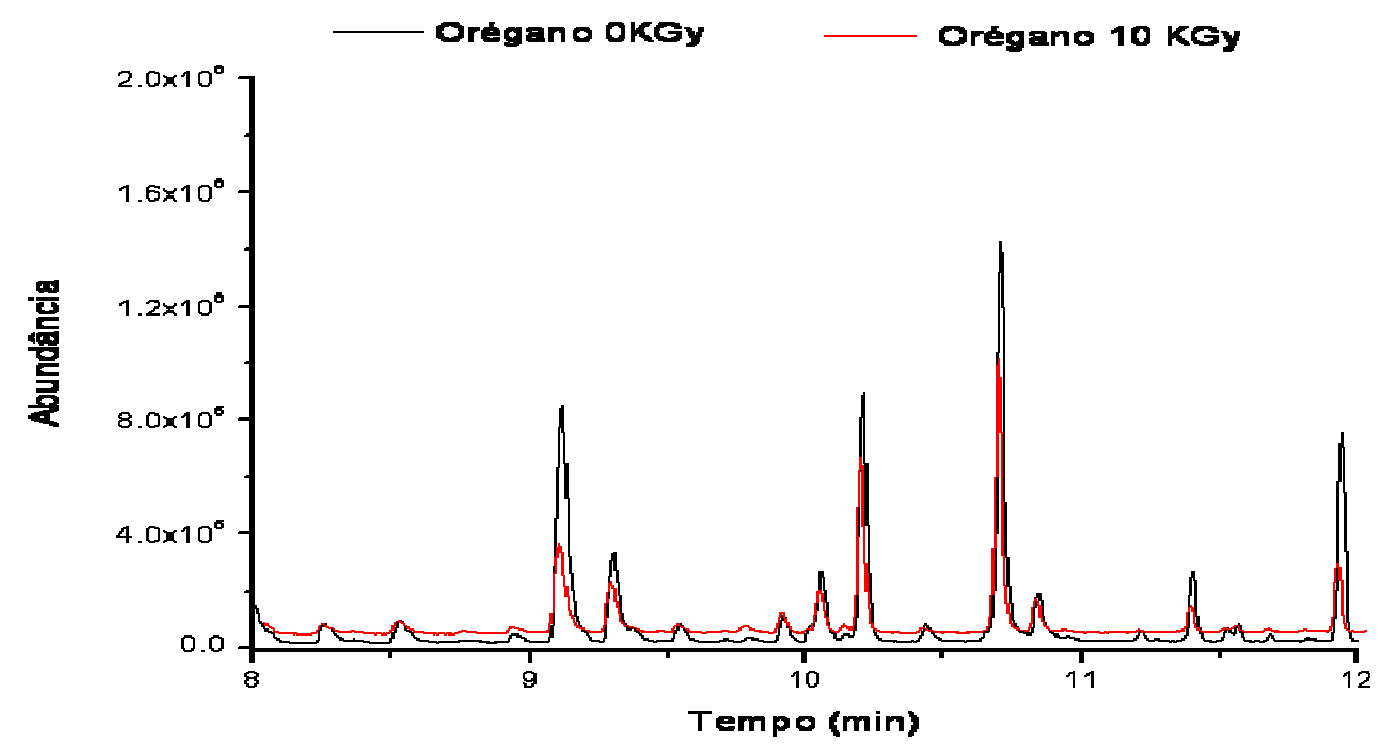

FIGURA 37. Perfis cromatográficos totais da análise da amostra de orégano irradiada com a dose de 10kGy sobreposta à uma amostra controle (0kGy) de orégano.

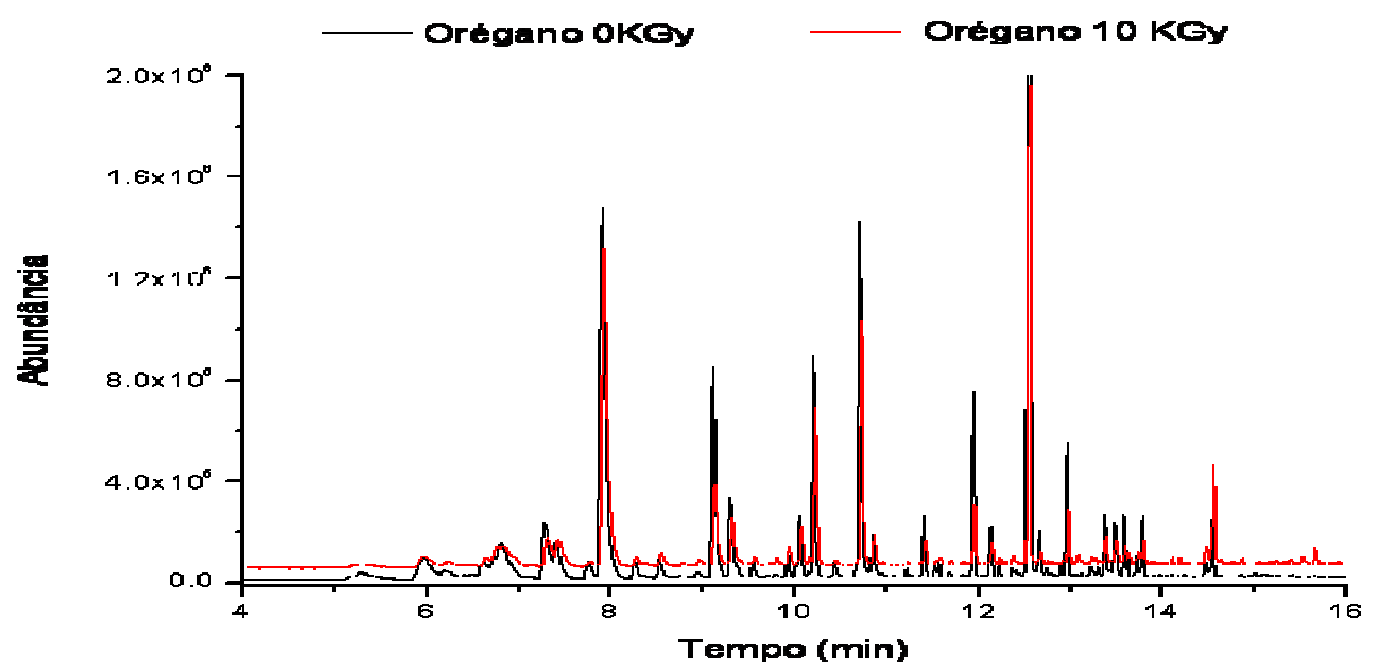

FIGURA 38. Perfis cromatográficos parciais da análise da amostra de orégano irradiada com 10kGy sobreposta à amostra controle (0kGy) de orégano. 
- Amostras irradiadas com 15kGy

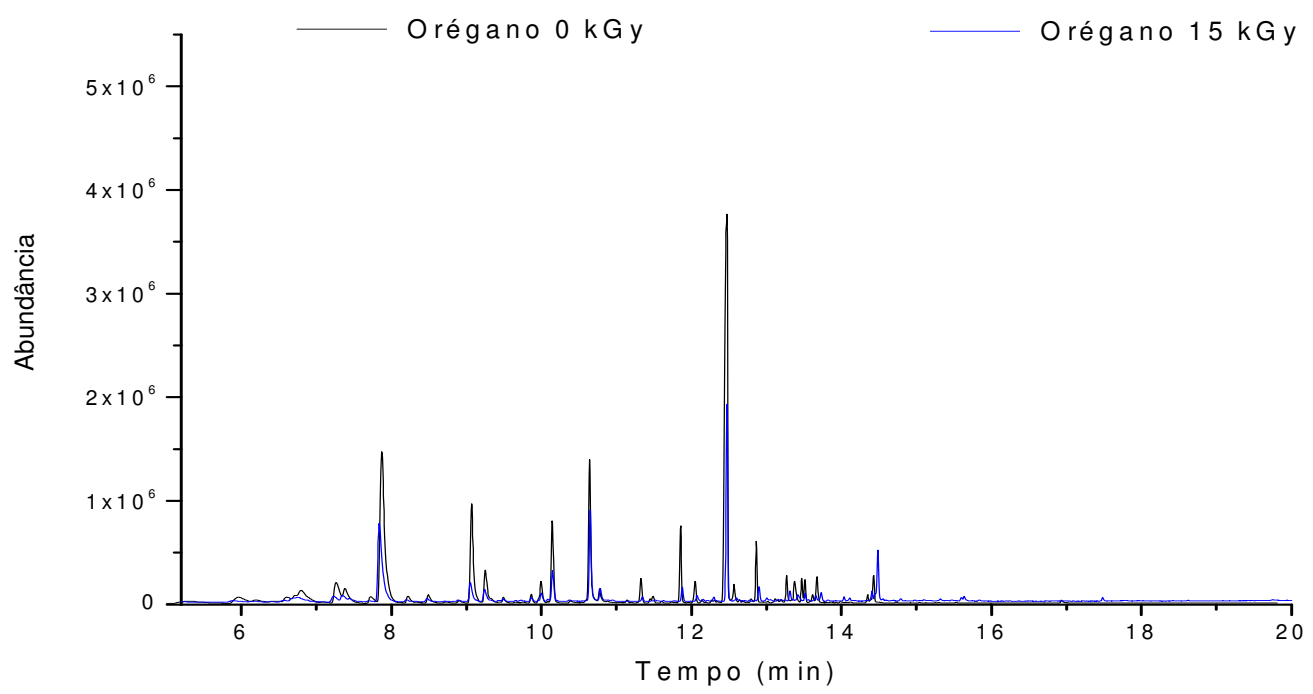

FIGURA 39. Perfis cromatográficos totais da análise da amostra de orégano irradiada com 15kGy sobreposta à amostra controle (0kGy) de orégano.

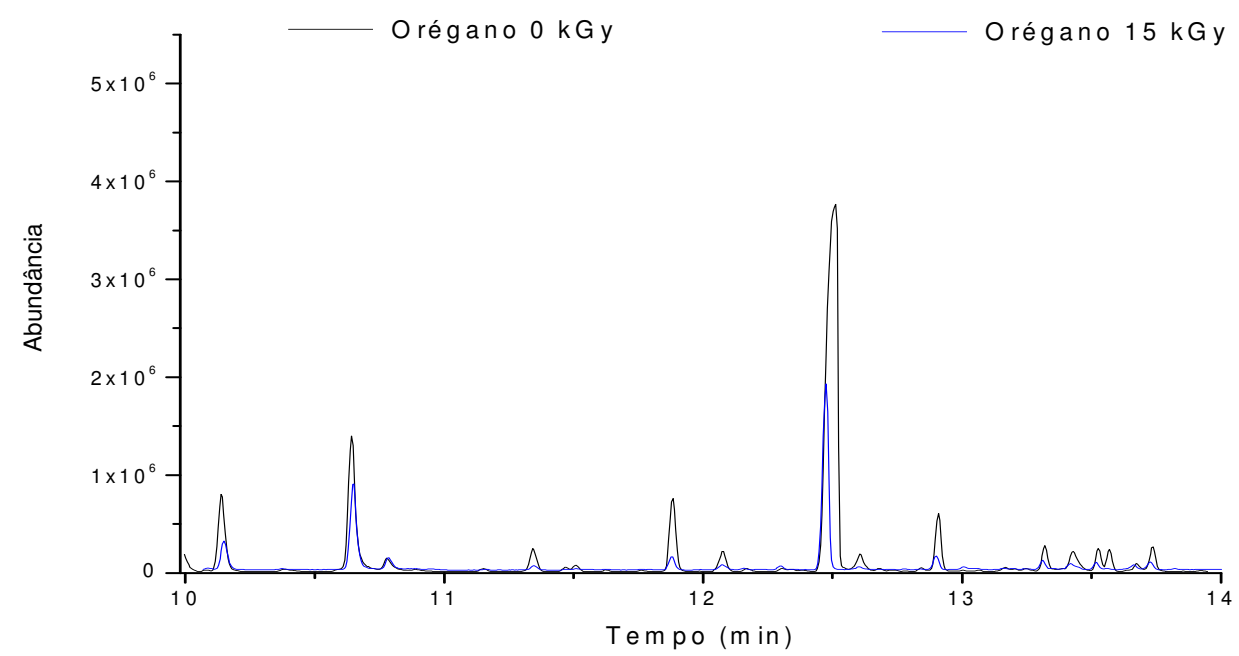

FIGURA 40. Perfis cromatográficos parciais da análise da amostra de orégano irradiada com 15kGy sobreposta à amostra controle (0kGy) de orégano 
-Amostras irradiadas com 20kGy

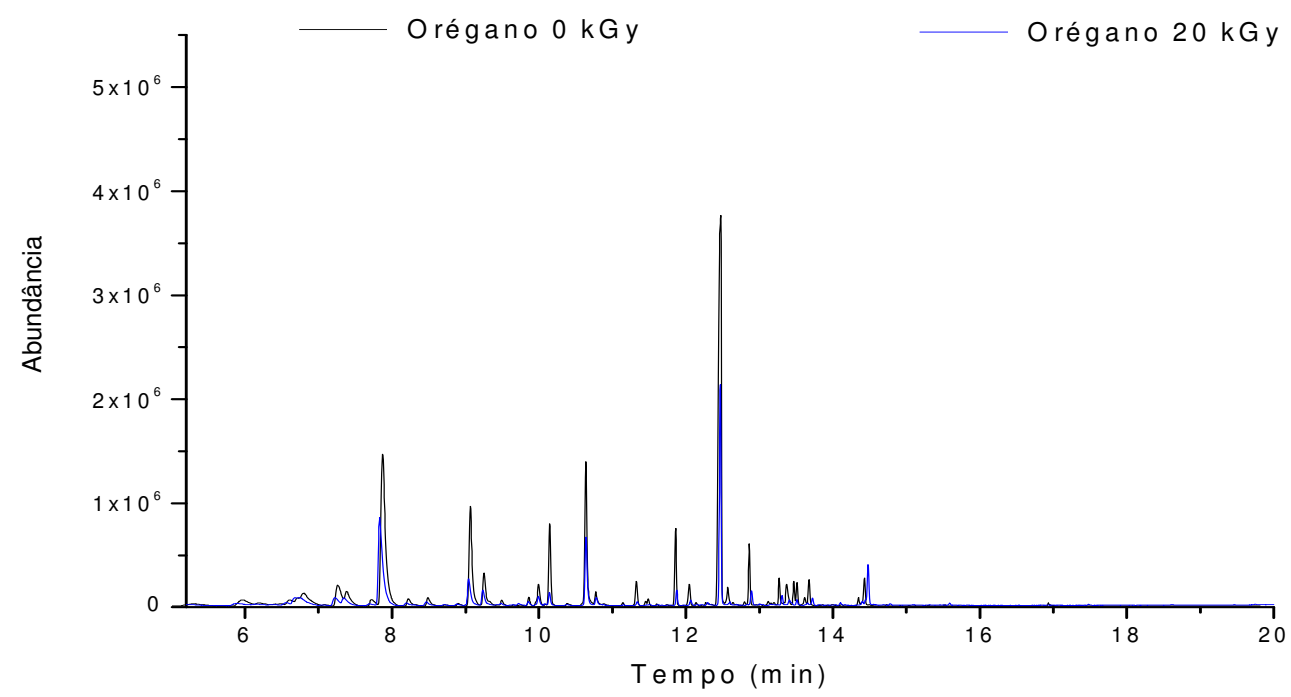

FIGURA 41. Perfis cromatográficos totais da análise da amostra de orégano irradiada com 20kGy sobreposta à amostra controle (0kGy) de orégano

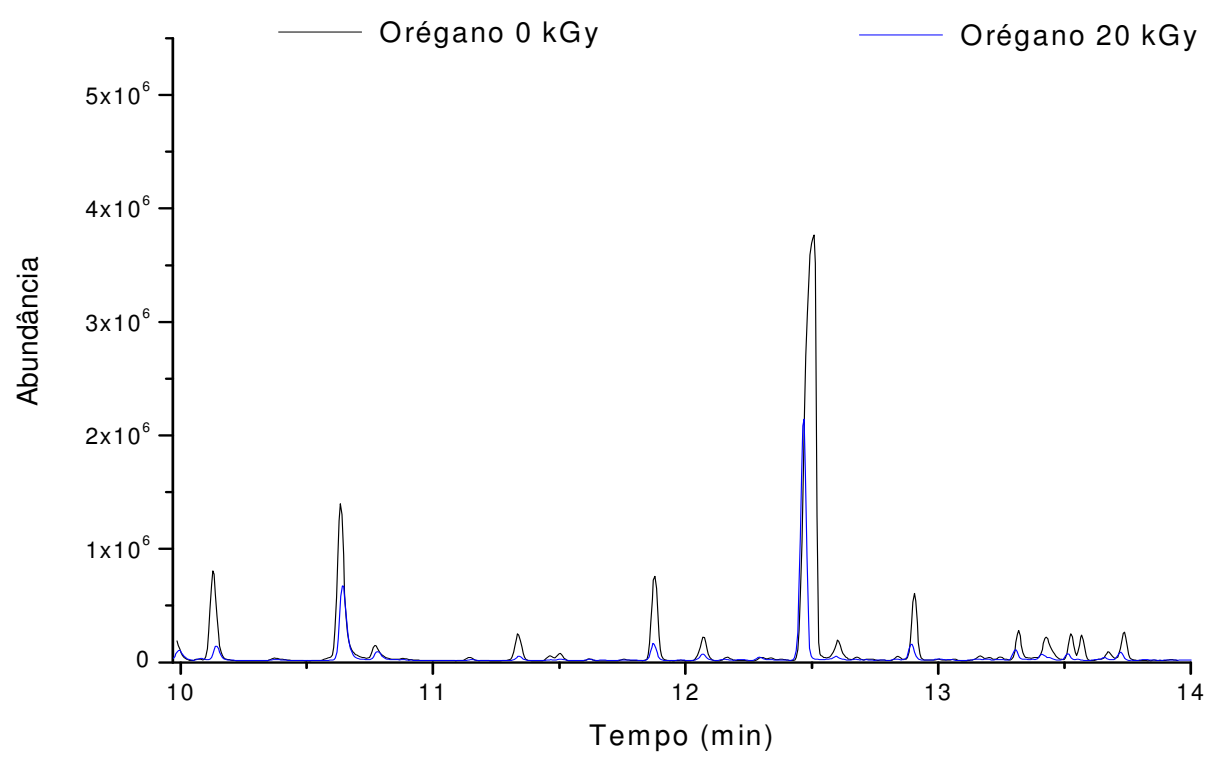

FIGURA 42. Perfis cromatográficos parciais da análise da amostra de orégano irradiada com 20kGy sobreposta à amostra controle (0kGy) de orégano 
- Amostras irradiadas com 25kGy

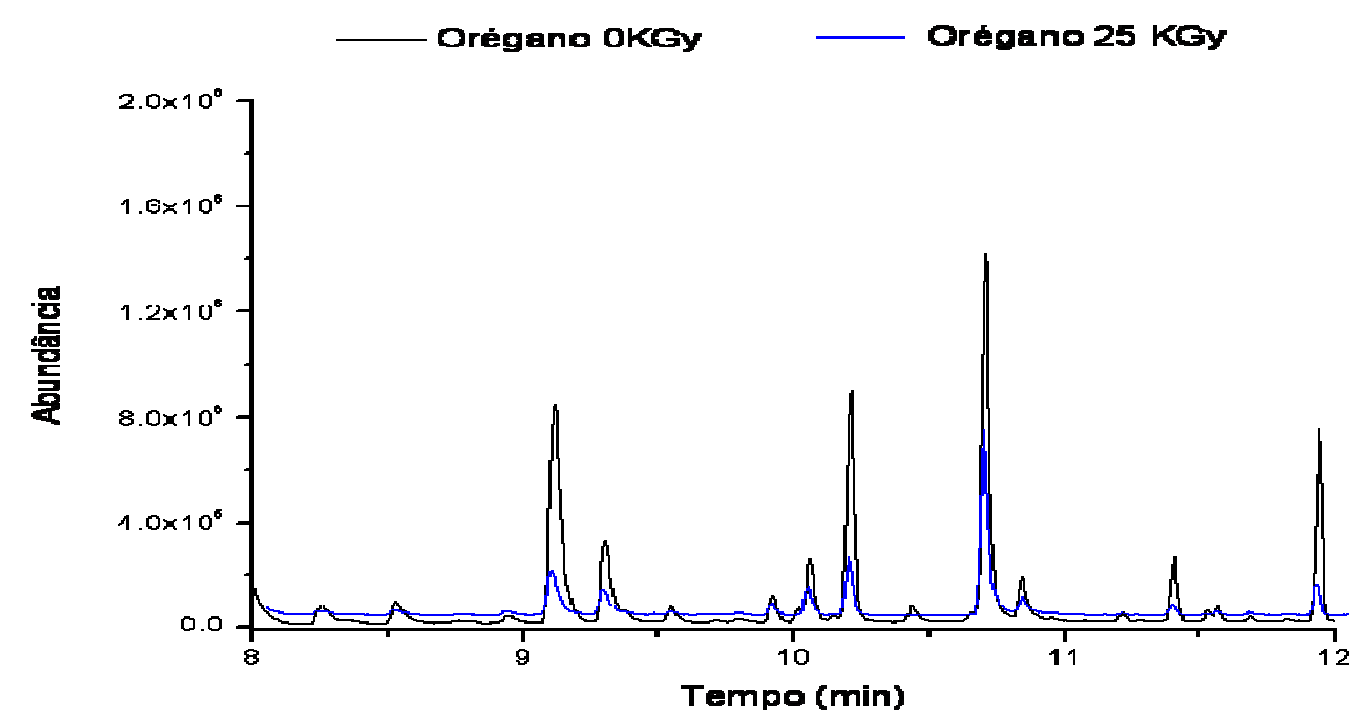

FIGURA 43. Perfis cromatográficos totais da análise da amostra de orégano irradiada com a dose de $25 \mathrm{kGy}$ sobreposta à uma amostra controle (0kGy) de orégano.

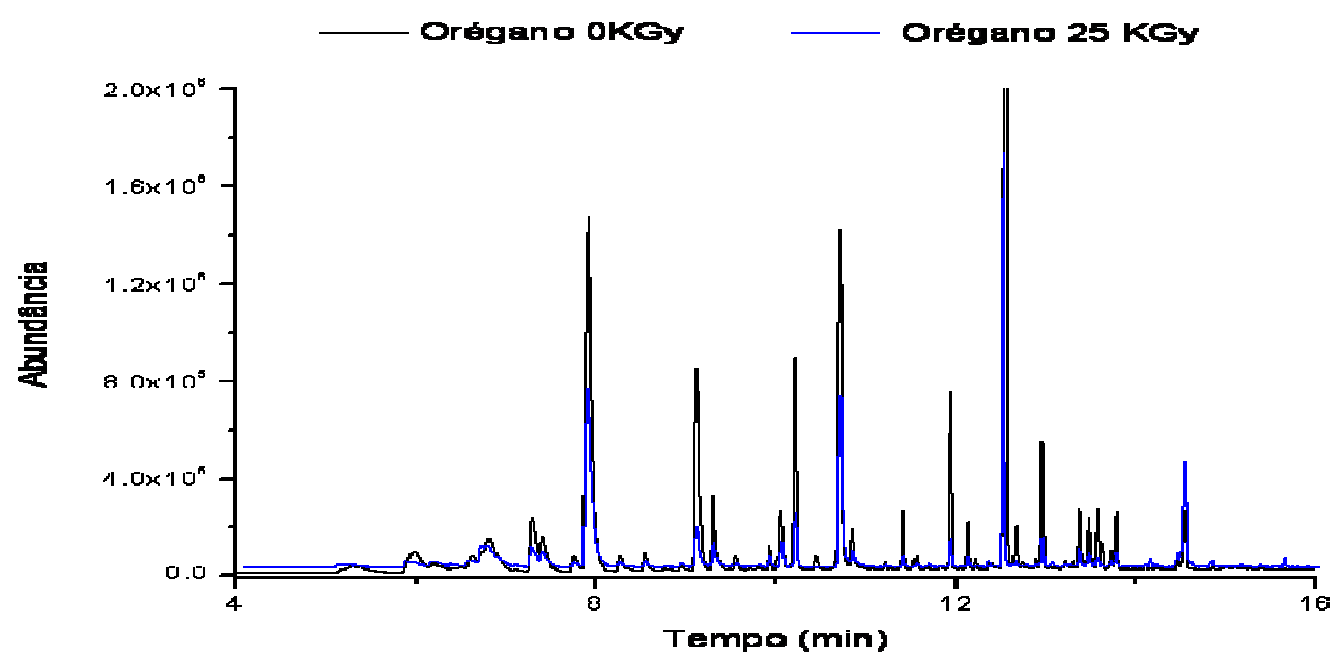

FIGURA 44. Perfis cromatográficos parciais da análise da amostra de orégano irradiada com $25 \mathrm{kG}$ y sobreposta à amostra controle (0kGy) de orégano. 
TABELA 12. Quantificação dos compostos voláteis das amostras controle (0kGy), das amostras de dose intermediária de 10kGy e das amostras de dose final de 25kGy.

\begin{tabular}{|c|c|c|c|c|c|c|}
\hline \multirow[t]{2}{*}{ Orégano } & \multicolumn{3}{|c|}{ Área } & \multicolumn{3}{|c|}{ Valor Percentual } \\
\hline & OkGy & 10kGy & 25kGy & OkGy & 10kGy & 25kGy \\
\hline cis-beta- & 65440545 & 59306158 & 36073116 & 100 & 90,63 & 55,12 \\
\hline 4-Terpinenol & 24697211 & 10410770 & 5039590 & 100 & 42,15 & 20,41 \\
\hline $\begin{array}{l}\text { Linalyl } \\
\text { anthranilate }\end{array}$ & 17575776 & 12445968 & 4322195 & 100 & 70,81 & 24,59 \\
\hline Carvacrol & 286 & & & 100 & 67,95 & 50,94 \\
\hline Caryophyllene & 102256734 & 52240132 & 28040720 & 100 & 51,09 & 27,42 \\
\hline
\end{tabular}

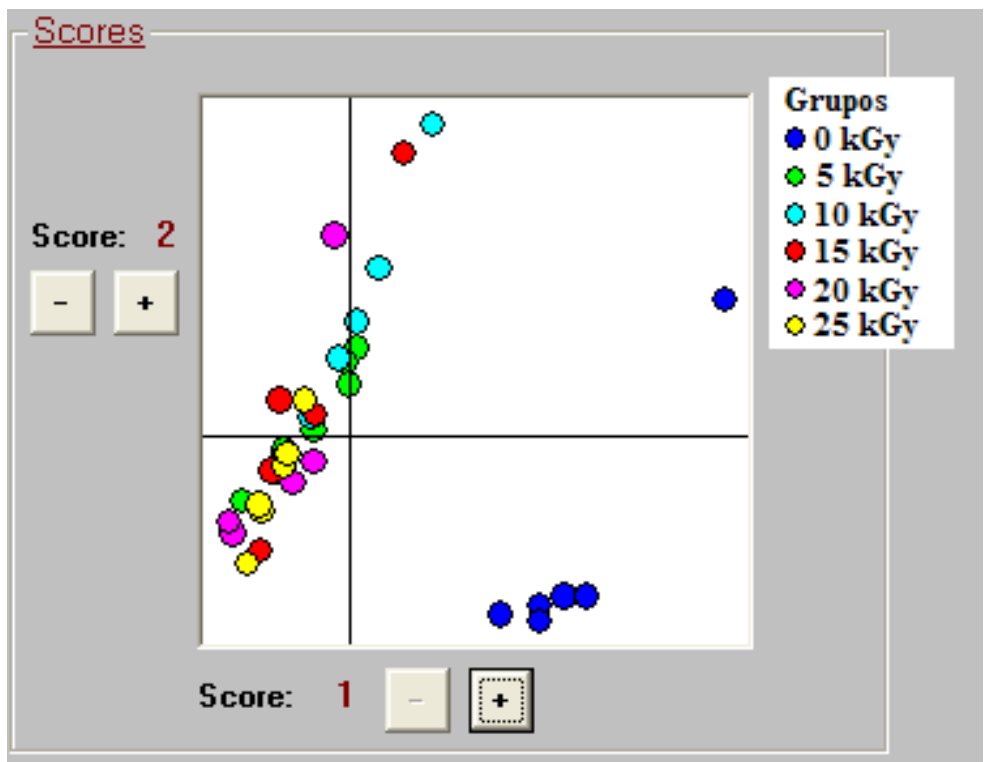

FIGURA 45 - Análise de Variáveis Canônicas do Orégano 
No caso do orégano, existe uma grande diferença entre as amostras controle em relação as demais, porém as amostras de 5, 10, 15, 20 e 25kGy não apresentaram significativa diferença entre si.

As amostras de Origanum Vulgare (Orégano) obteve significativo decréscimo de compostos voláteis, no estudo com as doses de 5, 10, 15, 20 e 25kGy a perda foi progressiva, atingindo a média de $35,7 \%$ de perda com $25 \mathrm{kGy}$.

\subsection{Piper Nigrum (Pimenta-do-reino)}

TABELA 13. Compostos presentes nas amostras controle de pimentado-reino (não-irradiada).

\begin{tabular}{lc|lc}
\hline Composto & Qual & Composto & Qual \\
\hline Sabinene & 87 & Caryophyllene & 98 \\
Gama-Terpinene & 95 & Alpha-Guaiene & 99 \\
5-Isopropyl-2- & 94 & Calarene & 90 \\
methylbicyclo[3.1.0]hexan-2-ol & 95 & Alpha.-Caryophyllene & 97 \\
Terpinolene & 87 & Gama-Cadinene & 95 \\
3-Carene & 97 & Gama-Muurolene & 98 \\
4-Terpineol & 91 & Germacrene D & 97 \\
(+)-.alpha.-Terpineol (p-menth-1-e & 98 & Beta-Eudesmene & 99 \\
Esdragole & 98 & Alpha-Selinene & 95 \\
Propanal, 2-methyl-3-phenyl- & 87 & Beta-Bisabolene & 98 \\
Beta-cis-Ocimene & 90 & Gama-Cadinene, (+)- & 90 \\
Anethole & 93 & Gama-Cadinene, (+)- \\
(+)-4-Carene & & Naphthalene, 1,2,3,4,6,8a- & 95 \\
Alpha.-Cubebene & 98 & hexahydro-1-isopropyl-4,7- & 98 \\
Clovene & & dimethyl- & 97 \\
(+)-Cyclosativene & 96 & Eudesma-3,7(11)-diene & 91 \\
Copaene & 98 & Elemol & 96 \\
Tricyclo[4.1.0.02,4]heptane, 3,3,7 & 90 & Germacrene B & Caryophyllene oxide \\
Beta-Elemen & 99 & 3-Cyclohexen-1-carboxaldehyde, & 83 \\
Alpha-Gurjunene & 97 & 3,4 & 96 \\
\hline *Qual: valor qualificador do composto identificado em & relação à biblioteca NIST98.L &
\end{tabular}

*Qual: valor qualificador do composto identificado em relação à biblioteca NIST98.L 
- Amostras irradiadas com 5kGy.

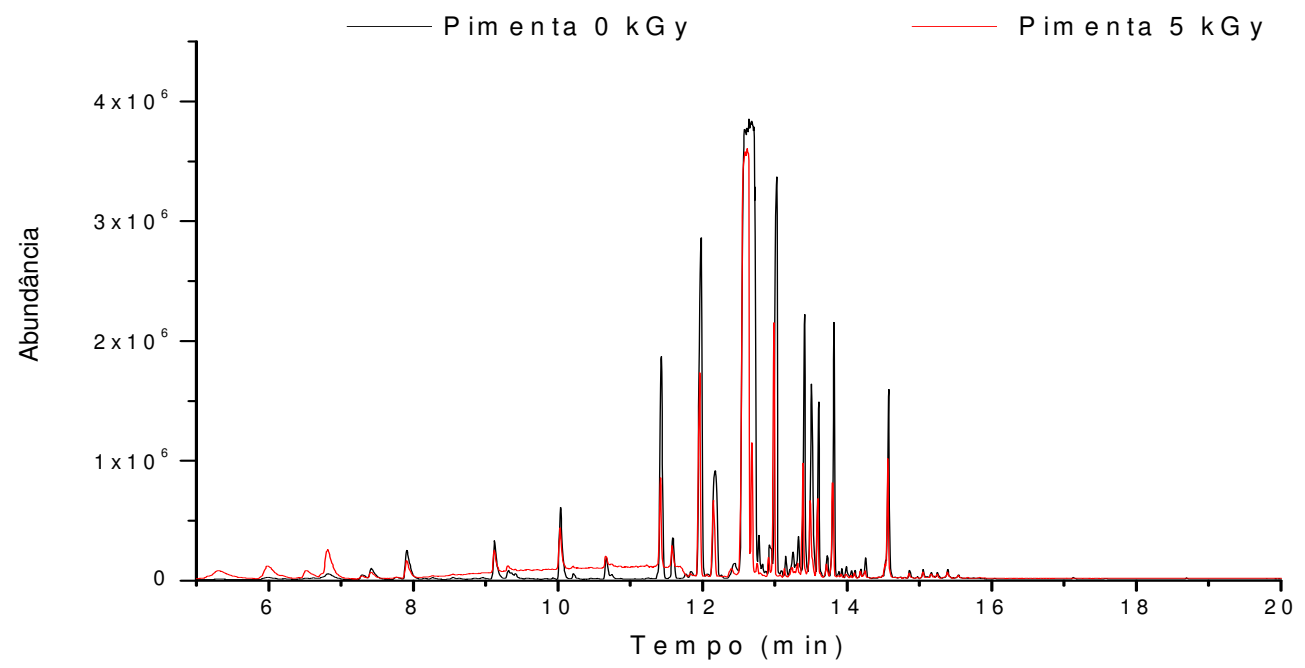

FIGURA 46. Perfis cromatográficos totais da análise da amostra de pimenta-do-reino irradiada com 5kGy sobreposta à amostra controle (OkGy) de pimenta-do-reino.

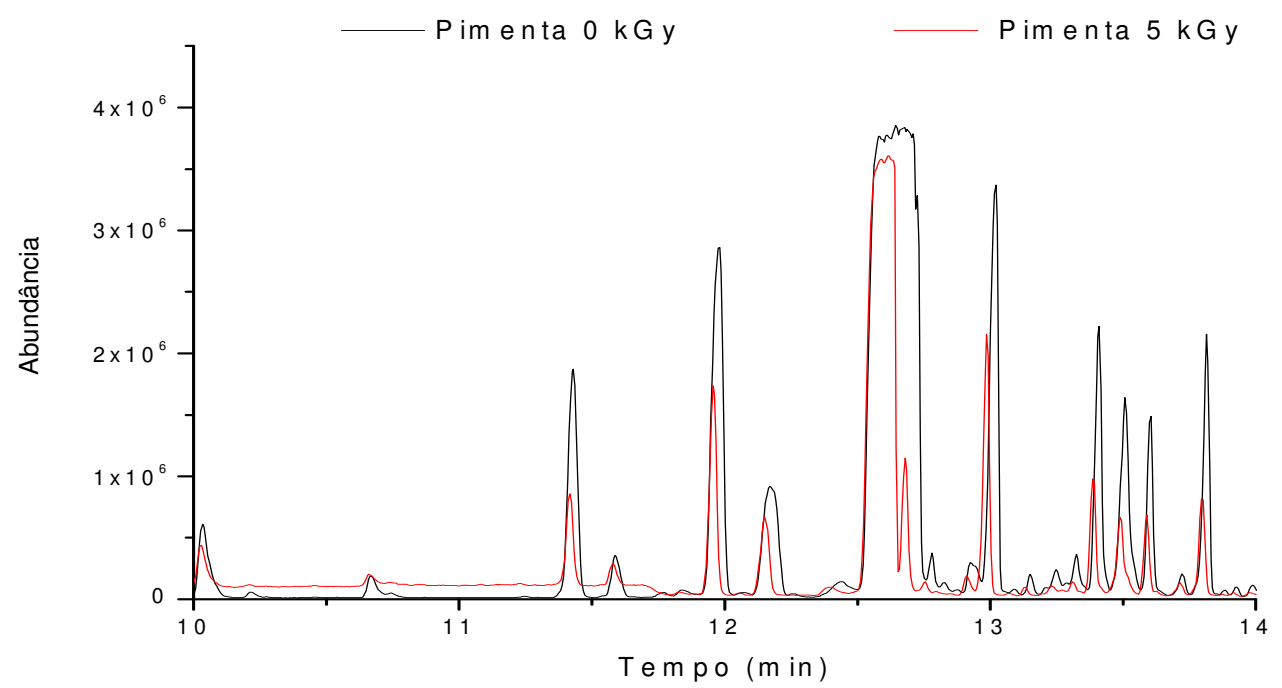

FIGURA 47. Perfis cromatográficos parciais da análise da amostra de pimenta-do-reino irradiada com 5kGy sobreposta à amostra controle (OkGy) de pimenta-do-reino. 


\section{- Amostras irradiadas com 10kGy}

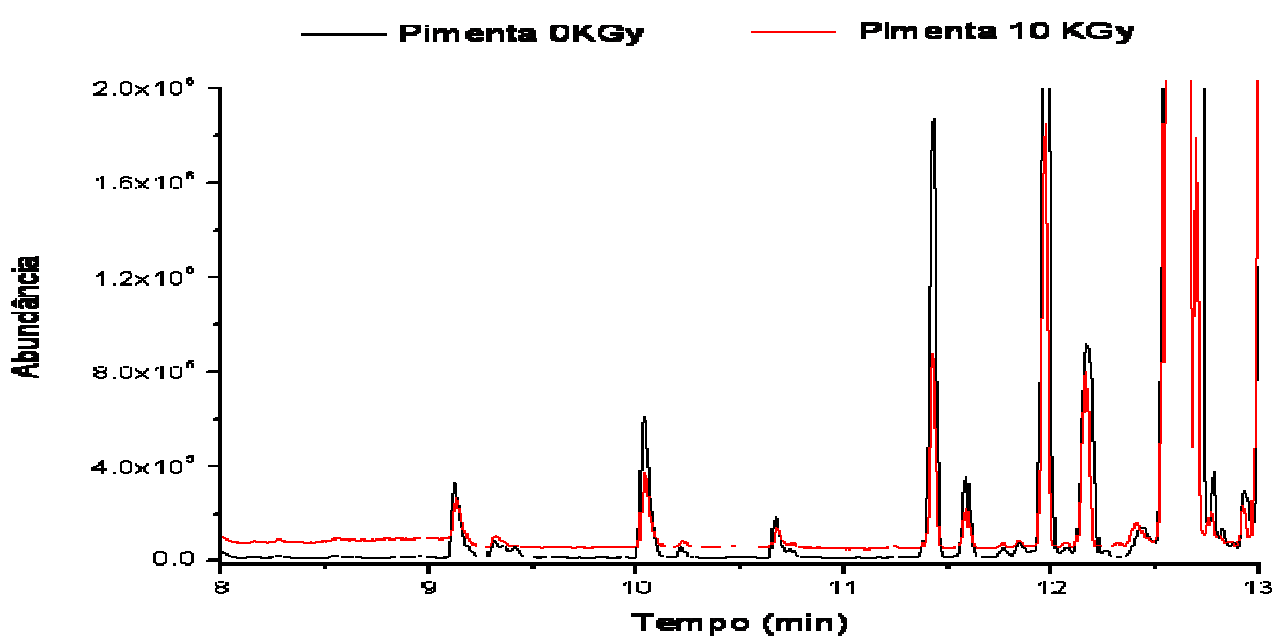

FIGURA 48. Perfis cromatográficos totais da análise da amostra de pimenta-doreino irradiada com a dose de 10kGy sobreposta à uma amostra controle (0kGy) de pimenta-do-reino.

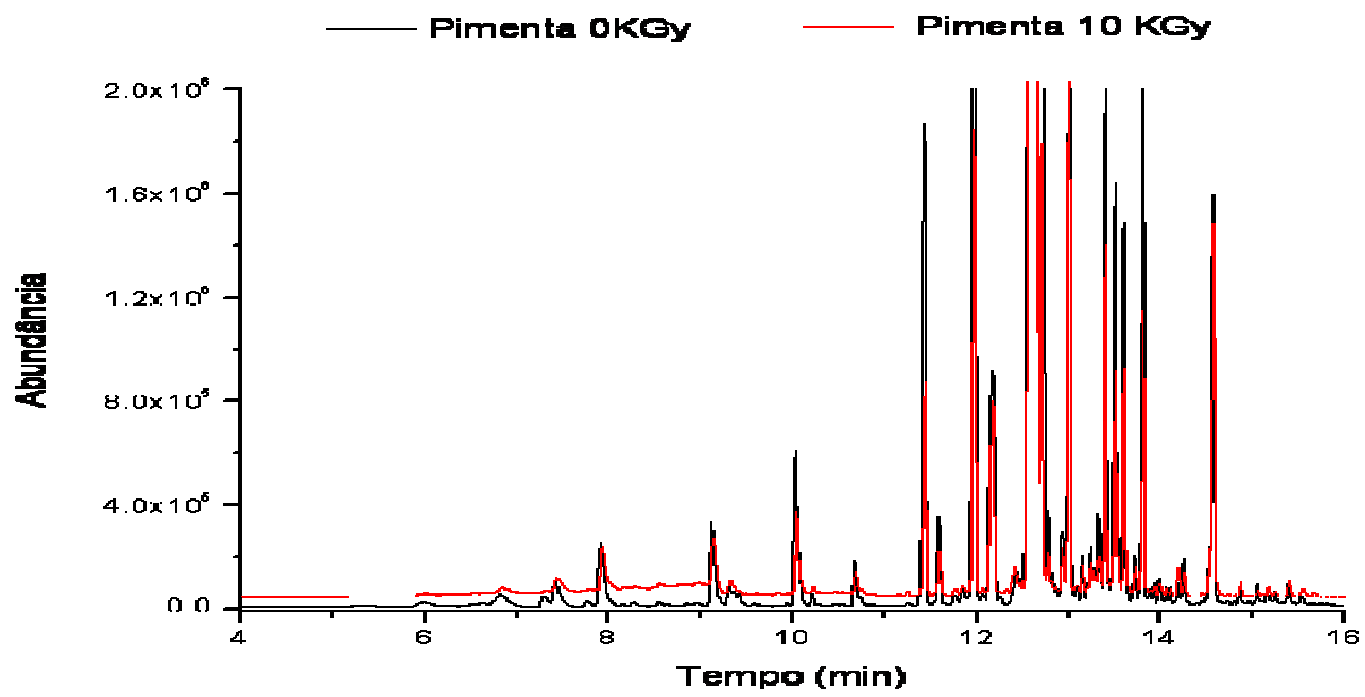

FIGURA 49. Perfis cromatográficos parciais da análise da amostra de pimentado-reino irradiada com 10kGy sobreposta à amostra controle (0kGy) de pimentado-reino. 


\section{- Amostras irradiadas com 15kGy}

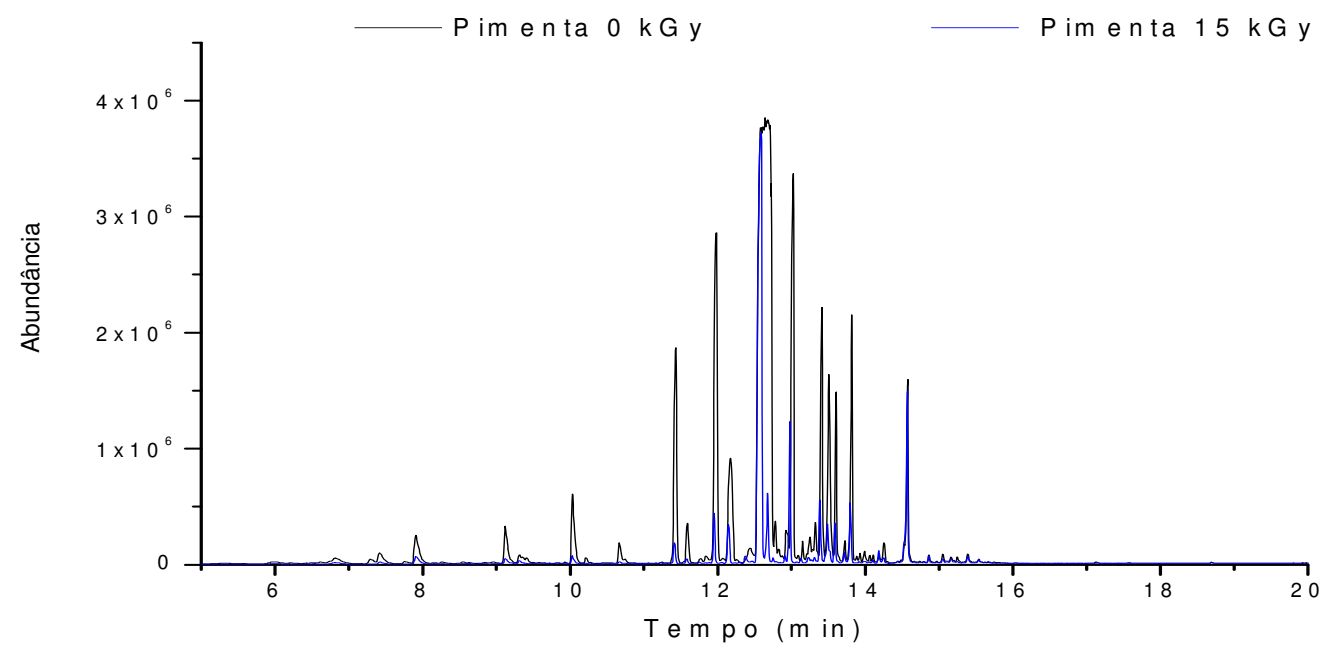

FIGURA 50. Perfis cromatográficos totais da análise da amostra de pimenta-do-reino irradiada com 15kGy sobreposta à amostra controle (OkGy) de pimenta-do-reino.

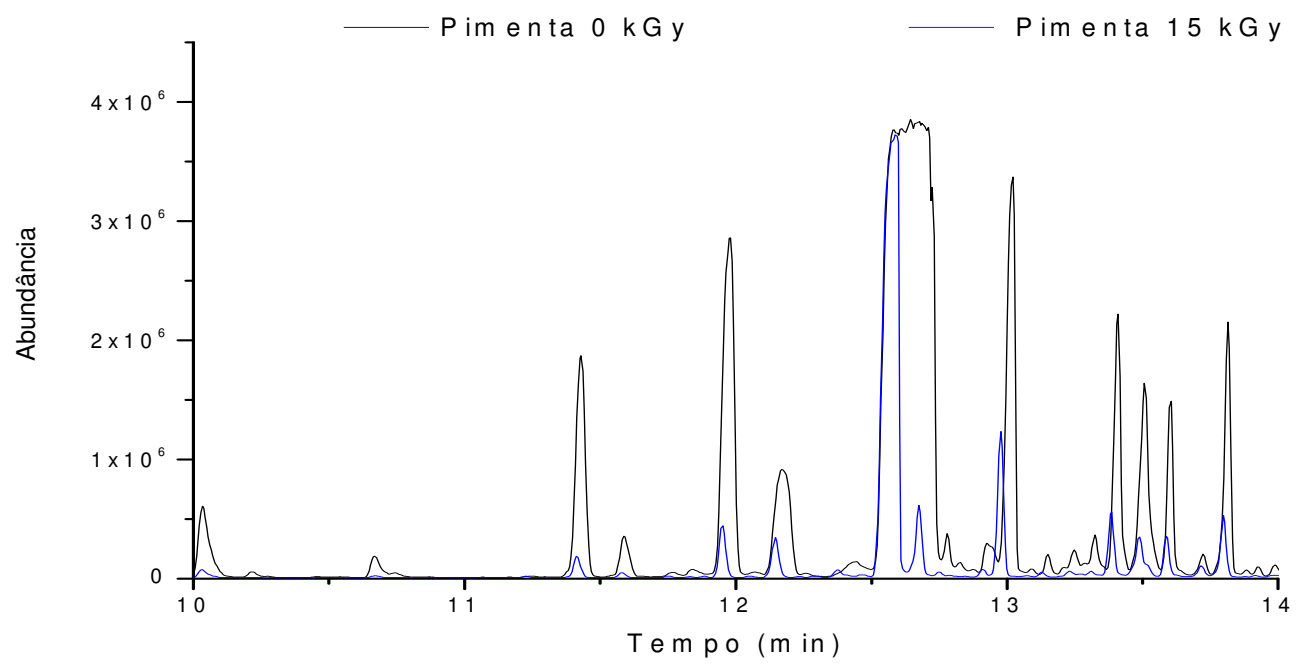

FIGURA 51. Perfis cromatográficos parciais da análise da amostra de pimenta-do-reino irradiada com 15kGy sobreposta à amostra controle (OkGy) de pimenta-do-reino. 
- Amostras irradiadas com 20kGy

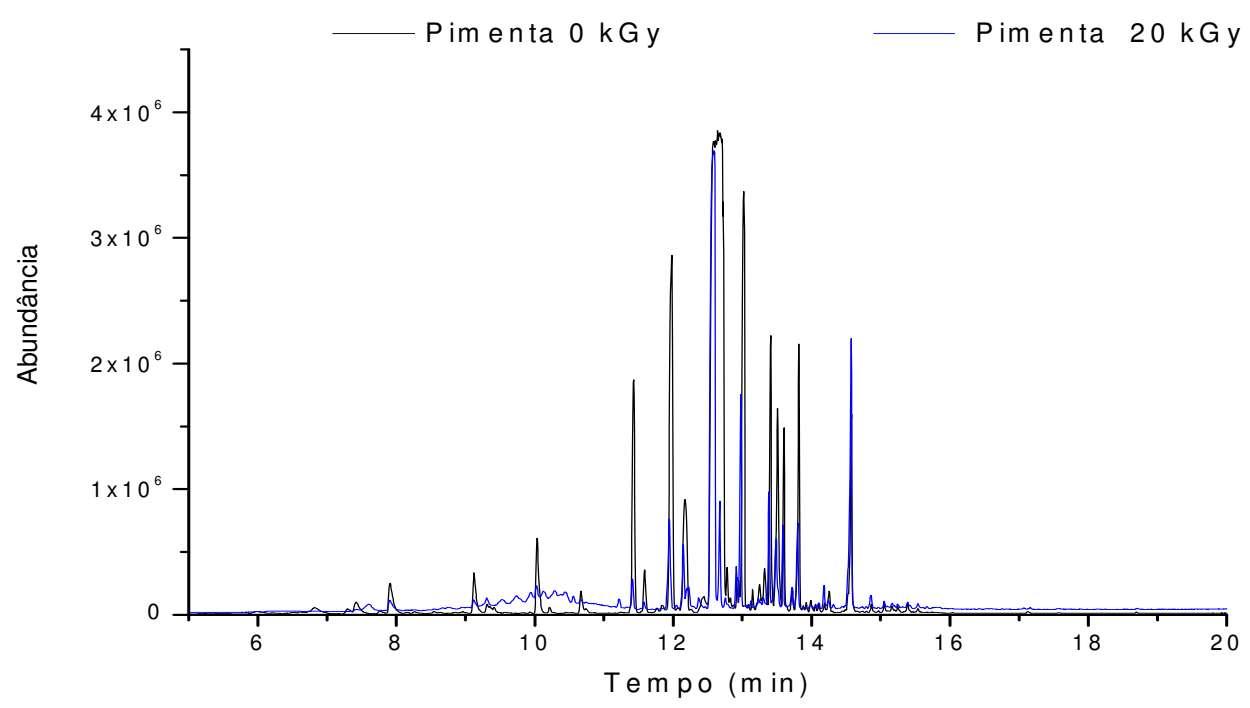

FIGURA 52. Perfis cromatográficos totais da análise da amostra de pimenta-do-reino irradiada com 20kGy sobreposta à amostra controle (OkGy) de pimenta-do-reino.

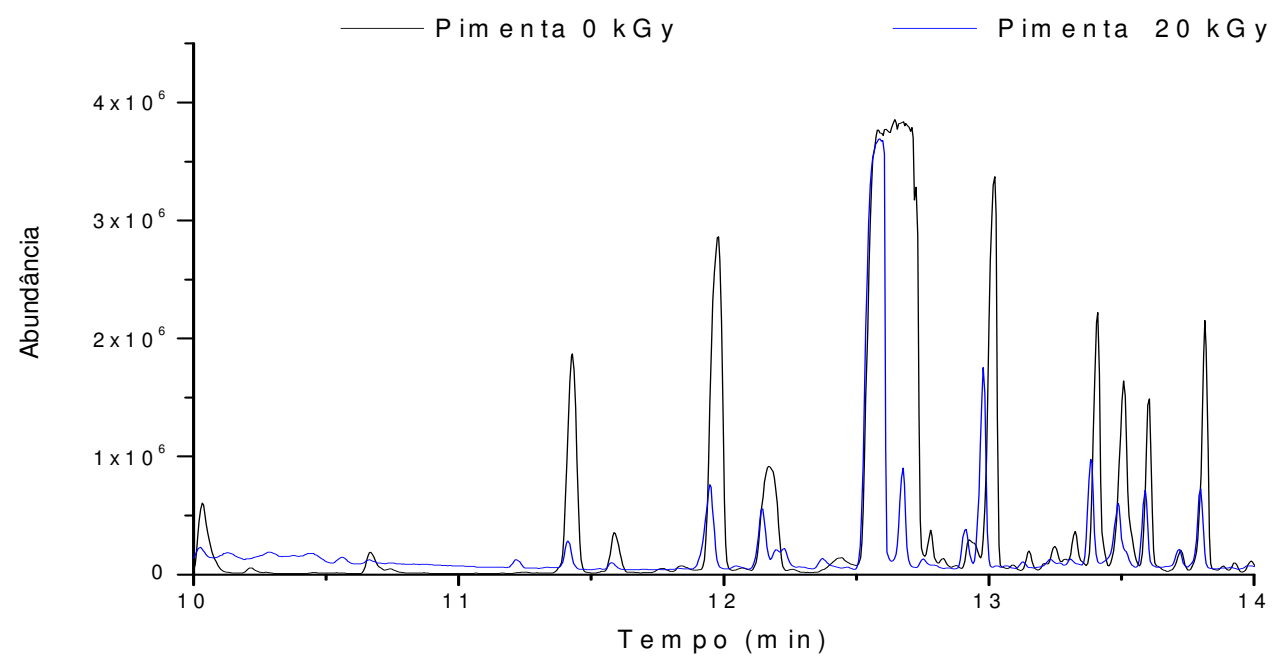

FIGURA 53. Perfis cromatográficos parciais da análise da amostra de pimenta-do-reino irradiada com 20kGy sobreposta à amostra controle (0kGy) de pimenta-do-reino. 
- Amostras irradiadas com 25kGy

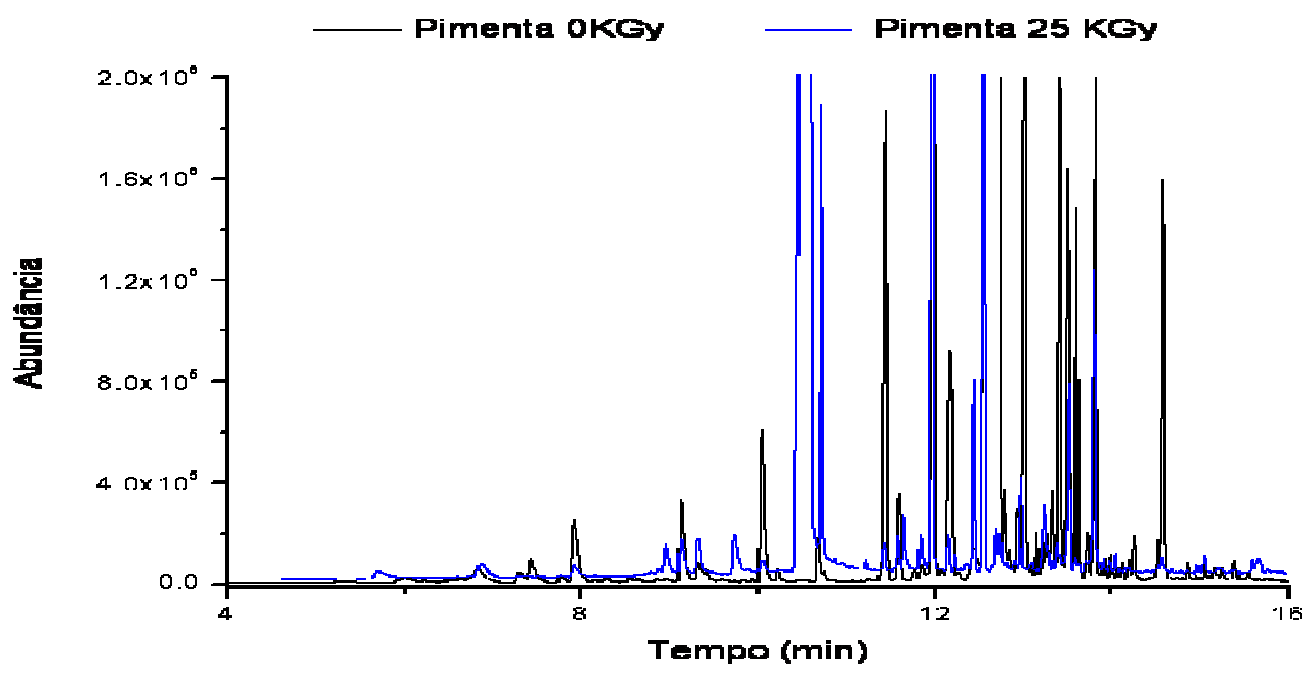

FIGURA 54. Perfis cromatográficos totais da análise da amostra de pimenta-doreino irradiada com a dose de 25kGy sobreposta a uma amostra controle (OkGy) de pimenta-do-reino

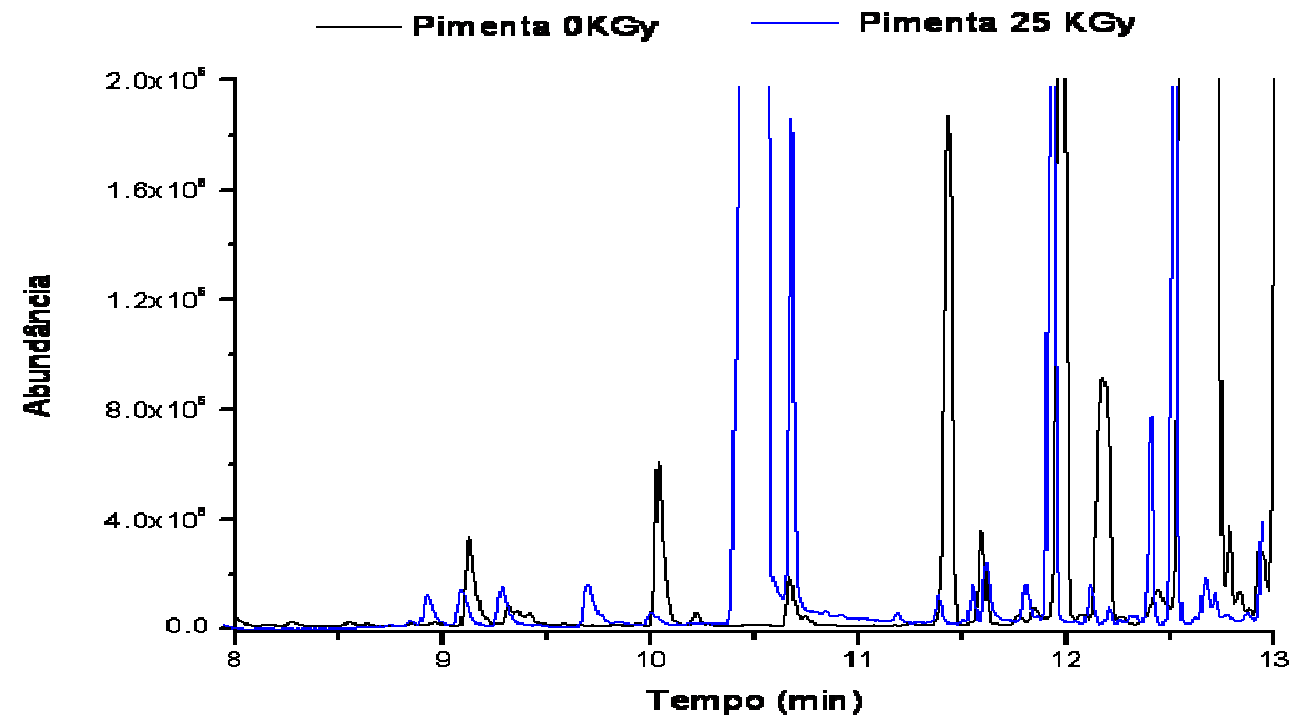

FIGURA 55. Perfis cromatográficos parciais da análise da amostra de pimentado-reino irradiada com 25kGy sobreposto à amostra controle (0kGy) de pimentado-reino. 
TABELA 14. . Quantificação dos compostos voláteis das amostras controle (0kGy), das amostras de dose intermediária de 10kGy e das amostras de dose final de 25kGy.

\begin{tabular}{lccc|ccc}
\hline \multicolumn{1}{c}{$\begin{array}{c}\text { Pimenta-do- } \\
\text { reino }\end{array}$} & \multicolumn{3}{c}{ Área } & \multicolumn{3}{c}{ Valor Percentual } \\
\hline & 0kGy & 10kGy & 25kGy & 0kGy & 10kGy & 25kGy \\
4-Carene & 45410972 & 16478950 & 10217064 & 100 & 36,29 & 22,5 \\
alpha-cubebene & 83635421 & 38103505 & 25776974 & 100 & 45,56 & 30,82 \\
-alpha.- & 73846482 & 46352347 & 46270111 & 100 & 62,77 & 62,66 \\
$\begin{array}{l}\text { Caryophyllene } \\
\text { Beta-eudesmene }\end{array}$ & 38514940 & 22284309 & 26428287 & 100 & 57,86 & 68,62 \\
$\begin{array}{l}\text { Caryophyllene } \\
\text { oxide }\end{array}$ & 29144322 & 26898231 & 82405255 & 100 & 92,29 & 282,75 \\
\hline
\end{tabular}

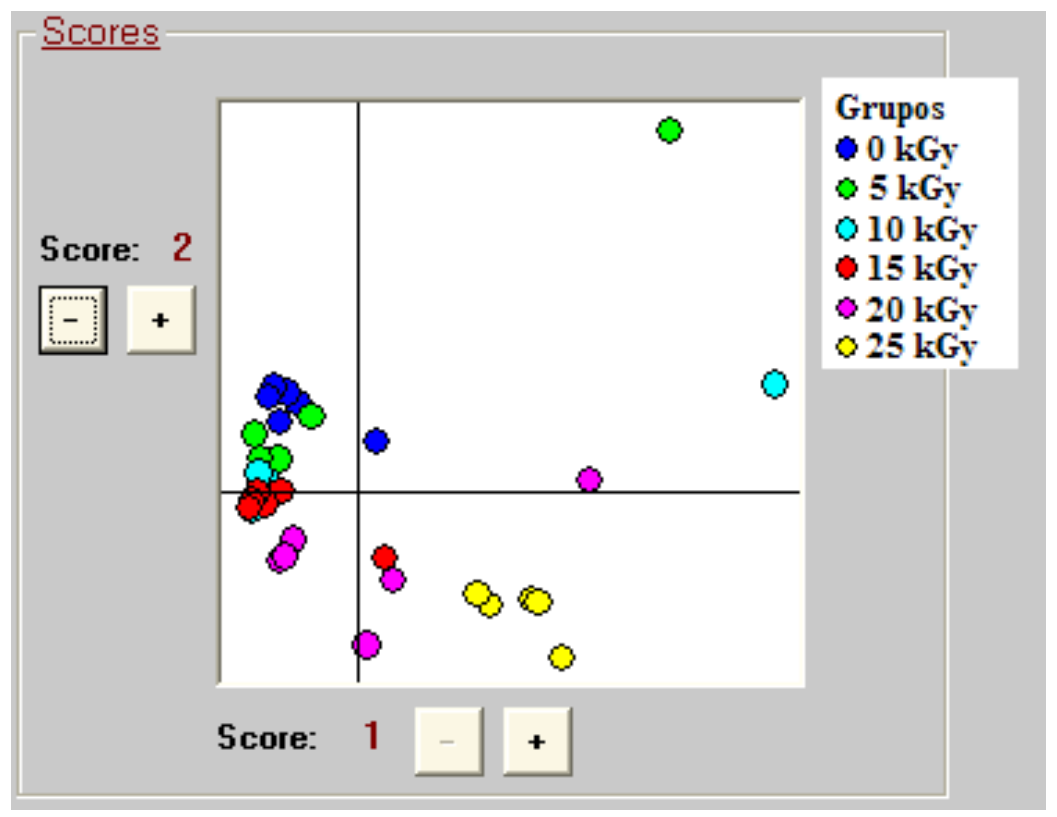

FIGURA 56. Análise de Variáveis Canônicas de Pimenta-do-reino

Observando o gráfico da FIGURA 56, pode-se concluir que as amostras controle se mantiveram juntamente com as amostras de 5 e 
25 kGy, a diferença está entre as amostras de 15 e 20kGy, onde as mesma se distanciaram significativamente das amostras controle e de 25kGy.

As amostras de Piper Nigrum (pimenta-do-reino) obtiveram significativo decréscimo dos compostos voláteis, principalmente quando as amostras foram submetidas à dose de 25kGy atingindo a média máxima de 46,15\% de perda, exceto o aumento de quase $200 \%$ do óxido de cariofileno quando a amostra foi submetida à dose de 25kGy.

\section{Amostras estocadas por 2 meses}

As amostras estocadas por 2 meses após a irradiação apresentaram, de um modo geral, o aumento dos picos cromatográficos. Porém, esse aumento parece ficar menos evidente com o aumento da dose de radiação. Pode-se observar isso nos picos das amostras de pimenta-do-reino (FIGURAS 57, 58 e 59). 

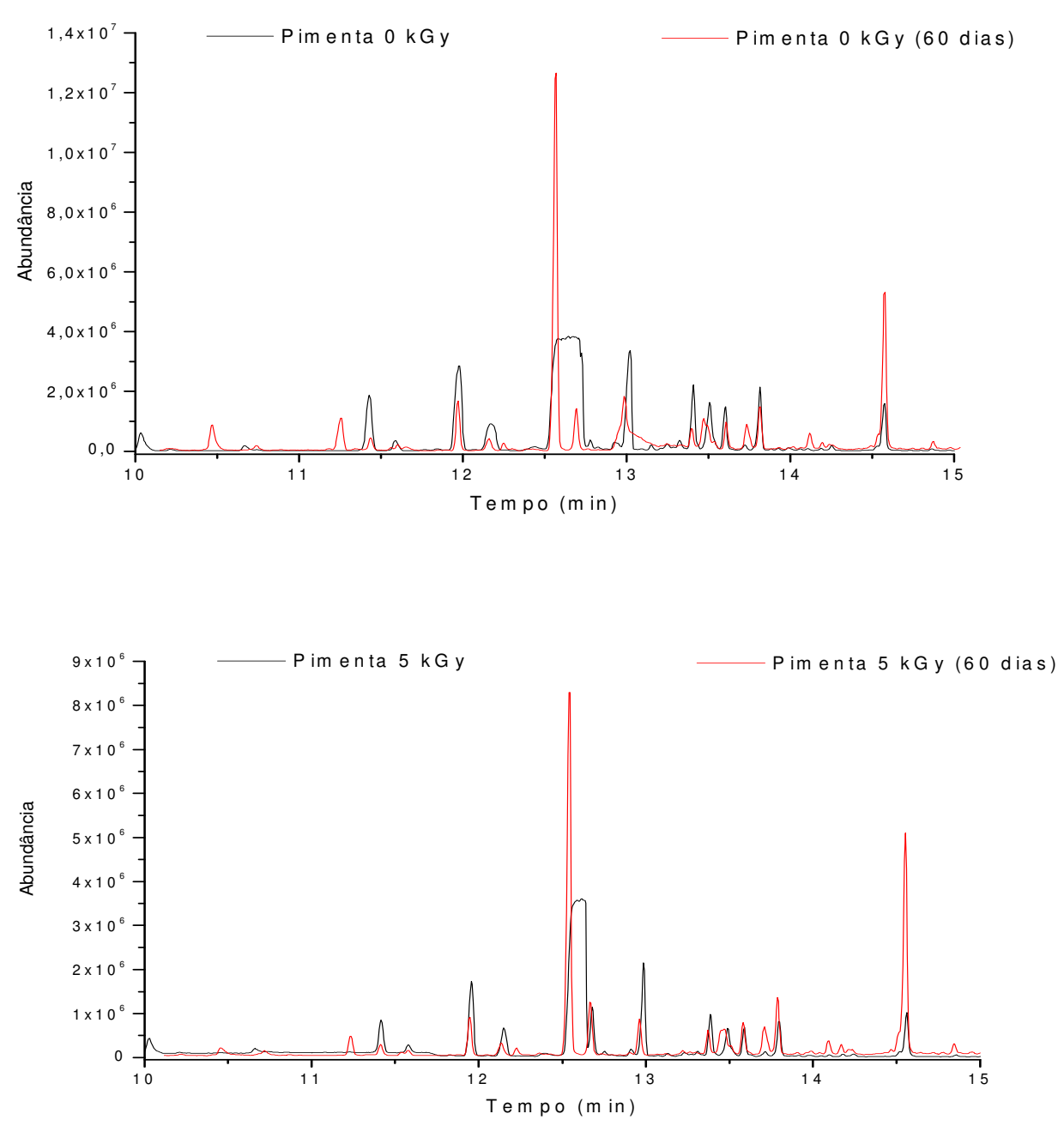

FIGURA 57 - Picos cromatográficos parciais das amostras de pimetado-reino irradiadas com 0 e 5kGy após estocagem. 

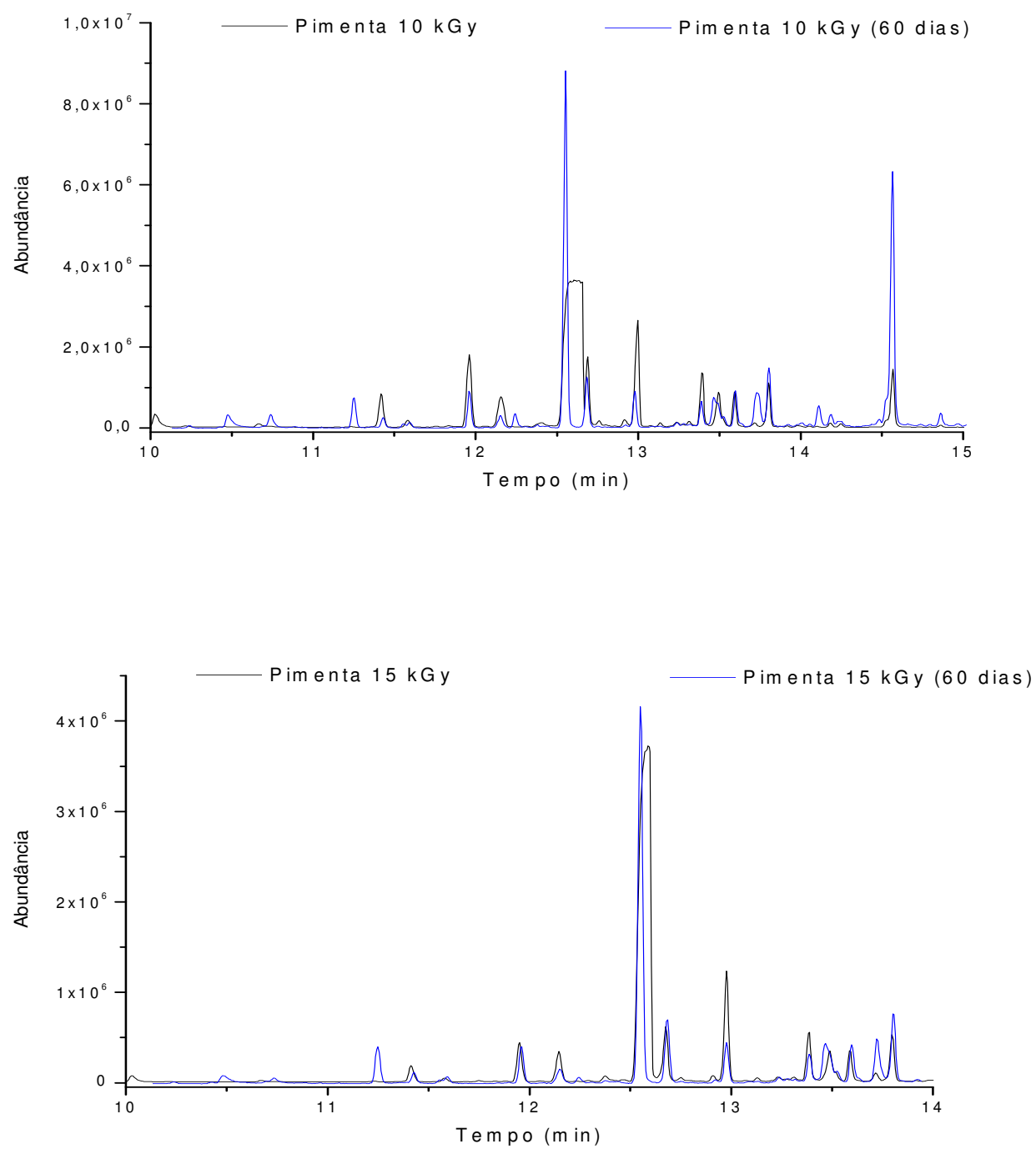

FIGURA 58 - Picos cromatográficos parciais das amostras de pimetado-reino irradiadas com 10 e 15kGy após estocagem. 

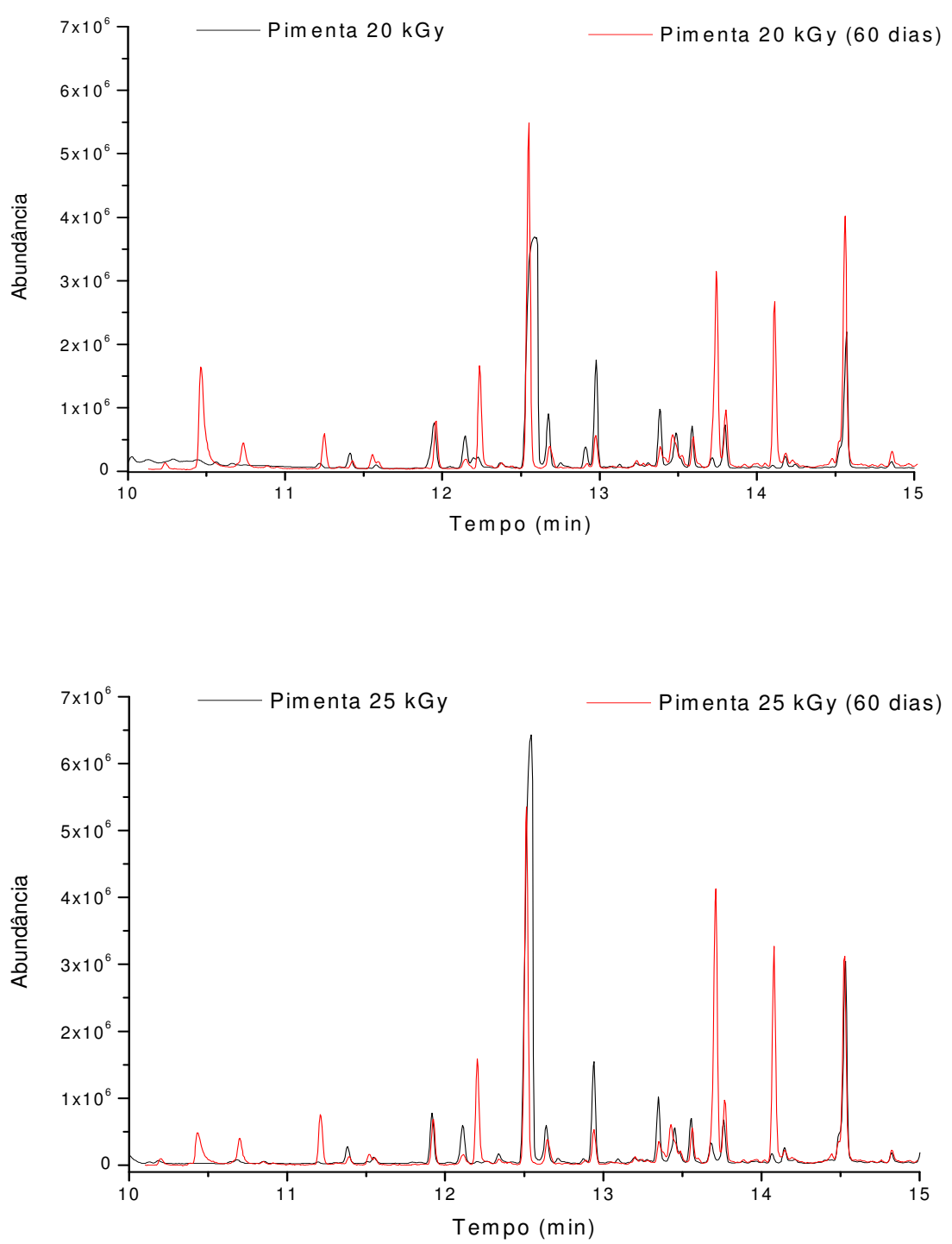

FIGURA 59 - Picos cromatográficos parciais das amostras de pimetado-reino irradiadas com 20 e 25kGy após estocagem.

\subsection{Amostras controle e irradiadas das embalagens}

Os resultados mostrados nas FIGURAS 60 e 61 indicaram que não houve mudança significativa no comportamento dos compostos 
voláteis das embalagens quando estas foram submetidas a doses variadas de radiação $(5,10,15,20$ e 25kGy).

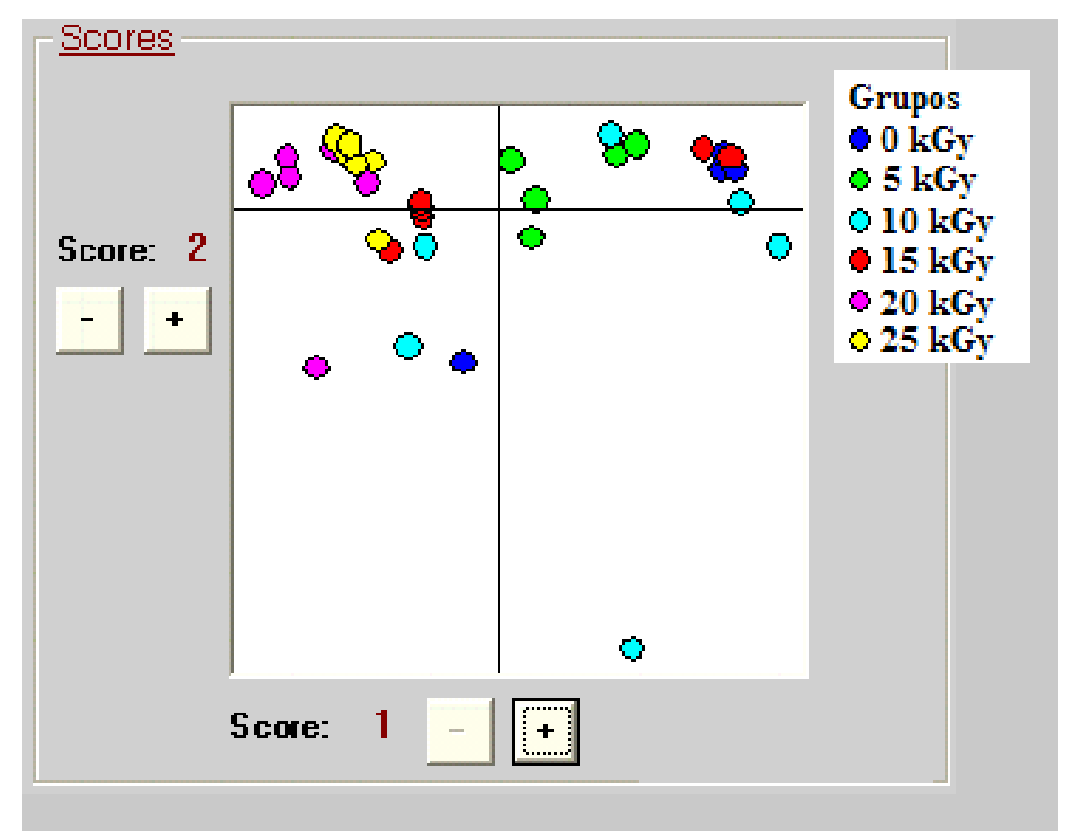

FIGURA 60 - Análise de Variáveis Canônicas (Método de Correlação) das amostras de embalagem

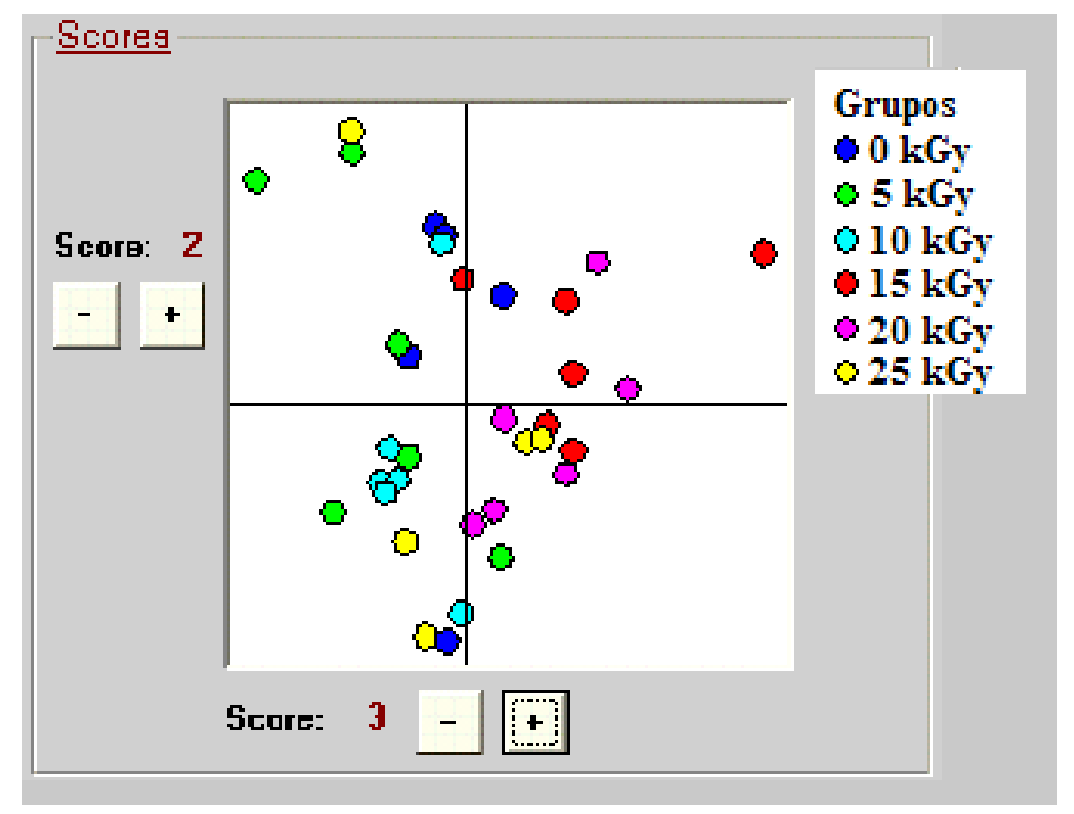

FIGURA 61 - Análise de Covariância das amostras de embalagem 


\section{CONCLUSÕES}

De acordo com os resultados obtidos, pode-se concluir que:

- O tratamento por irradiação gama de ${ }^{60} \mathrm{Co}$ provocou diminuições dos compostos voláteis da maioria das especiarias estudadas.

- É conclusivo que, em relação às amostras analisadas de Cinnamomum Zeylanicum (canela) as perdas de compostos voláteis foram progressivas uma vez que, aumentando a dose de radiação na especiaria as perdas foram maiores. De acordo com esses resultados, no que se refere à perda de voláteis, a melhor dose para aplicação seria de até 5kGy.

- Houve aumento de compostos voláteis de Myristica Fragans (Nozmoscada) quando esta foi submetida à dose de radiação.

- Torna-se necessário após reavaliação do aumento da substância miristicina, uma avaliação de toxicidade em relação aos níveis obtidos da substância neste estudo.

- De acordo com tais resultados, no que se refere à perda de voláteis, a melhor dose para aplicação seria de 15 a 20kGy, pois obteve o comportamento mais estável quando comparado as demais amostras analisadas.

- De acordo com os resultados das amostras de Origanum Vulgare, no que se refere à perda de voláteis, a melhor dose para aplicação seria de até $5 k G y$, pois a perda dos voláteis aumentava conforme a dose também aumentava. 
- De acordo com os resultados das amostras de Piper Nigrum, no que se refere à perda de voláteis, a melhor dose para aplicação seria de até 5kGy.

- As amostras irradiadas e avaliadas após período de 2 meses de estocagem mostraram aumento de picos cromatográficos nas doses mais baixas e nas amostras controle. Tornando tal aumento menos evidente nas doses mais altas de 20 e $25 k G y$.

- As análises das embalagens em que as especiarias foram irradiadas demonstrou nenhuma interferência significativa nos resultados obtidos das análises das especiarias.

- Tais resultados sugerem que a irradiação gama de ${ }^{60} \mathrm{Co}$ interfere na qualidade sensorial das especiarias, ou pelo aumento de compostos voláteis (no caso da noz-moscada) ou devido a perda de compostos (no caso das demais especiarias), uma vez que, estes compostos atuam especificamente no odor das especiarias. Havendo perda dos mesmos, a qualidade olfatória da especiaria é prejudicada e, quando houve aumento dos compostos, a qualidade olfatória natural da especiaria foi alterada.

É notório durante o processamento das especiarias por radiação, o odor das mesmas sendo dissipado, sugerindo uma grande perda de compostos voláteis antes mesmo das análises.

- A dificuldade de se analisar sensorialmente as especiarias isoladamente é real, uma vez que expostas ao meio ambiente, é possível a perda da capacidade de detecção olfatória dos compostos emitidos. Porém, seria interessante uma avaliação quanto à capacidade de descontaminação microbiológica e a análise da capacidade de se manter uma melhor qualidade sensorial após o processamento por radiação ionizante. 


\section{REFERÊNCIAS BIBLIOGRÁFICAS}

Akgul, A., Kivanç, M. Inhibitory effect of selected Turkish spices and oregano components on some foodborne fungi. International Journal of Food Microbiology. 6: 263-268, 1988.

Aligians, N.; Kalpoutzakis, E.; Mitaku, S.; Chinou, I.B. Composition and antimicrobial activity of the essential oil of two Origanum species. J. Agric.Food Chem., 49: 4168-4170, 2001.

Almeida, A.P.G. Avaliação do processo de irradiação em especiarias utilizando a técnica de difração de Raios X, Universidade Federal do Rio de Janeiro COPPE, setembro, 2006.

Almeida, E. R. Plantas medicinais brasileiras. Ed. Hémus. São Paulo, SP. p. 294-6, 1993.

Arena V. In: Ionizing Radiation and Life. Mosby, St. Louis, 1971

Barroso, G. M; Guimarães, E . F ; Ichaso, C .L .F; Costa, C . G; Peixoto, A. L. Sistemática das Angiospermas do Brasil. Vol I. 1a ed. São Paulo, EDUSP, 225p., 1978.

Basílico, M.Z.; Basílico, J.C. Inhibitory effects of some spice essential oils on Aspergillus ochraceus NRRL growth and ochratoxin A production. Letters in Applied Microbiology. 29: 238-241, 1999.

Bedin, C., Gutkoski, S.B., Wiest, J.M. Atividade antimicrobiana das especiarias. Higiene Alimentar, v.13, n.65, p.26-9, 1999. 
Bendini, A.; Galina Toschi, T.; Lercker, G. Influence of gamma irradiation and microwaves on the linear unsaturated hydrocarbon fraction in spices. Zeitschrift für Lebensmittel Untersuchung und Forschung A, 207: 214-218, 1998.

Boisseau P. Irradiation and the food industry in France. Food Technology, 48: 138-140, 1994.

Brochini, C.B., Núñez, C.V., Moreira, I.C., Roque, N.F., Identificação de Componentes de óleos Voláteis: Análise Espectroscópica de Misturas de Sequiterpenos. Instituto de Química, Universidade de São Paulo, São Paulo, 1998.

Burg, I. C.\& P. H. Mayer. Alternativas ecológicas para prevenção e controle de pragas e doenças. Ed. Grafit. Francisco Beltrão, PR. p. 61-62, 1999.

Calucci, L.; Pinzino, C.; Zandomeneghi, M.; Capocchi, A.; Ghiringhelli, S.; Saviozzi, F.; Gallesgchi, L. Effects of gama irradiation on the Free Radical and Antioxidant Contentes in Nine Aromatic Herbs and Spices. J. Agric. Food Chem., 51 (4), 927-934, 2003.

CDC. Preliminary FoodNet data on the incidence of infection with pathogens transmitted commonly through food - Selected sites, United States. Morb. Mortal. Weekly Rep., 53(16): 338-343, 2004.

Cervato, C.; Carabelli, M.; Gervasio, S.; Cittera, A.; Cazzola, R.; Cestaro, B. Antioxidant properties of oregano [Origanum vulgare] leaf extracts. J. Food Biochem., 24: 453-465, 2000

Coe-Teixeira, B. Lauráceas do gênero Ocotea do estado de São Paulo. Rodriguésia, v. 32, n. 52, p. 55 - 190, 1980. 
Correa, M. P. Dicionário das plantas úteis do Brasil e das exóticas cultivadas. IBDF/MA. Brasília, DF. p. 475-7, 1984.

Cosetino, S.; Tuberoso, C.I.G., Pisano, B., Satta, M.; Mascia, V.; Arzedi, E.; Palmas, F. In-vitro antimicrobial activity and chemical composition of Sardinian Thymus essential oils. Letters in Applied Microbiology. 29: 130-135, 1999.

Costa, R.S.C.; Medeiros, I. M. Pimenta-do-reino, EMBRAPA Rondônia Folder, Porto Velho, 6p, 1997.

Crawford, L.M., Ruff, E.H. A review of the safety of cold pasteurization through irradiation. Food Control. V.7. pp87-97, 1996.

Cronquist, A. The Evolution and classification of flowering plants. 2 nd ed. New York, New York Botanical Garden, 517p ,1988.

Crowley, M.L., Gaboury, D. J., Witt, D. Chef's attitudes in North-Eastern US toward irradiation beef, Olestra, rBST and genetically engineered tomatoes. Food Service Technology, v. 2, p. 173-181, 2002.

Daferera, J.D.; Ziogas, N.B.; Polissiou, G.M. Gc-Ms analysis of essential oils from some Greeks aromatic plants and their fungitoxicity on Penicillium digitatum. Journal of Agriculture and Food Chemistry. 48: 2576-2581, 2000.

Delincee, H., Chemical and Biological Methods for the Identification of Irradiated Food. European School of Advanced Studies on Nuclear and ionizing Radiation Technologies: University of Pavia, Italy, 6p., April 2005.

Del Mastro, N.L., Development of Food Irradiation in Brazil, Progress in Nuclear Energy, vol.35, pp229-248, 1999. 
Diehl, J.F.,Food Irradiation past, present and future, Radiation Physics and Chemistry. V.63, pp.195-214, 2002

Diehl, J. F. Safety of Iradiated Foods. New York: Marcel Dekker, Inc, 345p., 1995.

Domans, H.J.D.; Deans, S.G. Antimicrobial agents from plants: antibacterial activity of plant volatiles oils. Journal of Applied Microbiology. 88: 308-316, 2000.

Editora Abril Guia Rural: o mundo das especiarias. São Paulo, SP. 133p., 1991.

El - Shami, M.A.; Fadil, F.A.; Sirry, A.R.; El-Zayat, M.M. Antifungal property of garlic, clove juice compared with fungicidal treatment against Fusarium with watermelon. Egyptian Journal of Phytopathology. 17: 55-62, 1985.

EMBRARAD , http://www.embrarad.com.br/alimentos acesso em 13 de agosto de 2003.

EPA - Environmental Protection Agency. History about food irradiation, United States General Accounting Office, http: www.epa.gov., acesso em: 15 junho 2008.

Esteves, M.P.G.C.S., Irradiação de Especiarias. Métodos de detecção do tratamento e estudo das alterações em que se baseiam. Tese de D.Sc, Universidade Técnica de Lisboa, Lisboa, Portugal, 1997.

Farkas J. Decontamination including parasite control of dried chilled and frozen foods by irradiation. Acta Alimentaria, 16: 351-384 1987.

Farkas, J. Irradiation as a method for decontamination food. A review. Intl. J. Food Microbiol., v. 44, p.189-204, 1998. 
Farrel, K.T. , Spices, Condiments and Seasonig, second edition, 414 pg - ISBN 0834213370, 1998

Farkas, J. Irradiation for better foods. Trends in Food Sci. \& Technol., v. 17, n. 4, p. 148-152, 2006.

Farrel, K.T. , Spices, Condiments and Seasonig, second edition, 414 pg - ISBN 0834213370, 1998.

Food Irradiation Watch. Comunication with Robin Taubenfeld, 2 nov., 2006

Food Standards Agency. Irradiated food supplements entoroement exercise published. Great Britain. 22 nov, 2006.

Food \& Water Watch, Status of Food Irradiation Around the World, Backgrounder, U.S.A, nov. 2006.

Fox J.A. Influence on purchase of irradiated foods. Food Technology, 56 (11): 34-37, 2002.

Fraipe, G. A. Myristica fragans, CEPLAC. Bahia, 2002.

Grecz, N.; Rowley, D.B.; Matsuyama, A. The action of radiation on bacteria and viruses. In: Josephson; E.S.; Peterson, M.S. (Ed.). Preservation of Foods by lonizing Radiation. Boca Raton: CRC Press. v.2, p.167- 218, 1983.

Henry, C.J.K., Chapman, C., The Nutrition Handbook for Food Processors". In: Ehlermann, D.A.E (ed), Irradiation, 1 ed., chapter 17, New York, USA, CRC Press LLC, 2002. 
Horváthová J., Suhaj M., Polovka M., Effect of Gamma Irradiation on Trichromatic Values of Spices. F. Res. Inst., Bratislava, Slovakia 2007.

IAEA, Irradiation of Spices, herbs and other vegetable seasoning. A compilation of technical data for its authorization and control, IAEA- TccDoc- 639, 1992.

ICGFI - GRUPO CONSULTIVO INTERNACIONAL SOBRE IRRADIAÇÃO DE ALIMENTOS (ICGFI). Fatos sobre a irradiação de alimentos. Ed. CDTN (Centro de Desenvolvimento da Tecnologia Nuclear), Brasil, 46pp, 1999.

IMIP - International Meeting on Irradiation Processing, Kuala Lumpur, Malaysia, Feb. 26 - March 3, 2006.

Jirovetz, L., Buchbauer, G., Ruzicka, J., Shafi, M. P., Rosamma, M.K. 2001. Analysis of Cinnamomum zeylanicum Blume leaf oil from south India. J. Essent. Oil Res., 13: 442-443.

Kivanç, M.; Akgul, A.; Dogan, A. Inhibitory and stimulatory effects of cumin, oregano and their essential oils on the growth and acid production of Lactobacillus plantarum and Leuconostoc mesenteroides. International Journal of Food Microbiology. 13: 81-86, 1991.

Koutsoumanis, K.; Lambropoulou, K.; Nychas, G.J.E. A predictive model for the non-thermal inactivation of Salmonella enteridis in a food model system supplemented with a natural antimicrobial. International Journal of Food Microbiology. 49: 63-74, 1999.

Leal, A.S., Krambrock, K., Rodrigues, R.R., Ressonância Paramagnética Eletrônica - RPE aplicada a análise de especiarias irradiadas (com radiação gama), Ciência e Tecnologia de Alimentos. V.24, PP.427-430, 2004. 
Lee, E.J.; Ahn, D.U. Production of Volatiles from Fatty Acids and Oils by Irradiation. J. Food Science, 68(1), 70-75, 2003.

Leung, A.Y.; Foster, S. Encyclopedia of common natural ingredients used in foods, drugs and cosmetics. $2^{\underline{a}}$ ed. New York: Wiley, p. 465-466, 1996.

Lima, K. S., Lima, C.; Grossi, J. L. S., Lima, A. L. S., Alves, P. F. M. P., Coneglian, R. C. C., Godoy, R. L. O., Sabaa-Srur, A. U. O. Efeito da irradiação ionizante y na qualidade pós-colheita de cenouras (Daucus carota L.) cv. Nantes, Ciênc. Tecnol. Aliment., Campinas, 21(2): 202, 208, maio-ago . 2001

Lima, M.P., Zoghbi, M.G.B., Andrade, E.H.A., Silva, T.M.D., Fernandes, C.S. Volatile constituents from leaves and branches of Cinnamomum Zeylanicum BLUME (Lauraceae), Acta Amazônica, Brasil, 2005.

Loaharanu P. Status and prospects of food irradiation. Food Technology, 52: 124-131, 1997.

Lobo, I. Brazil to use irradiation in fruits and vegetables for export, Brazil Magazine, July 12, 2006.

Marín, S.; Velluti, A.; Ramos, A.J.; Sanchis, V. Effect of essential oils on zearalenona and deoxinivalenol production by Fusarium graminearum in nonsterilized maize grain. Food Microbiology. 21: 313-318, 2004.

Marino, M.; Bersani, C.; Comi, G. Impedance measurements to study the antimicrobial activity of essential oils from Lamiaceae and Compositae. International Journal of Food Microbiology. 67: 187-195, 2001.

Marques, C.A. Importância econômica da família Lauraceae Lindl.,Floresta e Ambiente V. 8, n.1, p.195 - 206, jan./dez., 2001. 
MDS Nordion, http://www.mds.nordion.com , acesso em: 5 de agosto de 2006

MDS Nordion, http://www.mds.nordion.com , acesso em: 23 de julho de 2008

Milos, M.; Mastelic, J.; Jercovik, L. Chemical composition and oxidant effect of glicosidically bound volatile compounds from orégano (Origanum vulgare L. spp. hirtum).Food Chemistry. 71: 79-83, 2000.

Morsbach, N. Óleos essenciais de cascas e folhas de canela (Cinnamomum verum Presl) cultivada no Paraná. (IAPAR), Paraná, 1997.

Nayga R.M. Jr., Poghosyan A., Nichols J. Will consumers accept irradiated food products? International Journal of Consumer Studies, 28: 178-185, 2004.

Nawar, W.W. Lipids. In: FENNEMA, O.R. (Ed.). Food chemistry, 3.ed. New York: Marcel Dekker, p.225-319, 1996.

Nostro, A.; Blanco, A.R.; Cantelli, M.A.; Vicenzo, E.; Flamini, G.;Morelli, I., et al. Susceptibility of methicillin-resistant staphylococci to oregano essential oil, carvacrol and thymol. FEMS Microbiology Letters. 230: 191-195, 2004.

Novack, J.; Christina, B.; Langbehn, B.; Park, F.; Skoula, M.; Gorsiou, Y.; Franz, C.M. Ratios of cis- and trans- sabinene hydrate in Origanum marjorana L. and Origanum midrophyllum (Bentham). Bioch. Systematics and Ecology. 28: 697704, 2000.

Oliveira, L.C. Present situation of food irradiation in South America and the regulatory perspectives for Brazil. Radiat. Phys. Chem., v.57, p. 249-252, 2000. 
Ornellas, C.B.D.; Gonçalves, M.P.J.; Silva, P.R.; Martins, R.T. Atitude do consumidor frente à irradiação de alimentos, Ciênc. Tecnol. Aliment. v.26 n.1 Campinas jan/mar. 2006

Olson D.G. Irradiation of food. Food Technology, 52: 56-62, 1998.

Paster, N.; Juven, B.J.; Shaaya, E.; Menasherov, M.; Nitzan, R.; Weisslowich, H.; Ravid, U. Inhibitory effect of oregano and thyme essential oils on moulds and foodborne bacteria. Letters in Applied Microbiology. 11: 33-37, 1990.

Paster, N.; Menasherov, M.; Ravid, U.; Juven, B. Antifungal activity of oregano and thyme essential oils applied as fumigants against fungi attacking stored grain. Journal of Food Protection. 58: 81-85, 1995.

Peak, P.W.; Pussel, B.A.; Martyn, P.; Timmermans, V.; Charlesworth, J.A. The inhibitory effect of rosmarinic acid on complements involves the 5 convertase. Internacional Journal of Immunopharmacology. 13: 853-857, 1991.

Perez, L. H.; Freitas, B. B. de. Chá preto: estabilidade no mercado. São Paulo: IEA, 2003.Disponível em:<http://www.iea.sp.gov.br/out/verTexto.php?codTexto=791>. Acesso em: jun. 2007.

Philippi, J. M. S. \& Moretto, E. Salmonella and Fecal Coliforms in Cinnamon (Cinnamomum cassia Blume and Cinnamomum zeylanieum Nees) Sold in the City of Florianópolis, Santa Catarina, Brazil. Cad. Saúde Públ., Rio de Janeiro, 11 (4): 624-628, Oct/Dec, 1995.

Phytosan S.A., www.phytosan.com, acesso em: 5 de agosto de 2008. 
Radhakrishhhanan-Sridhar, S.; Velusamy-Rajaopal, R. Antifungal activity of some essential oils. Journal of Agriculture and Food Chemistry. 51: 75967599, 2003.

Rao, Y. R., Paul, S. C., Dutta, P. K. 1988. Major constituents of essential oils of Cinnamomum zeylanicum. Indian Perfum., 32: 86-89.

Razskazovskiy Y., Debije M.G., Howerton S.B., Williams L.D., Bernhard W.A. Strand breaks in X-irradiated crystalline DNA: Alternating CG oligomers. Radiation Resistance Research, 160: 334-339, 2003.

Rela, P.R. Engenharia de Alimentos, n. 6, p. 26-9., 2000.

Rela, P.R.; Calvo, Napolitano, C. M.; Kodama, Y.; Omi, N.M.; Costa, F. E. Programa de qualificação de um irradiador multipropósito de Cobalto-60 tipo compacto.IN: International Nuclear Atlantic Conference - INAC. 2005.

Resurreccion, A.V.A, Galvez, F.C.F., Fletcher, S.M., Misra, S.K. Consumers attitudes towards irradiated food: results of a new study. Journal of Food Protection, v. 58, n. 2, p. 193-196, 1995.

Ressurrecion, A.V.A., Galvez, F.C.F., Will consumers buy irradiated beef?, Food Technology, 53(3): 52-56, 1999.

Ristori, C.A.; Pereira, M.S.; Gelli, D.S. O efeito da pimenta do reino moída frente a contaminação in vitro com Salmonella rubislaw. Revista do Instituto Adolfo Lutz. 61:131-133, 2002.

Rodrigues, P.C., Branco, J.A. A análise de Componentes Principais sobre dados independentes, Faculdade de Ciência e Tecnologia, Universidade Nova de Lisboa, p 2/26, setembro 2006. 
Sádecká J. Irradiation of spices - a review. Czech J. FoodSci., 25:231-242, 2007

Sagdiç, O.; Kusçu, A.; Ozcan, M.; Ozçelic, S. Effects of Turkish spices extracts at various concentrations on the growth of Escherichia coli 0157:H7. F. Microb. 19: 473-480, 2002.

Sahin, F.; Gulluce, M.; Daferera, D.; Sokmen, A.; Sokmen, M.; Polissiou, M. Food Control. 56: 2-9, 2003.

Sanz; E. Irradiação de alimentos pode aumentar exportacoes de frutas brasileiras. Disponível em: www.radiobras.gov.br/ct/1996/materia 270996 12.htm>. Acesso em: 5 de maio de 2008.

Secretaria de Agricultura do Estado de São Paulo. Instruções agrícolas para o Estado de São Paulo. Ed. IAC. Campinas, SP. p. 170-71, 1987.

Senanayake, U. M., Lee, T. H., Wills, R. B. H. Volatile constituents of cinnamon (Cinnamomum zeylanicum) oils. J. Agric. Food Chem., 26: 822-824, 1978.

Smith, J.S.; PILLAI, S. Irradiation and Food Safety. Food Technol., v. 58, n. 11, p. 48-55, 2004.

Sivropoulou, A.; Papanikolau, E.; Nicolau, C.; Kokkini, S.; Lanaras, T.; Arsenakis, M. Antimicrobial and citotoxic activities of Origanum vulgare essential oil. J. Agric. F. Chem. 44; 1202-1205, 1996.

Souza, E. L., Stamford, T.L.M. , Lima, E.O. , Trajano, V.N. , Filho, J.M.B. , Antimicrobial effectiveness of spices: na approach for use in food conservation systems , Braz. arch. biol. technol. vol.48 no.4 Curitiba, Food Science and Technology,Julho 2005. 
Tauxe, R.V. Food safety and irradiation: Protecting the public from foodborne infections. Emerg. Infect. Dis., v. 7, n. 3, p. 516-521, 2001.

Tébéka, I.R.M.; Hallwass, F., Radiações Nucleares: Histórico e Aplicação Industrial na Preservação de Alimentos, I Congresso Norte Nordeste de Química, Universidade Federal de Pernambuco - Departamento de Química Fundamental, 2007.

Thayer D.W., Josephson E.S., Brynjolfsson A., Giddings G.G.Radiation Pasteurization of Food. Council for Agricultural Science and Technology CAST. Ames, Apr. 1996

Thomas, J., Greetha, K., Shylara, K. S. Studies on leaf oil and quality of Cinnamomum zeylanicum. Indian Perfum., 31: 249-251, 1987.

Tjaberg T.B., Underdal B., Lunde G. The effect of ionizing radiation on the microbial content and volatile constituents of spices. Journal of Applied Bacteriology, 35: 473-478, 1972.

USDA News Released. International Meeting on Irradiation Processing, Kuala Lumpur, Malasia, 26 fev.- 3 marc., 2006

Velutti, A.; Sanchis, V.; Ramos, A.J.; Egido, J.; Marín, S. Inhibitory effect of cinnamon, clove. lemongrass, oregano and palmarose essential oils on growth and fumonisin B1 production by Fusarium proliferatum in maize grain. International Journal of Food Microbiology. 89: 145-154, 2003.

Weeb, M., Penner, K.P., Food Irradiation, Department of Animal Sciences and Industry, Extension Especialist, Food Science, 2000. 
Werff, H. Wan Der \& Richter, H. G. Toward and improved classification of Lauraceae. Annals of the Missouri Botanical Garden, v. 8, p. 419 - 432, 1996.

WHO, High-dose irradiation: Wholesomeness of food irradiated with doses above 10 kGy. Report of a joint FAO/IAEA/WHO study group. WHO Technical Report Series 890. World Health Organization, Geneva 1999.

Zargari, A. Medicinal Plants. $4^{\underline{a}}$ ed. Tehran: Tehran University Publications. p.42-45, 1990. 